\title{
WestVirginiaUniversity
}

THE RESEARCH REPOSITORY @ WVU

Graduate Theses, Dissertations, and Problem Reports

2008

\section{Mobilizing movements, mobilizing contemporary Islamic resistance}

Rachael M. Rudolph

West Virginia University

Follow this and additional works at: https://researchrepository.wvu.edu/etd

\section{Recommended Citation}

Rudolph, Rachael M., "Mobilizing movements, mobilizing contemporary Islamic resistance" (2008). Graduate Theses, Dissertations, and Problem Reports. 4418.

https://researchrepository.wvu.edu/etd/4418

This Dissertation is protected by copyright and/or related rights. It has been brought to you by the The Research Repository @ WVU with permission from the rights-holder(s). You are free to use this Dissertation in any way that is permitted by the copyright and related rights legislation that applies to your use. For other uses you must obtain permission from the rights-holder(s) directly, unless additional rights are indicated by a Creative Commons license in the record and/ or on the work itself. This Dissertation has been accepted for inclusion in WVU Graduate Theses, Dissertations, and Problem Reports collection by an authorized administrator of The Research Repository @ WVU.

For more information, please contact researchrepository@mail.wvu.edu. 
Mobilizing Movements, Mobilizing Contemporary Islamic Resistance

\title{
Rachael M. Rudolph
}

Dissertation submitted to the Eberly College of Arts and Sciences at West Virginia University in partial fulfillment of the requirements

for the degree of

\section{Doctor of Philosophy in}

Political Science

Scott Crichlow, Ph.D, Co-Chair Jeffrey Worsham, Ph.D Co-Chair Joe Hagan, Ph.D

Robert Duval, Ph.D

Abdul Karim Bangura, Ph.D

Department of Political Science

\author{
Morgantown, West Virginia \\ 2008
}

Keywords: Social Movements, Islamic Resistance, Mobilization

Copyright 2008, Rachael M. Rudolph 


\section{ABSTRACT \\ Mobilizing Movements, Mobilizing Islamic Resistance \\ Rachael M. Rudolph}

Recent world events, ranging from international violence to elections, have propelled academics and policymakers to examine Islamic resistance movements more closely. Previous studies of such movements, in both the English and Arabic literature, has been limited to historical case studies. The lack of systematic cross-case comparisons has limited the development of generalizable propositions regarding movement mobilization. In a first effort to remedy this gap in the literature, this study examines the mobilization of Islamic resistance movements - the FIS, the PIJ, Hamas, the MNLF, the MILF and the ASG-in three different countries located in three different regions. Mobilization was examined utilizing the American and European paradigms within the social movement literature. The American paradigm emphasized the role of activists for mobilization, whereas the European paradigm emphasized identity. The central goal of the study is to answer the following: Do Islamic resistance movements share common mobilization characteristics? 


\section{Dedicated to:}

Issa $M$.

A special person, one like none other...

Forever in our hearts and always through our endeavors you will remain.

I will never forget, Insha'Allah. 


\section{Acknowledgements}

I am grateful to many who provided assistance and support during the arduous writing process. Special thanks go first and foremost to my dissertation committee members, Drs. Jeffrey Worsham, Scott Crichlow, Robert Duval, Joe Hagan and Abdul Karim Bangura. I extend a special thank you to Drs. Worsham and Crichlow for having read and commented on countless drafts of the dissertation prior to the defense and afterward who read and commented on the chapters once more before it was finally complete; to Drs. Duval and Bangura for providing me with encouragement and support when I would have preferred to cry; and, to Dr. Hagan for being understanding and having faith that I would finish.

Second, I would like to say thank you to my daughter and family for putting up with my many different moods, for never complaining about the long days and nights or taking over the entire first floor with documents, drafts, etcetera and for their love and encouragement.

Third, I would like to thank my friends, in particular Jen Anderson, Kyle and Sam Christensen, Said Abdelwaheed, and Marwan Fararjeh. I would not have made it sanely through some nights without Jen and Said sending me messages of encouragement via instant messenger or e-mail; sometimes I think Jen intentionally stayed awake with me until 5am in the morning just to be there in case she was needed.

Fourth, I would like especially to thank Donna MacIsaac for being there when I needed someone to listen, to rant about the comments or the revisions that needed to be made, and to provide advice. She was there for me when I was finishing the book for Ashgate and then again for the dissertation. Donna was like a second mother throughout my entire tenure at West Virginia University.

Finally, I would like to thank my dearest friend, David Mastro, for making me laugh when I wanted to cry and for providing me with direction when I was directionless. 


\section{Table of Contents}

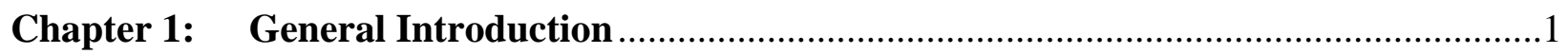

Theories of Collective Action.....................................................................................

The American Paradigm ..................................................................................................

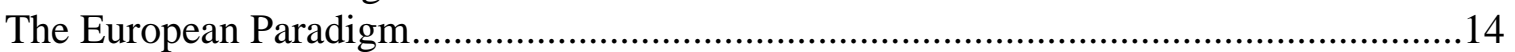

The Integrative Approach …………...........................................................................17

Summary of the Theoretical Paradigms............................................................................22

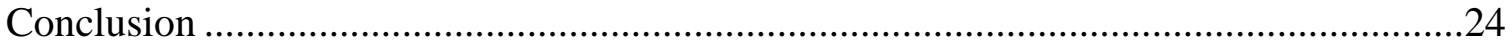

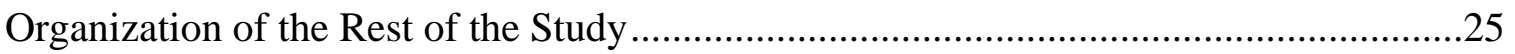

Chapter 2: Research Design and Method: Comparing Mobilizations of ...........................26 Contemporary Islamic Resistance Movements

The Comparative Case Study Approach.........................................................................26

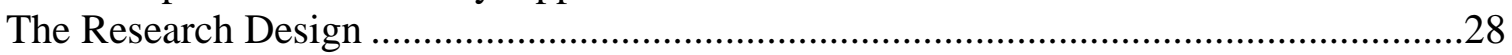

Movement Mobilization from the American Paradigm........................................................30

Movement Mobilization from the European Paradigm ........................................................35

Data Collection for Mobilization ...................................................................................38

Comparing Islamic Resistance Movements’ Mobilizations ................................................40

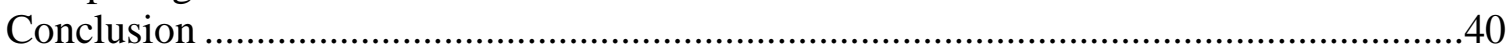

Chapter 3: Mobilizing the Islamic Salvation Front.........................................................41

Brief History of Algeria from French Colonization to Independence (1830-1962) ...........41

FIS Mobilization from the American Paradigm ...............................................................46

Socio-Economic Crises, Deprivation and Structural Differentiation ................................47

Political Opportunities ..................................................................................................51

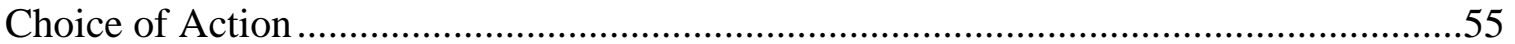

Mobilization from the European Paradigm.....................................................................55

Conflict and Cleavages ............................................................................................56

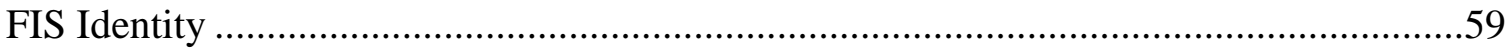

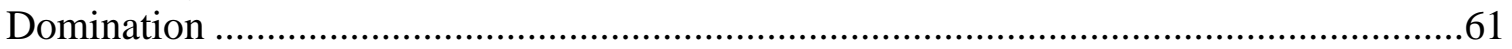

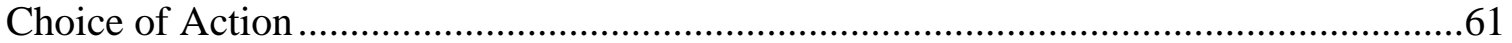

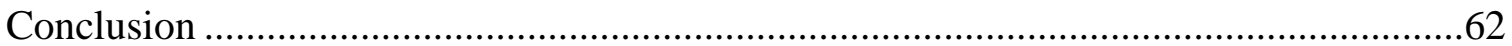

Chapter 4: Mobilizing the Islamic Jihad Movement and the Hamas..................................64

Brief History of Palestinian National Consciousness ........................................................64

Mobilization from the American Paradigm .....................................................................72

Socio-Economic Crises, Deprivation and Structural Differentiation ................................73

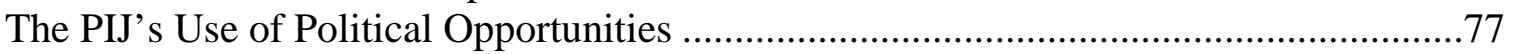

Hamas' Use of Political Opportunities .........................................................................79

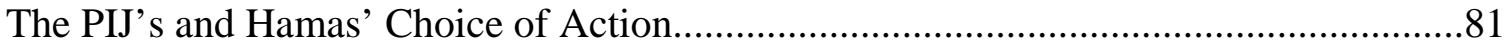

Mobilization from the European Paradigm...................................................................82

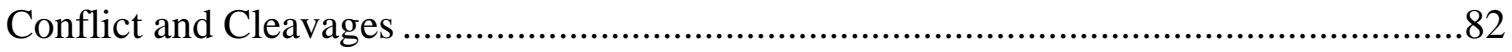

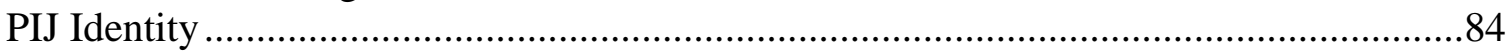

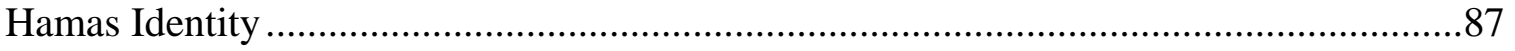

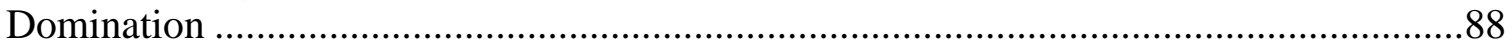




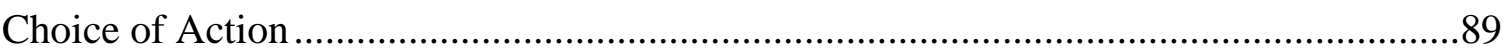

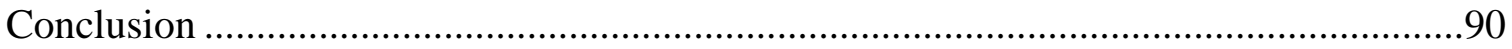

Chapter 5: Mobilizing the Moro National Liberation Front, .............................................91 the Moro Islamic Liberation Front and Abu Sayyaf's Group

History of the Philippines and Muslim Separatism ..............................................................91

Mobilization from the American Paradigm .....................................................................97

Socio-Economic Crises, Deprivation and Structural Differentiation ...............................98

The MNLF's Use of Political Opportunities ...........................................................104

The MILF's Use of Political Opportunities ......................................................................105

The ASG's Use of Political Opportunities........................................................................106

The MNLF's, the MILF's, and the ASG'S Choice of Action ..........................................107

Mobilization from the European Paradigm....................................................................108

Conflict and Cleavages ...............................................................................................108

The MNLF Identity ....................................................................................................110

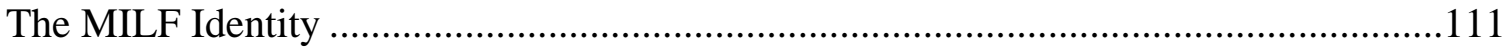

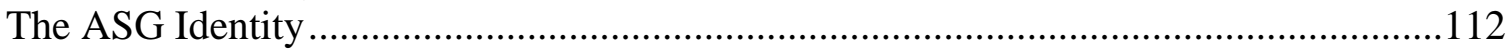

Domination and Choice of Action ..............................................................................113

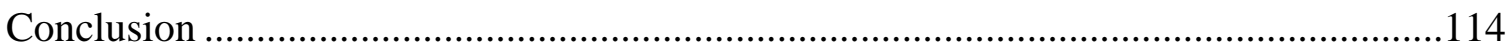

Chapter 6: General Conclusion: Comparing Contemporary ……………………..........115 Islamic Resistance Movements

Mobilization of Islamic Resistance from the American Paradigm....................................115

Mobilization from the European Paradigm......................................................................121

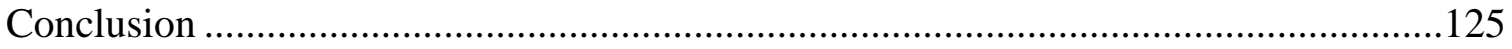

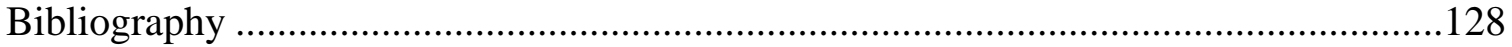

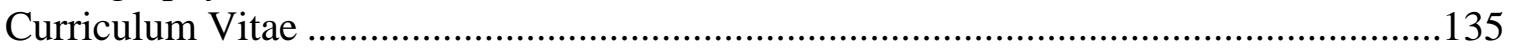




\section{List of Tables}

Table 1.1 The American and European Movement Mobilization Framework .....................24

Table 2.1 Explaining Mobilization from the American Paradigm......................................31

Table 2.2 Explaining Mobilization from the European Paradigm .....................................36

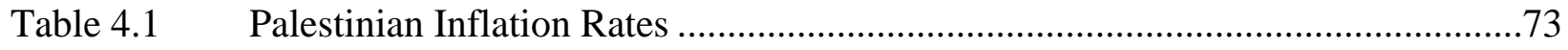

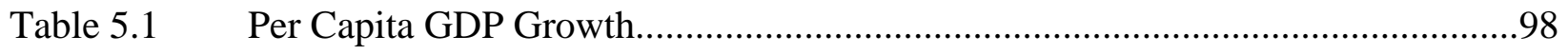

Southeast Asian Countries, 1950-1995 (\%)

Table 6.1 Mobilization of Islamic Resistance Movements...............................................117 from the American Paradigm

Table 6.2 Mobilization of Islamic Resistance Movements...............................................122 from the European Paradigm 


\section{Chapter 1}

\section{General Introduction}

Islamic resistance movements engaged in both violent and non-violent protest have

existed from the $7^{\text {th }}$ Century to the present. While their emergence is nothing new, recent world events ranging from international violence to elections have propelled academics and policymakers to examine them more closely. The majority of the literature on these movements examine them within a given country on a case-by-case basis, providing a detailed historical analysis (Bodansky, 2007; Levitt, 2006; Harik, 2004; Mishal and Sela 2000). Similarly, the Arabic literature has also emphasized case-by-case historical analysis of resistance movements (Al-Hamad and Al-Barghuthi, 1997; Al-Barghuthi, 1990; Bin Yusuf, 1989). Even the Arabic literature that provides strategies or methods for developing an Islamic resistance movement is geographically limited and does not provide general propositions regarding mobilization across cases (Azzam, 1987; Mawdudi, 1973; Qutb, 1967). A lack of systematic cross-case comparisons of Islamic resistance movements within and across the geographical locations selected prohibits the development of generalizable propositions regarding movement mobilizations.

Do Islamic resistance movements share common mobilization characteristics? Movement mobilization has been widely studied in the American and European literature, with studies focusing on those mobilizing in the United States, Europe, South Africa or Latin America. They have rarely been studied in the Middle East, North Africa and Southeast Asia. Movements are defined as a form of association, as collective challenges by people with common purposes and solidarity in sustained interaction (Goodwin and Jasper, 1999; Tarrow, 1994). These forms of association are concerned with the appropriation and orientation of social 
values and resources which transgress institutionalized norms (Vahabzadeh, 2001; Melucci, 1980). Thus, they are action-based systems operating in a systemic field of opportunities (Vahabzadeh, 2001; Melucci, 1985). Movements use differing means, ends and forms of solidarity and organization that converge in a more or less stable manner, which produce unity (Carroll and Hackett, 2006; Melucci, 1989). The formation or mobilization of movements, according to movement scholars, is a form of protest, a declaration of disagreement, dissent, objection and unwillingness to comply (Yiftachel, 1997; Lofland, 1985). It is the most common form for fomenting change, which ranges from rhetoric to violence (Yiftachel, 1997; Herman, 1995). This study is concerned with the mobilization of Islamic resistance movements engaged in both non-violent and violent forms of protest.

Existing movement mobilization literature fails to examine the emergence of Islamic resistance movements from within social movement theory (Simsek, 2004). Simsek, however, does examine Islamic socio-cultural and political organizations in Turkey, but not Islamic resistance movements. In his study, Simsek posited that Marxism or post-Marxism was irrelevant to Islamism, which is both an old and new movement based on theoretical criteria. Islamism in Turkey was a post-modernist movement that perceived the modernization process and its associational phenomenon, such as secularism, as highly repressive of its system of values and other major projects such as the Islamic way of life and its own understanding of civilization (Semsek, 2004: 120-124).

Islamism in Turkey, Simsek argues, is also very much a post-traditionalist movement because it critiques and reinterprets traditional faith, which is a major part of Islamic revivalism. It both transforms the "passive” tradition by emphasizing and making visible several aspects in the public sphere in order to enhance and restructure the latter, and tries to formulate its own 
modernity through hybridization between the revived tradition and modernity. It is primarily middle-class based, but receives support from lower socio-economic classes and the politically disenfranchised. It is also a post-material and identity-oriented movement, raising symbolic issues and demanding religious and cultural recognition in the public sphere, which attempts to create an Islamic identity and way of life. Specifically, in Turkey, it began as a reactive movement but gradually became a proactive social movement by raising diverse issues, pursuing goals concerning the present and every day life. The movement is highly centralized at the political level, but decentralized at the civil society level (Semsek 2004: 120-124).

Simsek's analysis is limited because it is restricted to within country comparisons. This type of comparative analysis does not permit the deduction of evidence for the generalizable claims posited by both the American and European paradigms. This study, therefore, builds on Simsek's work by examining Islamist movements in Algeria, Palestine and the Philippines. It differs because it examines movements that have arisen in different geographical locations, at different times, and that employ differing forms of protest. Emphasis on movement mobilization, with spatial and temporal differentiation and forms of protest, permits the formulation of more generalizable propositions regarding mobilization of contemporary Islamic resistance that would not otherwise be observable by a single case-by-case study.

Moreover, with the exception of Simsek, social movement scholars do not examine the emergence of Islamic movements from within social movement theory. Likewise, Islamic resistance scholars fail to examine the emergence of Islamic resistance movements from within social movement theory (Bodansky, 2007; Levitt, 2006; Harik, 2004; Mishal and Sela, 2000). This study, therefore, seeks to bridge that gap. It seeks to examine the emergence of Islamic resistance movements from within social movement theory. In particular, it seeks to examine 
Islamic resistance movements in Algeria, Palestine and the Philippines that use differing means, ends and forms of solidarity. Not only have Islamic movements been neglected by social movement scholars, but so too have the regions in which this study is concerned. Moreover, by examining six movements within three different countries, it will add to the existing literature on Islamic movements, which is confined to case-by-case and country specific studies. Moving beyond the case-by-case, country specific studies will aid in the construction of shared mobilization characteristics; and, it will aid in the development of generalizable propositions regarding these movement mobilizations.

Given that this study is rooted in social movement theory, the remainder of this chapter will examine the existing theoretical traditions from the pre to post-1970 periods. The pre-1970 period provided the foundation for two theoretical paradigms that have come to dominate contemporary social movement literature. The post-1970 period is bifurcated into two camps1) the American and 2) the European (Edelman, 2001; Joppke, 1991; Rochon, 1990). The American paradigm is strategy oriented, which posits that mobilization is the product of movement activists strategically using political context and grievances. The European paradigm posits that mobilization is a product of the social environment creating shared identities among movement activists. Polarization of scholarship into these two camps has resulted in calls for an integrated approach (Edelman, 2001; Vasi, 2006; Semsek, 2004). This study reiterates the call for an integrated approach, utilizing elements of the American and European paradigms to explain mobilization of contemporary Islamic resistance in three countries.

\section{Theories of Collective Action}

Theories of collective action have undergone a number of paradigmatic shifts over the years (Edelman, 2001). From the 1920s to the early 1970s, social organization was juxtaposed 
with collective behavior, wherein movements were seen as symptoms of societal deprivations, mass responses to economic crises, and charismatic leaders with mob mentality (Edelman, 2001; Park, 1967; Arendt, 1951). The collective behavior perspective, associated first with the works of LeBon (1930) and early Gurr (1970), emphasized movements' organization, tactical sophistication, reliance on privileged portions of the population, and use of mainstream channels of communication and fund-raising (Rochon 1990). According to the collective behavior perspective, movements were a reaction to deprivation.

Studies using this theoretical framework indicated that conditions of economic and/or political deprivation led to the emergence of movements (Champagne, 1983). Social deprivation was defined as widespread dissatisfaction with socio-cultural institutions, which were perceived as inadequate to provide ordinary satisfaction (Champagne, 1983; Barbar, 1941). Other studies also emphasized conditions of absolute and social deprivation (Thorton, 1981; Carroll, 1975; Barbar, 1941). The problem with many of these studies is that deprivation was viewed as the sole cause for mobilization and collective action; structural differentiation was not taken into consideration or factored into analyses of causality.

Champagne (1983) demonstrated that the emergence of movements was a product of both widespread perception of deprivation and structural differentiation. Structural differentiation is a process whereby a structure or institution differentiates into two or more structures or institutions that are structurally distinct from each other, but taken together function as a whole (Rueschemeyer, 1977; Smelser, 1959). Studies coupling both posited that more structurally differentiated societies had greater capacities for institutionalizing change than less structurally differentiated societies (Champagne, 1983; Eisenstaedt, 1978, Parsons, 1971 and 1966). That is, in societies where greater structural opportunities for movement participation existed, there was 
less likelihood for such groups to work outside of existing institutionalized boundaries. In contrast, less structurally differentiated societies did not allow for institutionalized expansion, which permitted inclusion of movement participation. Less structural differentiation, moreover, exacerbated perceptions of and actual deprivation. This, juxtaposed with the inability of societies to institutionalize change, aided in creating societal conditions necessary for mobilization (Champagne, 1983). For example, in societies wherein contemporary Islamic resistance movements emerged there was a perception among inhabitants of deprivation and limited structural differentiation. However, as will be demonstrated in this study, they are not the only variables contributing to movement mobilization.

Theoretically, Olson (1965), according to Edelman (2001), marked a point of departure in the collective behavior perspective. Rejecting irrationality, Olson posited that collective action was explained by the sum of strategic decisions of individuals not enticed by incentives or sanctions. The problem, according to Edelman, was that individuals, knowledgeable of severe risks, continued to participate in mass movements. For contemporary Islamic resistance movements, individuals were also aware of the risks associated with participation, but chose to do so regardless of the consequence. Moreover, the risks assumed were both collective and individual in nature and varied according to degree. For example, in contemporary Islamic resistance movements, a member of the information bureau assumes less of a personal risk than a member in the military bureau. However, they both share collective liability for movement action.

The collective behavior perspective was also challenged by Marxist-oriented explanations. Marxism, in contrast, defined movements and collective action as revolving around the fundamental contradiction between class interests and historical agency derived from 
class position (Edelman, 2001; Thompson, 1971). The problem, according to Edelman, was that movements were largely comprised of individuals from the middle-class and had multi-class constituencies. For contemporary Islamic resistance movements, this was also true. Although Islamic in nature, movements had populist agendas and constituencies from all socio-economic classes and multi-class constituencies. Moreover, they continue to be populist in nature and comprised of multiple socio-economic classes, with multi-class constituencies.

The collective behavior approach and Marxist critiques thereof provided a foundation for the theoretical paradigms that emerged in the 1970s. While there was a lack of theoretical generalization, two distinct paradigms emerged-1) the American and 2) the European (Edelman, 2001; Cohen, 1985; Della-Porta and Diani, 1999; Foweraker, 1995; Garner, 1997; Larana et al., 1994; McAdam, 1996). These paradigms, although not schools, were differentiated enough to constitute two distinct theoretical trends (Edelman, 2001). The American paradigm consisted of resource mobilization theory, political opportunity structures, and political process theory, with the latter dominating the field after the 1990s. The European paradigm, concerned primarily with identity politics, consisted of new social movement theory, which was referred to as popular movement theory in its application outside of America and Europe. Both the American and European paradigms are examined in the following subsections.

\section{The American Paradigm}

Rooted in the collective behavior perspective, but challenged by the European paradigm, the American paradigm consisted of varying theoretical frameworks. The American paradigm, with all its varying theoretical frameworks, is strategy oriented and analyzes material, human, cognitive, technological, and organizational resources that movements employ to expand, reward participants, and gain a stake in the political and social system (Edelman, 2001; Cohen, 1985). 
The American paradigm departed from the European paradigm over the why and how of movements. It criticized the European paradigm for being unable to explain how movements arose in particular times and places. This led American theorists to deviate from their own theoretical tradition and to emphasize resource mobilization theory (Edelman, 2001; McAdam et al., 1996; Zald, 1992; McCarthy and Zald, 1977).

Resource mobilization theory, concerned with resource availability and preference structures rather than the structural bases of social conflict, regards collective action as interest group politics by socially connected groups rather than by those most disenfranchised (Edelman, 2001). The problem with the collective behavior perspective, according to these theorists, was that movements were often times spontaneous uprisings against desperate circumstances (Rochon, 1990). Resource mobilization deemphasized deprivation and political grievances and emphasized the combination of political opportunities with the mobilization of individual and institutional resources. This combination sparked movement emergence. Movements, therefore, were seen as deliberate strategies of mobilization, backed by organizational and political resources (Rochon, 1990).

An outgrowth of the resource mobilization approach was an emphasis on issues capable of mobilizing people to action (Klandermans, 1989). These studies argued that shifts in public issue-attention led to the rise and decline of movements (Joppke, 1991). Examining the antinuclear movements in West Germany and the United States, Joppke demonstrated that shifts in public attention contributed to both the rise and decline of movements due to their feeding on cultural motifs and competition among one another for scarce resources. The rise of movements was therefore dependent on the societies' attention to social and political issues. The elevation of both issues resulted in movements similarly concerned becoming salient. As a result, 
competition emerged. Movements competed for status and power, which were exacerbated when they lacked a well-defined constituency and, thus, depended more on public attention to the issues addressed.

The decline of movements occurred when issues were no longer externally addressed, which resulted in the loss of prominence in politics and culture; and, when movements' goals were realized and, when the general motif, which fields an issue, shifted to a related yet distinct issue (Joppke, 1991). The latter factor, according to Joppke, led to the rise of parallel movements. The question that arises is whether a movement actually declines or shifts to correspond with public attention. While shifts in attention do affect the rise and decline of movements, the argument failed to consider that if there were no ideological conflicts with the attendant goals, then there would be evolution rather than the decline and creation of a new movement. $^{1}$

Another outgrowth of resource mobilization was an emphasis on a reliance of linkages between individuals, organizations and institutions in the establishment of movements (Rochon, 1990). The emphasis on the role of linkages for movement mobilization has demonstrated that contact between individuals, organizations, institutions, and movements must be abundant when the more marginal the clientele. Linkages were necessary for movements to be sustained, as their decline was a product of not sustaining contacts or linkages. Linkages, moreover, blurred the line between movements and established political channels such as political parties and interest groups. $^{2}$

\footnotetext{
${ }^{1}$ See Rudolph and Van Engeland (2008) regarding the role of ideological conflicts resulting in the decline or demise of movements and ideological evolution in the absence of such conflicts.

${ }^{2}$ See Rudolph and Van Engeland (2008) for the importance of linkages to movements in a globalized world of both domestic and international politics.
} 
Due to the lack of emphasis on the relationship between the state and movements by resource mobilization theorists, a new theoretical approach emerged-that is, Political Opportunity Structures (Rochon, 1990). This theory contended that mobilization was a function of the changes in the level of elite receptivity to protest, changes in elite ability and willingness to repress movements, and the presence of elite allies. Thus, political climate, independent of movement mobilization, strongly affected the potential outcomes of movements. Therefore, political context mattered most for mobilization (Edelman, 2001; Tarrow, 1998; Rochon, 1990).

Scholars within the political opportunity structure framework were concerned with the internal dynamics of movements, movement strategizing in the context of the balance of opportunity threats for challengers, and facilitation or repression by authorities (Edelman, 2001; Tarrow, 1998). The relationship between the state and movement were heavily emphasized. Interaction between the movement and state, according to Rochon (1990), could be both direct and indirect and strategies of interactions were both confrontational and collaborative. The balance between the two often depended on political context. The more centralized the state, the more conflictual the relationship. While Rochon argued it was interactions and not group rhetoric that needed to be studied, there is need for both, as group rhetoric serves as a signal to those it is directed. Political opportunity structure theory gives little attention to the discursive aspects of movements; it failed to recognize the social construction of political opportunity structure itself and ignored its local and international aspects (Edelman, 2001; Abdulhadi, 1998).

Related herein and to the aforementioned were studies viewing the viability and efficacy of movements as outcomes of interactions between internal and external factors (Hermann, 1992; Zald and Ash, 1996). Internal factors included institutionalization processes, changes in leadership, and ideological flexibility. External factors included changing social conditions that 
either strengthen or weaken the political support of movements, signals sent by society as a whole on the attainability of a movement's goals, and the presence or absence of other movements. A study conducted by Hermann (1992) on contemporary peace movements found that success and failure of movements were the outcome of their conscientious efforts to respond effectively to both internal and external demands, to have political impact, and at the same time to sustain their original raison d'être. It also demonstrated that aspirations to gain political significance and mass legitimation, through ideological modifications, also had undesirable results such as perceptual ambiguity, internal divisions, and loss of external credibility. The consequence was that movements fell short of realizing their potential (Hermann, 1992).

Yet, if the organizational structure underlying a movement contains mechanisms to prevent public displays of perceptual ambiguity, internal divisions and loss of external credibility, then it would not fall short of realizing its potential. Not actually ideological modification occurs but rather ideological evolution. Ideological shifts are necessary and successful when movements have internal mechanisms within their organizational structure to prevent fragmentation (Rudolph and Van Engeland, 2008). Moreover, both ideological shifts and organizational mechanisms to prevent fragmentation permit evolution. Thus, movements are able to both maintain and gain greater political significance and mass legitimation.

By the late 1990s, proponents of political opportunity structures came to see the theory’s contributions as one element in a broader political process, which included greater emphasis on the cultural-historical sources of discontent, protest, and mobilization (Edelman, 2001). This shift in theory gave way to political process theory, which has continued to dominate the American paradigm since the end of the 1990s (Edelman, 2001; Giugni, 1999). Like political 
opportunity structures, political process theory was concerned with the political environment in which movements emerged, in particular the external environment (Goodwin and Jasper, 1999; Meyer, 1999). Adopting the political opportunity thesis, political process theory posited that movements emerged because of expanding political opportunities; and, once they had emerged, movements would continue to expand such opportunities (Goodwin and Jasper, 1999; Tilly, 1994). The political process thesis added organizational and cultural factors to political opportunity. It posited that movements emerged when expanding political opportunities were seized by individuals, who were both aggrieved and optimistic about redressing their grievances (Goodwin and Jasper, 1999).

Studies herein emphasized how external opportunity structures, governing crises, and state structures supported or obstructed the process of collective action (Goodwin and Jasper, 1999; Edelman, 2001). This emphasis on the external was largely due to the argument that the world outside of movements led to movement mobilization. Some scholars, however, have recognized that opportunities do not cause mobilization. Rather, opportunities are a part of a multitude of factors that create the necessary conditions. Having the needed conditions also depended on individuals making strategic choices, intentionally taking advantage of that which they had at hand. Movements were required to make choices regarding language, claims, and opponents; they were also constrained by what they could say and do, the experiences of participants and those who they were attempting to mobilize (Meyer, 1999; Tarrow, 1992).

Movements did not choose goals, strategies, and tactics in a vacuum (Meyer, 1999). Rather, goals, strategies and tactics were chosen because they became more attractive and efficacious in a political context that shaped grievances. The result is that some claims are advantaged over others, subject to constraints associated with the structure of the governance 
system and the location of key actors such as political allies (Meyer, 1999; Tarrow, 1992). Political context, whether there is greater or less openness/access, provided specific opportunities (Meyer, 1999; Tilly, 1978; Eisenger, 1973). Choice, then, is understood through examination of resources available to movements, the venue in which they were employed, and the belief of participants that the goals, strategies and tactics were necessary and effective (Meyer, 1999).

Goals, strategies and tactics were further conditioned by cultural factors, as actions are suspended in symbolic webs of meaning (Goodwin, 1994). Symbols are signs that have meaning and significance through their interpretations, which produces patterns of relations or culture. Culture, thus, is patterned and patterning; it is enabling as well as constraining; and, it is observable in linguistic practices (Polletta, 1999). As was previously mentioned, political process theory incorporated cultural factors with explanations of movement mobilization, which resource mobilization and political opportunity structures failed to incorporate (Polletta, 1999; Johnston and Klandermans, 1995). The addition of cultural factors to the American paradigm is largely due to the critique by new social movement theorists of resource mobilization and political opportunity structures.

For theorists herein, structure was cultural. That is, according to Polletta (1999), culture was not the cause of but, rather, mediated between objective political opportunities and objective mobilization (McCarthy, McAdam and Zald, 1996; McAdam, Tarrow and Tilly, 1997). Moreover, culture constrained action as far as it impeded the capacity to perceive the system's objective vulnerability (Polletta, 1999). Differing political opportunity structures reflect differing public conceptions of the scope and role of the state (Polletta, 1999; Gamson and Meyer, 1996). Conceptions or perceptions influence opportunities for different forms of protest (Polletta, 1999; Della Porta, 1996). Traditions, principles, codes and arrangements are structural 
in the sense that they are symbolic; they are ways of ordering reality, which operate in the sphere of institutional politics (Polletta, 1999).

Culture, therefore, recognizes the social dimensions of political structures and processes and not only affects structure, but also opportunity. It plays an important role in creating opportunity. As was previously mentioned, the American paradigm's emphasis on culture stemmed from the new social movement theory's critique. New social movement theorists differed from political process theorists in the American paradigm over the role of culture and identities. Identity was not seen as a mediating cultural practice; the relationship was seen by new social movement theorists as being more complex (Vahabzadeh, 2001).

\section{The European Paradigm}

New social movement theory viewed contemporary movements as mirrors of conflicts found in the social and political structure of society (Rochon, 1990). The new movements were seen as uncovering issues excluded by and from political discussions such as sexuality, gender, and the environment, to name just a few (Vahabzadeh, 2001). Theorists within this paradigm emphasized the social status of the movement's activists and ideological justifications of their demands (Rochon, 1990) and focused on struggles over symbolic, informational and cultural resources and rights to specify differences (Edelman, 2001). Touraine (1988), among the first and most prolific advocates, posited that social movements have two dimensions (Edelman, 2001). Central to the first dimension was the notion of societal conflict, which created new identities, due to the presence of social cleavages. The second dimension is that diverse collectivities had the capacity to act on and struggle for historicity. Due to both dimensions, the "way of life" became the point of social contention and the struggles to effect relations of social domination were social movements. 
Touraine’s student, Albert Melucci, coined the term "new social movement theory" (Vahabzadeh, 2001). Melucci (1989) deemed identity the cardinal characteristic that distinguished new movements from the past. He argued that movements had three dimensions, not two, as Touraine claimed. First, there was recognition among actors of commonalities and shared identities, objectives, and understandings. Second, adversarial relations emerged with opponents competing for the same goods and values. Finally, change occurred when actions exceeded tolerated limits of the social system (Vahabzadeh, 2001). Identity or the construction of "we" by a group of individuals emerged through common orientations organized around three axes (Vahabzadeh, 2001). First, the relation of actors to the ends of their action provides direction. Second, the relation of actors to the means through which the action is carried out illustrates the possibilities as well as the limits of action. Finally, the relationship of actors to their environment identifies the field in which action takes place. Taken together, these three axes produce collective action. This, however, does not imply homogeneity (Vahabzadeh, 2001; Melucci, 1995 and 1984).

Movements are not unified and homogenous. Identity itself is a social phenomenon, derived from existing identity resources such as available cultural elements, which are obtained from the knowledge and information available in the society (Vahabzadeh, 2001; Melucci, 1988). Identity finds in society the conditions or resources for its existence. In movements, identity becomes emblematic of group and individual particularity. Social movements are, therefore, action systems because they have structures built by present goals (Vahabzadeh, 2001; Melucci, 1985) and can be distinguished from other forms of collective action by conflict, solidarity, and breaking the system’s limits of compatibility (Vahabzadeh, 2001; Melucci, 1989; Diani and Melucci, 1988). New social movements, thus, refer to the ongoing attempts at 
political reinstitution of societies across the world, with action being a moment of creativity, in which decisions are made out of the possibilities that manifested themselves in the context of that action (Vahabzadeh, 2001).

In contrast to the American paradigm, the new social movement theory has attempted to explain and, thereby, influence the development of movements outside developed countries. The American paradigm had little influence outside developed countries because, according to Edelman (2001), political opportunity and processes were not seen as a significant explanatory category in developing countries where anti-American sentiment dominated. ${ }^{3}$ Consequently, new social movement theory was used more often and better received in the countries it sought to examine (Edelman, 2001). The studies applied outside of Europe introduced concepts of economic and power inequalities as key dimensions of collective action. The problem was that these studies were limited to Latin America. For example, Collier (1994) introduced community factionalism and population growth as factors influencing dissatisfaction of segments within a population; Castells (1997) introduced informational movements, Nash (1997) introduced postmodern movements, and Touraine (2000) introduced democratic guerrillas. Studies on Latin America led researchers to reconsider approaches to collective action and new social movement theory (Edelman, 2001). It led to a reclassification of movements from new social movements to an approach that was concerned primarily with concepts of class and distributive politics as they pertain to popular movements (Edelman, 2001; Foweraker, 1995). The problem with new social movement theory and, later, popular movement theory was their lack of integration of structural factors to understand the links between symbols, ideas and meaning on the one hand

\footnotetext{
${ }^{3}$ Anti-Americanism in the developing world was primarily a product of the negative effect of the American government's policies. A distinction was made between the American people and its government. This does not imply American scholars did not attempt to apply their theoretical propositions to explain phenomenon in developing countries. Rather, the claim made is that much of the scholarship was not respected or taken into consideration by the countries academics sought to explain.
} 
and protest on the other (Edelman, 2001; Taylor and Whittier, 1995). Consequently, recent scholarship has attempted to integrate both the American and European paradigms, especially given the dominance of the latter being applied to developing countries.

\section{The Integrative Approach}

Renderings of an integrated approach began in the early 1990s, becoming more pronounced in the mid-1990s and clearer in the latter part of the 1990s. Gamson (1992), who called for reconciliation, claimed that the construction of an alternative culture is not the only aim of collective action but also is an effective mechanism for mobilization, as movements may construct a collective identity to maximize strategic effectiveness (Sasson-Levy and Rapoport, 2003). Ruggiero (1999), another scholar calling for the integration of the American and European paradigms, posited that both paradigms share the premise that participants in collective action are embedded in social networks, which make the adoption of a shared identity and political mobilization possible. Moreover, the paradigms shared common characteristics such as informal interaction networks, shared beliefs and solidarity, collective action focusing on conflicts, and the use of protest (Ruggiero, 1999; Della Porta and Diani, 1998). Therefore, within an integrated approach, the main processes of movements involve mounting collective challenge; reliance on social networks, common purposes, and cultural frameworks; and, the building of solidarity through connective structures and collective identities (Ruggiero, 1999; Tarrow, 1998).

Despite the calls, a systematic integrative framework amalgamating the two theoretical paradigms does not exist. The closest attempts thereto would be the works of Vasi (2006) and Simsek (2004). Jon Bogdon Vasi (2006) posited that existing American and European 
paradigms are not sufficient alone to explain contemporary movement mobilizations. ${ }^{4}$ This study also demonstrates that the paradigms are not sufficient alone to explain Islamic resistance movement mobilizations. Contemporary mass mobilizations, according to Vasi, are better characterized by the concepts of miscible movements and miscible mobilizations. Miscible movements, according to Vasi, are social movements with compatible ideologies or belief systems that can dissolve into one another, whereas miscible mobilizations are activities of communities and social movement organizations that overlap to a considerable degree. These types of mobilizations result from the simultaneous mobilization efforts of miscible movements, not from a single movement's mobilization efforts. Moreover, external processes or variations in movements' environments can increase or decrease the degree of miscibility influence mobilization. The degree of miscibility is a function of the compatibility of belief systems and a function of the degree of overlap between communities. The latter can fluctuate over time, while ideologies remain constant because of a trigger event and availability of modern communicative technologies. Movements are more likely to engage in simultaneous mobilization efforts when movement sympathizers and activists have easy access to alternative sources of information and are easily connected to one another.

Despite utility, the problem with Vasi's attempt at theory integration is that it does not tell us much about the why and how of contemporary movements. Although commended for his attempt at theory construction, the premises posited are weak. Ideological overlap may exist, but movements—old, new and contemporary—are not homogenous entities. Dissolution of movements into one another is also unlikely. Movements may cooperate and coordinate their activities, but they also simultaneously attempt to maintain an identity separate from that of other

\footnotetext{
${ }^{4}$ Here, contemporary movements are used to emphasize the difference between movements today in contrast to 'new movements' postulated by Melucci and others.
} 
like-minded movement organizations. An example of an attempt to maintain a distinct identity can be seen in the mobilization of the various braches of the Muslim Brotherhood society outside of Egypt in the 1930s (the Muslim Brotherhood of Egypt's creation of the Muslim Brotherhood Society of the West Bank and Gaza in 1935). Another example could be seen in the organizational structure of contemporary Islamic resistance movements, wherein each organizational apparatus of a particular movement is independent.

Vasi's premise that contemporary movements are characterized by miscible mobilizations is also weak. Strategies for mobilizations may overlap, but they vary given temporal and spatial differentiations. Vasi does not make clear whether he is referring to movements in America and Europe or whether he is specifically referring to movements dealing with gender, sexual orientation, or environmental issues. Regardless of the movements referred to and the environments in which they are located, contemporary movements will work in tandem with one another because they share common ideologies, goals, and objectives. However, symbolic differentiation of ideology and the methods employed exist to maintain a distinct identity from that of other movements. Again, this can be seen through the study of contemporary Islamic resistance movements-those engaged in violent and non-violent resistance—and within those movements, specifically within their organizational structures.

Simsek (2004), another theorist attempting to create an integrative framework, consolidated the different movement characteristics of the American and European paradigms and applied them to both secular and Islamic social movements in Turkey. Based on his consolidated framework and findings, Simsek compiled a list of common characteristics shared by contemporary movements. First, movements exhibit post-Marxist, post-modernist, and posttraditional tendencies. By this, they appear as critiques to socialist ideology, modernization 
processes, nation building, secularization, urbanization, the welfare state, and traditional understandings of religion and morality. Second, movements are overwhelmingly comprised of the middle-class. Third, movements have post-material, identity-oriented initiatives that demand public and political space for their characteristics, interests, and problems. Fourth, movements are both proactive and particularistic. That is, they are not merely reactions to some kind of oppression or deprivation. Instead, they are voluntary and enthusiastic initiatives that raise public consciousness about a particular issue. Finally, movements display relatively decentralized and less-hierarchical modes of organization, as well as forms of action (Simsek, 2004).

Nonetheless, the problem with Simsek's integrative framework is that it does not provide consolidated assumptions. In all fairness, this is largely due to the difficulty in consolidating the assumptions for both paradigms. Consequently, Simsek summarizes each paradigm's assumptions separately. Assumptions of the American paradigm, according to him, are as follows: that social movements are to be understood through a conflict perspective, with there being no difference between institutional and non-institutional collective action; that collective action enables groups to defend their interests in a rational way; that formation of movements depend on the availability of resources and opportunities; and, that success is measured by whether or not it is recognized as a political actor and if an increase can be observed in material benefits. Assumptions of the European paradigm, according to Simsek, are as follows: that they are comprised of middle-class participants; that movements are characterized by status other than class such as religion, gender, and sexual preference; that they are responses to the politicization of everyday life, modernity and post-modernity and, thus, address a wide social context, seeking post-material values; that their role of symbolic and cultural resistance is essential; and, finally, 
that they are organized in decentralized, egalitarian and participatory organizational forms (Simsek, 2004:115-118).

Another problem with Simsek's integrated framework is that it fails to incorporate the transnational aspects of contemporary movements. A transnational approach examines the mobilization of transnational movements, which are catalysts for globalization from below. In 1993, Falk introduced the phrase globalization from below, referring to civil society, which links transnational societal concerns with a vision for a human community, organizing across borders and raising connections (Edelman, 2001). Research in this area from the mid to late 1990s, however, focused on transnational organizations, specifically those that had crossed one or two adjacent borders, composing issue-oriented bi-national coalitions (Fox, 2000; Cunningham, 1999; Ayres, 1998). Scholars have also looked at globalization from below in terms of antecedents, protest repertories, geographic reach, and the theoretical and strategic underpinnings of globalization. For example, Rissen-Kappen (1995) examined how international governance structures legitimize transnational activists’ efforts, increase their access to national politics, and bolster capacity to form effective coalitions. Other studies examining the transnational effect on movements include these of Smith et al., (1997), Waterman (1998), Keck and Sikkink (1998).

The argument posited by theorists calling for a transnational framework views movements as a part of the growing interconnected global society that have more often than not become transnational in nature (Edelman, 2001; Mooney and Majka, 1995; Ritchie, 1996). Movements have become transnational in nature in areas where regional economic integration and supranational governance were making their weight felt at the local level. The problem, however, according to Waterman (1998) and Appaduri (2000), is that there was little or no strategic examination or articulation of a global movement theory. Contemporary movements 
are a global phenomenon, but the context of their emergence is, more often than not, neither global nor are their organization forms, struggles or objectives (Vahabzadeh, 2001). These movements, according to Appaduri, are part networks, part movements, and part organizations, which require a new theory of explanation. This study, however, does not attempt to fill the theoretical void by developing an integrated theoretical framework. Instead, it seeks to examine contemporary Islamic resistance movements through the American and European paradigms for determining whether they are generalizable, irrespective of time, space, and type of movement.

\section{Summary of the Theoretical Paradigms}

As stated, the theoretical framework employed was derived from the American and European paradigms. In the American paradigm, theorists posited that contemporary movements are a product of the political context. That is, political climate independent of movement mobilization affects the outcome of movements (Edelman, 2001; Goodwin and Jasper, 1999; Tarrow, 1998; Rochon, 1990). Movements, therefore, are symptoms of socio-economic crises (Edelman, 2001), deprivation and structural differentiation (Champagne 1983), which provide

political opportunities (Goodwin and Jasper, 1999). Mobilization is made possible by movements, who are socially connected, using political opportunities to expand and gain a stake in the political and social system (Edelman, 2001; Cohen, 1985). They do so by relying on the linkages between individuals, organizations and institutions, which blurs the line between them and established political channels such as political parties (Rochon, 1990). The blurring of the line results in changes in the level of elite receptivity, changes in elite ability and willingness to repress movements, and the presence of elite allies (Edelman, 2001; Tarrow, 1998; Rochon, 1990). It also influences the type of protest, as both strategies and tactics are not chosen in a vacuum (Meyer 1999). Choice of action, then, depends on whether there is greater or less 
openness/access (structural differentiation) and political opportunities (repression, participation, and resources) available (Meyer, 1999; Tarrow, 1992; Tilly, 1978; Eisenger, 1973). The explanatory variables the American paradigm is concerned with include socio-economic crises, deprivation, structural differentiation, political opportunities, elite receptivity, and choice of action.

The American failed to consider the role identities play in mobilization. Theorists within the European paradigm posited that contemporary movements were mirrors of conflicts found in society (Rochon, 1990). This is because conflict creates new-shared identities based on existing social cleavages (Touraine, 1988). Identities produce collective action or mobilization (Vahabzadeh, 2001) to effect relations of social domination (Edelman, 2001). The process of mobilization, according to the European paradigm, is determined by the relation of actors to the ends of their action, which provides the possibilities and limits of their action; and, by the relationship of actors to their environment, which identifies the field in which action takes place. The variables that this paradigm is concerned with include conflict, social cleavages, identity, and social domination.

For each paradigm, mobilization was explained differently. The American paradigm is strategy oriented and posited that mobilization was the product of movement activists (entrepreneurs) strategically using political opportunities, provided by political context and grievances. The European paradigm is not strategy oriented and posited that mobilization was a product of the social environment creating shared identities among movement activists. The following table summarizes and contrasts the paradigms. 
Table 1.1 The American and European Movement Mobilization Framework

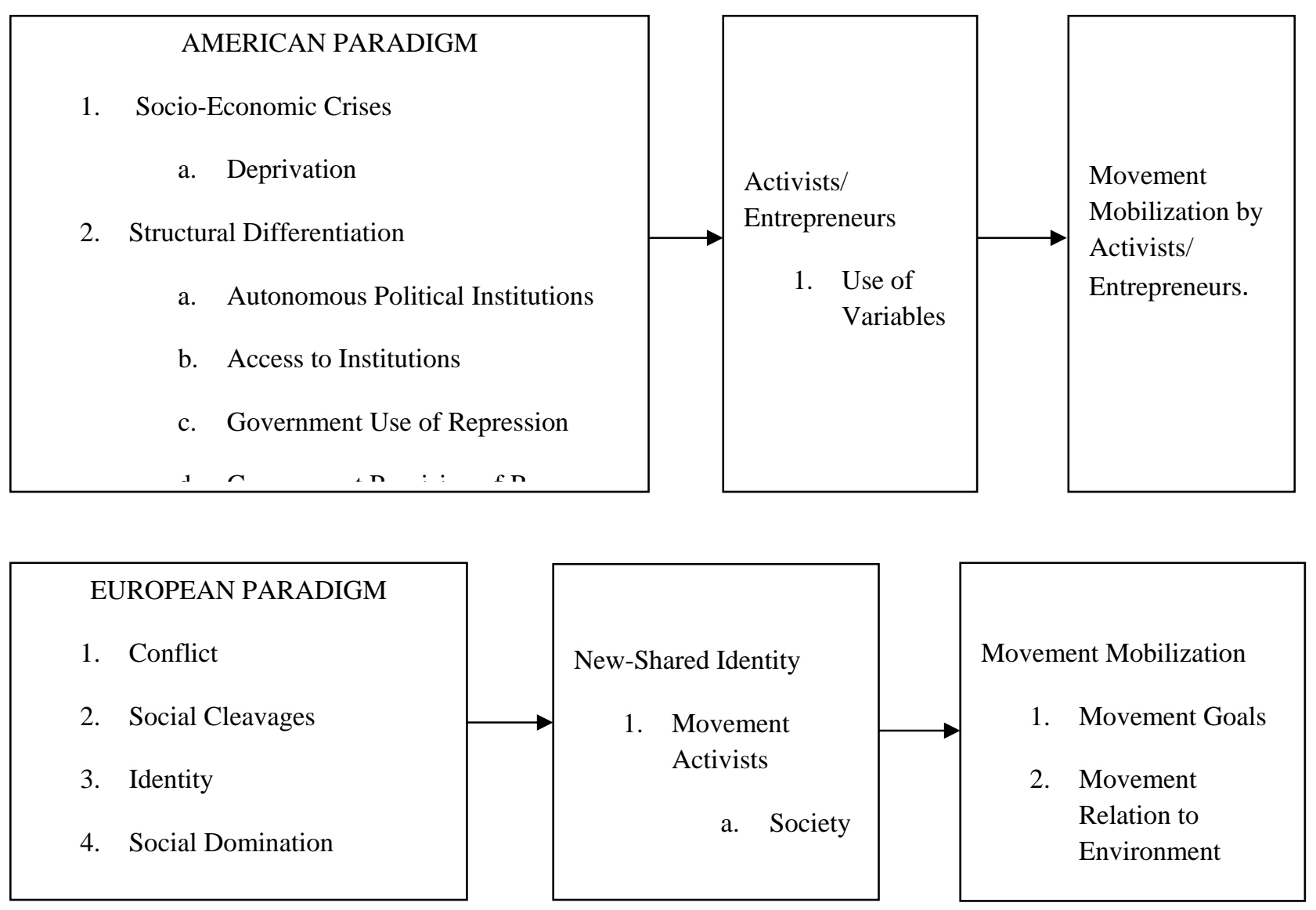

\section{Conclusion}

This chapter sought to introduce the objectives of this study and to review the existing literature on social movements. As stated, the study seeks to examine contemporary Islamic resistance movements in Algeria, Palestine, and the Philippines. The emphasis on Islamic resistance movements is due in part to the lack of scholarship within the social movement literature on these types of movements and, in part, due to the lack of scholarship within the literature on Islamic resistance movements on social movement theory. This study, therefore, seeks to bridge the gap. The emphasis on movements in Algeria, Palestine and the Philippines is 
due to the lack of social movement scholarship on these geographical regions. Social movement scholarship has been limited primarily to America, Europe, Latin America, and South Africa. The movements studied herein are located in North Africa, the Middle East, and Southeast Asia. Theoretically, this study joins social movement scholars calling for an integrated approach. Finally, by focusing on contemporary Islamic resistance movements, it seeks to identify common mobilization characteristics and to develop generalizable propositions regarding these movements.

\section{Organization of the Rest of the Study}

Chapter two sets forth the research methodology employed. The study utilizes structured, focused comparative case studies. It employs a common set of questions across cases to ensure acquisition of comparable data collection for the development of generalizable propositions. Chapters three through five examine the mobilization of each movement, within each country. In each of the chapters, movement mobilizations are examined in terms of the American and European paradigms. Chapter six draws conclusions based on chapters three through five. Specifically, it identifies the common characteristics found through the case studies. 


\section{Chapter 2}

\section{Research Design and Method: Comparing Mobilizations of Contemporary Islamic Resistance Movements}

The major questions posed in the previous chapter were whether Islamic resistance movements share common mobilization characteristics; and, if so, whether generalizable propositions could be posited regarding their mobilization. Providing answers to these questions is the primary concern of this dissertation. According to the literature presented in the first chapter, mobilization refers to the formation or creation of the movement. Mobilization of movements is not the same as the evolution of movements, which is not the purview of this study.

This study employs a comparative case approach, which permits a cross-case examination of the mobilization of the six movements through the American and European paradigms within the social movement literature. Examining mobilization from the vantage of each of the paradigms will pave the way for the future development of an integrated approach, which the literature posits is necessary. The second section focuses on the research design specifically. In particular, it will review the six Islamic resistance movements and the reason for their selection; and, how the variables from the American and European paradigms will be assessed and compared.

\section{The Comparative Case Study Approach}

Previous studies within the social movement literature examine mobilization on a caseby-case and country specific basis (Edelman, 2001; Goodwin and Jasper, 1999). These studies are multifaceted, detailed, conceptually rich, and multidimensional. Nevertheless, the lack of 
comparison across cases prohibits the articulation of generalizable propositions. That is, general hypotheses inferred from a single case study may have no theoretical value outside of the case itself (Lijphart, 1997). Because of this, social movement researchers need to conduct and compare multiple cases so they can strengthen their results via pattern matching. In particular, analysts need to employ the comparative method, which is highly conducive to hypothesis generation. The comparative method, according to Lijphart (1971), permits the establishment of general empirical propositions by discovering relationships among the variables. It is also considered the first step for generating theory (Yin, 1994; Lijphart, 1971).

Two types of cases, according to Lijphart (1971), are conducive to developing general propositions. These are theory confirming or infirming cases and deviant cases. Theory confirming cases are those wherein knowledge of the case is limited to a single variable or to none of the variables that theoretical propositions posit. In this study, only the outcome variable of mobilization is known. A common outcome variable is sufficient for case selection when the explanatory variables are of theoretical concern (King, Keohane and Verba, 1994; Yin, 1994; Lijphart, 1971). All six Islamic resistance movements selected mobilized at different times, this study is interested in determining if they did so in a similar fashion. The theoretical propositions posited by the American and European paradigms are used to direct the investigation of each movement's mobilization.

In contrast to theory confirming cases, deviant cases are those that attempt to identify differences to explain a particular phenomenon (Lijphart, 1971). The purpose of deviant cases is to cast light on the exceptional and the atypical. In particular, cases selected must differ according to some variable, which is known, for developing general propositions regarding their difference. While all of the cases in this study are similar based on the outcome variable, 
differences among them exist regarding the form protest. Two of the movements adopted violent protest as part of their mobilization strategy whereas the others used non-violent protest. The difference regarding the form of protest will permit the identification of those variables from the American and European paradigm that help to explain the variation. In particular, it will permit the development of hypotheses as to why some movements resorted to violent protest instead of non-violent protest and vice versa.

Finally, each of the cases - the six contemporary Islamic movements—are examined to determine how the variables which are the focus of the paradigms shape mobilization. While several of the movements are located within the same country, they constitute separate cases, according to Lijphart, because mobilization occurred at different times. Again, referring back to Lijphart, cases can be expanded both temporally and spatially for determining whether the explanatory variables are generalizable across cases. The explanatory variables posited by the American and European paradigms should be present across the cases, despite movement mobilization at different times or places. Presence across cases will therefore allow for confirmation of the theoretical propositions on mobilization posited by the paradigms. Comparing across cases for confirming or rejecting theory is more conducive to the development of general propositions (Lijphart 1970).

\section{The Research Design}

This section outlines the organization of each case study; discusses the criteria for case selection; identifies the variables posited by the American and European paradigms and the structured questions used for data collection; and, concludes with a discussion of the means employed to compare across cases. 
Each chapter opens with an overview of the historical context in which each movement emerged. Movements are rooted in their past, regardless of whether they are contemporary phenomenon or not (Touraine, 1988). Moreover, the socio-cultural and political contexts of the time when they mobilized are a product of history.

Each case is then discussed with respect to the variables posited by the American and European paradigms in a focused, structured case design. Each of these cases are examined immediately prior to and at the time of mobilization. Mobilization refers to the creation or emergence of movements in particular times and places. According to the social movement literature, when studies are concerned with how and why movements mobilized, it is the time of their initial mobilization that must be examined (Vasi, 2006; Semsek, 2004; Vahabzadeh, 2001; Goodwin and Jasper, 1999; Yiftachel, 1997; Herman, 1995; Melucci, 1980; Gurr, 1970). The FIS initially mobilized in 1989; PIJ in 1980; Hamas in 1987; the MNLF in 1969; the MILF in 1977; and, the ASG in 1991. At the time of their mobilization, the FIS, the PIJ, Hamas and the MNLF engaged in non-violent resistance, whereas the MILF and the ASG engaged in violent resistance. The PIJ and Hamas did not engage in violent resistance until after their initial mobilizations.

The cases were selected for several reasons. First, Islamic resistance movements in general and these cases in particular, have not been examined for the most part within social movement theory. Simsek (2006), who examined Islamic political organizations in comparison to other non-Muslim organizations in Turkey, is the exception. Like Simsek this study is an effort to postulate an integrative framework within social movement theory that applies to Islamic resistance movements. Second, existing studies on Islamic resistance movements have not examined mobilization on a cross-case basis. Studies have been limited to in-depth historical 
case analysis on single groups or on single countries. The mobilization of Islamic resistance movements have not been examined for identifying generalizable propositions common across countries and regions. Third, the cases were selected due to their geographical location. Social movement theory, as mentioned in chapter one, has largely been confined to the study of movements in America, Europe, Latin America, and South Africa. The cases herein span the Middle East, North Africa and Southeast Asia. Fourth, these specific cases were selected to further research previously conducted on their transition (the FIS, Hamas and the MNLF) and potential transition (the PIJ, the MILF, and the ASG) from resistance movement to political parties (Rudolph and Van Engeland, 2008). Finally, the cases were selected to facilitate theory testing. The American and European paradigms should explain mobilization irrespective of time, space, and the type of movements. Given that social movement theory has not examined Islamic resistance movement, with the exception of Semsek (2006), the cases become even more relevant in testing whether the propositions of the American and European paradigm are in fact generalizable.

\section{Movement Mobilization from the American Paradigm}

For the American paradigm, movement mobilization is a product of activists utilizing political opportunities provided by the environment. Chapter one summarized the theoretical propositions utilized in this study for examining the mobilization of Islamic resistance movements. Given the main premise of the American paradigm, it is posited that activists utilized political opportunities provided by the environment where they live to mobilize to create the movement. To explain mobilization for each movement, structured questions were used to guide data collection. The following chart summarized the variables, the coding categories, the indicators/questions, and the sources, which is followed by a discussion. 


\begin{tabular}{|c|c|c|c|}
\hline Variables & $\begin{array}{l}\text { Coding } \\
\text { Categories }\end{array}$ & Indicators/Questions & Source \\
\hline $\begin{array}{l}\text { Socio- } \\
\text { Economic } \\
\text { Crises }\end{array}$ & Yes/No & $\begin{array}{l}\text { Were socio-economic crises present? If so, did they lead } \\
\text { to deprivation? }\end{array}$ & $\begin{array}{l}\text { UNDP-HDI, UNCTAD, and } \\
\text { Quantitative Expert Studies. }\end{array}$ \\
\hline Deprivation & Yes/No & $\begin{array}{l}\text { Was deprivation present? If so, was it caused by the } \\
\text { presence of crises? }\end{array}$ & $\begin{array}{l}\text { UNDP-HPI and Expert } \\
\text { Studies. }\end{array}$ \\
\hline $\begin{array}{l}\text { Structural } \\
\text { Differentiation }\end{array}$ & Yes/No & $\begin{array}{l}\text { Was governance structurally differentiation? Was } \\
\text { political participation prohibited? Was there access to } \\
\text { redress grievances? }\end{array}$ & Expert Studies. \\
\hline \multicolumn{4}{|c|}{ Political Opportunities } \\
\hline \multicolumn{2}{|c|}{ Crises/Deprivation } & Did movements utilize these for mobilization? & $\begin{array}{l}\text { Movement Documents and } \\
\text { Expert Studies directly } \\
\text { quoting movement members. }\end{array}$ \\
\hline \multicolumn{2}{|c|}{ Structural Differentiation } & $\begin{array}{l}\text { Did movement use the level of structural differentiation } \\
\text { for mobilization? }\end{array}$ & $\begin{array}{l}\text { Movement Documents and } \\
\text { Expert Studies directly } \\
\text { quoting movement members. }\end{array}$ \\
\hline \multicolumn{2}{|c|}{ Level of Repression } & $\begin{array}{l}\text { Did government use repression? If so, did movements } \\
\text { use it for mobilization? }\end{array}$ & $\begin{array}{l}\text { Political Terror Score/ Expert } \\
\text { Studies/ Movement } \\
\text { Documents. }\end{array}$ \\
\hline \multicolumn{2}{|c|}{$\begin{array}{l}\text { Government Provision of } \\
\text { Resource }\end{array}$} & $\begin{array}{l}\text { Did the governing authority provide resources to society } \\
\text { for subsistence? Did movements use this for } \\
\text { mobilization? }\end{array}$ & $\begin{array}{l}\text { Expert studies/ Movement } \\
\text { Documents. }\end{array}$ \\
\hline \multicolumn{2}{|c|}{ Access to Resources } & $\begin{array}{l}\text { Did society have access to resources? Did movements } \\
\text { utilize this for mobilization? }\end{array}$ & $\begin{array}{l}\text { Expert Studies/Movement } \\
\text { Documents. }\end{array}$ \\
\hline \multicolumn{2}{|c|}{$\begin{array}{l}\text { Autonomous Political } \\
\text { Institutions }\end{array}$} & $\begin{array}{l}\text { Were political institutions free from government } \\
\text { manipulation? Use by movement? }\end{array}$ & $\begin{array}{l}\text { Expert Studies/Movement } \\
\text { Documents. }\end{array}$ \\
\hline \multicolumn{2}{|c|}{$\begin{array}{l}\text { Movement Access to Political } \\
\text { Institutions }\end{array}$} & $\begin{array}{l}\text { Did society have access to political institutions? Use by } \\
\text { movements? }\end{array}$ & $\begin{array}{l}\text { Expert studies/ Movement } \\
\text { Documents. }\end{array}$ \\
\hline $\begin{array}{l}\text { Elite } \\
\text { Receptivity }\end{array}$ & Yes/No & $\begin{array}{l}\text { Were there changes in elite receptivity to the use of } \\
\text { repression? Did elites attempt to redress societal } \\
\text { grievances? Use by movements? }\end{array}$ & $\begin{array}{l}\text { Expert studies/ Movement } \\
\text { Documents. }\end{array}$ \\
\hline
\end{tabular}

Socio-economic crises are defined as unstable socio-economic conditions, where resources are inadequate to cope with the environment (Mishara, 1996; Webb, 1994; Starbuck and Hedberg, 1977). Presence and absence of crises were determined based on the following two criteria. First, if the UNDP-HDI characterized the country's economic development as medium or low, crises were considered present. ${ }^{5}$ The HDI measures access to opportunities such as education, healthcare, income, employment, GDP and other socio-economic indicators to rank countries for determining whether they are of high, medium or low development. The HDI

\footnotetext{
${ }^{5}$ See the United Nations Development Program at www.undp.org for more information on the HDI.
} 
considers medium and low development countries as experiencing crises. Data was only available for Algeria and the Philippines beginning in 1975. The UNDP characterized both Algeria and the Philippines as having medium development. The HDI could not be used for Palestine because the index does not begin collecting separate data for the territories until 1994.

For Palestine, the UNCTAD Programme of Assistance to the Palestinian People was used as a primary source for socio-economic crises. ${ }^{6}$ The presence of crisis was determined based on their findings. The HDI and the UNCTAD sources were limited because they did not indicate the nature of socio-economic crises present. Due to this limitation, expert studies were also utilized to determine the presence or absence of crises and their nature. Expert studies indicating the presence or absence of crises provided the second criterion. Only studies where experts relied on quantitative measures for determining presence or absence and had a welldefined methodology were utilized. If crises were present, then the answer to the question indicated in Table 1 was yes.

Deprivation was defined as widespread socio-economic and cultural dissatisfaction with the existing status quo, which is perceived as inadequate to provide ordinary satisfaction (Champagne 1983; Barbar 1941). Its presence or absence was determined by the following two criteria. First, if the UNDP-HPI characterized the level of human deprivation in the country as medium or low standard of living, then it was considered present. ${ }^{7}$ The HPI measures the most basic dimension of deprivation, namely short life, lack of basic education, and lack of access to public and private resources. It specifically measures deprivation, whereas the HDI measures development. Similar to the HDI, data were only available for Algeria and the Philippines.

\footnotetext{
${ }^{6}$ See the UNCTAD Programme of Assistance to the Palestinian People at http://r0.unctad.org/palestine/statistics.htm for more information.

${ }^{7}$ See the United Nations Development Program at www.undp.org for more information on the HPI.
} 
Expert studies for Palestine were specifically relied on for determining the presence or absence and nature of deprivation. Expert studies were also used for Algeria and the Philippines. Thus, expert studies indicating the presence or absence of crises provided the second criterion. Only studies using quantitative measures for determining presence or absence were utilized. If deprivation was present, then the answer to the first question on the variable in Table 1 was yes. The same expert studies were also used to determine the nature of deprivation and its causes. If the studies determined that socio-economic crises led to deprivation, then the answers to the second set of questions pertaining to the variables were yes.

Structural differentiation was defined as a process where a structure or institution differentiates into more than one structure or institution that are structurally distinct, but taken together function as a whole (Rueschemeyer 1977; Smelser 1959). The type of governance structure; whether political institutions were free from government manipulation; and, whether political participation was permitted or prohibited indicated structural differentiation. The indicators related to structural differentiation included access to and autonomous political institutions, access to and government provisions of resources, elite receptivity and repression. Greater structural differentiation was considered present if participation was not prohibited and institutions were free from government manipulation. If there was greater structural differentiation, the answer to the first question pertaining to this variable listed in Table 1 was yes. If the answer was no, then the level of differentiation was sought. Lack of structural differentiation was considered present, 1) if participation was prohibited; or, 2) if it was limited in the sense that participation was subject to government manipulation. Transitional structural differentiation was considered present if there were changes in the governance structure either permitting or prohibiting participation. Data for structural differentiation were derived from 
expert studies detailing the history of the governance structure. Similar to the other variables where expert studies were relied on, a detailed methodology had to be used by the expert to determine yes or no and the type of differentiation.

Repressive practices include, but are not limited to, discriminatory policies ${ }^{8}$ and human rights abuses such as violence and imprisonment. The Political Terrorism Scale (1976-2006) measured the governing authority’s use of repression against its population. ${ }^{9}$ It ranks countries on five levels. The first level characterizes countries that have a secure rule of law; where people are not imprisoned for their view; and, where the use of torture or political murder is rare or exceptional. The second level characterizes countries that have a limited amount of imprisonment for nonviolent political activity, but where the few persons affected experience torture, beatings, and political murder. The third level three characterizes countries that have extensive political imprisonment or a recent history of such imprisonment; where execution or other political murders and brutality are common; and, where unlimited detention, with or without a trial, for political views is accepted. The fourth level characterizes countries where civil and political rights violations have expanded to large numbers of the population; and, where the use of murder, disappearance and torture are a common part of life. The last, level five, is the most extreme and characterizes countries that use terrorism against the entire population; and, where leaders place no limits on the means or thoroughness with which they pursue personal or ideological goals.

In this study, a country's ranking of one through four indicated the presence or absence of repression, with a ranking of level one indicating absence. A ranking of four or five was

\footnotetext{
${ }^{8}$ Discriminatory policies included prohibition on the right to express dissent (Alexander 2002) and the formation of political collectivities.

${ }^{9}$ Please see the Political Terrorism Scale at http://www.politicalterrorscale.org/ for more information.
} 
considered to indicate widespread use of repression. Any ranking lower than four, but other than one, was considered to indicate the lack of widespread use of repression. Expert studies were relied on to determine the presence and level of repression prior to 1976 in the case of the Philippines. They were also used to supplement the PTS rankings in Algeria, Palestine and the Philippines. Similar to the previous criteria, only studies that had a defined methodology for determining the presence or absence of repression were used. The determination of the presence or absence of repression was needed before the question as to whether movements utilized this as an opportunity for mobilization could be answered.

The level of structural differentiation and the use of repression provide political opportunities for activists to use for mobilization. The level of structural differentiation provides an opportunity because it determines whether activists have access to the governance structure to redress societal grievances, which are a product of socio-economic crises and deprivation. The use of repression provides an opportunity because it informs the nature of the actions available to activists. The use of socio-economic crises, deprivation, structural differentiation, repression and elite receptivity were determined by activists' reference to them in their documents, speeches or interviews. Expert studies that directly quoted movement activists, documents or speeches were also utilized. If movement sources did not directly reference the variables and their indicators, then they were not considered as having been used by movement activists. The movement documents will be discussed in the section on data collection, following the next section on mobilization from the European paradigm.

\section{Movement Mobilization from the European Paradigm}

For the European paradigm, movement mobilization is a product of the creation of a shared identity. It differs from the American paradigm because it asks the question of why rather 
than how movements mobilize. Chapter one summarized the theoretical propositions utilized in this study for examining the mobilization of Islamic resistance movements. Given the main premise of the paradigm, it is posited that a shared identity resulted in mobilization. To explain why movements mobilized, structured questions were used to guide data collection. The following chart summarized the variables, the coding categories, the indicators/questions, and the sources, which is followed by a discussion.

\begin{tabular}{|l|l|l|l|}
\hline \multicolumn{4}{|c|}{ Table 2.2 Explaining Mobilization from the European Paradigm } \\
\hline Variables & $\begin{array}{l}\text { Coding } \\
\text { Categories }\end{array}$ & \multicolumn{1}{|c|}{ Indicators/Questions } & \multicolumn{1}{c|}{ Source } \\
\hline Conflict & Yes/No & $\begin{array}{l}\text { Was conflict present at the time of movement } \\
\text { mobilization? }\end{array}$ & $\begin{array}{l}\text { Uppsala Conflict Database } \\
\text { and Expert Studies. }\end{array}$ \\
\hline $\begin{array}{l}\text { Social } \\
\text { Cleavages }\end{array}$ & Yes/No & $\begin{array}{l}\text { Were cleavages present? What type of cleavage? What } \\
\text { led to the salience of those cleavages? Which cleavage } \\
\text { were movements able to overcome? }\end{array}$ & $\begin{array}{l}\text { Expert Studies and } \\
\text { Movement Documents. }\end{array}$ \\
\hline Identity & Yes/No & $\begin{array}{l}\text { Did each of the movements have a shared identity? Was } \\
\text { their shared identity based on existing social cleavages? }\end{array}$ & $\begin{array}{l}\text { Movement Documents and } \\
\text { Expert Studies quoting } \\
\text { movement members. }\end{array}$ \\
\hline $\begin{array}{l}\text { Social } \\
\text { Domination }\end{array}$ & Yes/No & $\begin{array}{l}\text { Did the movements mobilize for affecting relations of } \\
\text { domination? }\end{array}$ & $\begin{array}{l}\text { Movement Documents and } \\
\text { Expert Studies quoting } \\
\text { movement members. }\end{array}$ \\
\hline
\end{tabular}

Conflict was defined using the Uppsala Conflict Data Program’s definition. Conflict “is a contested incompatibility that concerns government and/or territory where the use of armed force results in at least 25 battle deaths” (Uppsala Conflict Data Program). ${ }^{10}$ This study is concerned only with intrastate conflict, which is defined by Uppsala as occurring between the government and a non-government party. The database is limited because it does not provide details as to the nature of the conflict. Consequently, expert studies were also used as a supplement. If armed conflict was present, then the answer to the question pertaining to this variable listed in Table 2 was yes.

\footnotetext{
${ }^{10}$ Please see the Uppsala Conflict Dataset at www.pcr.uu.se/research/UCDP/data_and_publications/datasets.htm for more information.
} 
Social cleavages are defined by Yonhyok Choe (2002: 7-8) as a division of social members into different factions of individuals, groups, and organizations, which are broken into two categories. The first category is segmental cleavages such as divisions based on tribe, family, race, caste, language, region, sex, occupation, urban-rural, religion, or generation. The second category is value-related cleavages such as ideological or socio-economic cleavages such as education, income and class. The types of cleavages, their nature and causes were determined as being present or absent based on expert studies that had a well-defined methodology. The identification of the cause was necessary to answer the question as to whether conflict or something else exacerbated existing cleavages prior to and at the time of movement mobilization.

The determination of the presence or absence, the nature, and cause of the cleavages were needed to answer the questions related to whether the movement's identity was based on existing cleavages. Identity, first introduced by Tajfel (1997: 292), refers to “the individual's knowledge that he [or she] belongs to certain social groups together with some emotional and value significance to him [or her] of this group’s membership” (Hogg and Terry, 2000). Movement documents and expert studies that quoted movement activists or speeches were used to determine whether activists' identity was shaped by cleavages. Identity was considered to be shaped by existing cleavages: 1) if a movement’s leadership or membership included individuals from the cleavage categories; or, 2) if a movement's platform addressed concerns related to the cleavages. For example, calling for or implementing programs to assist women in Palestinian society was considered a direct reference to addressing an existing gender cleavage.

Finally, social domination refers to the dominance and subordination of one collectivity over another, which results in a social hierarchy denoting inequalities such as status differentials 
and unequal power distributions (Thapa, 1988). Mobilization for domination was determined by a movement' documents or expert studies that directly quoted movement material or activists. From these, the type of domination could also be identified. For example, if reference was made to military rule, control or dominance, then the type was identified as military domination. The reliance on movement sources for this study makes this study of Islamic resistance movement mobilization unique.

\section{Data Collection for Mobilization}

Mobilization of activists for protest is an interesting phenomenon. To understand it more thoroughly, ethnographic research was engaged in during the summer of 2007 in Palestine. Ethnographic fieldwork permits and understanding of the behavior and thought of the phenomenon under study (Madison, 2005; Goulon, 1995). Through ethnographic fieldwork, I participated in and observed non-violent protests; received training on how to deal with the Israeli soldiers' potential use of ammunition and tear gas and to prevent against arrest; and, interviewed organizers of the protests on mobilization and symbolism. The forms of non-violent protests engaged in differed, ranging from assisting in the construction of houses destroyed by the Israeli Defense Force, observing checkpoints and settlement construction, to participating in demonstrations. Non-violent demonstrations occurred every Friday at different times and locations throughout the West Bank. In addition to participating in non-violent forms of protest, I interviewed elected officials from Fatah, Hamas and the PIJ. In the interviews, questions pertained to social and political context, identity, symbolism, goals, and the use and effectiveness of protest (violent/non-violent). The combination of ethnographic techniques informed only my understanding of the behavior and thought of activists and the why and how of their mobilizations. 
The study of the why and how of their mobilizations was informed by the use of movement documents, speeches and interviews. In the case of the Islamic Salvation Front, documents, speeches and interviews in both Arabic and French were obtained from the movement's information bureau. In the case of the PIJ, documents, speeches and interviews in Arabic were obtained from the information bureau of the movement's political wing; and, from the information bureau of al-Saraya al-Quds Brigades, which is the movement's military wing. In the case of Hamas, documents, speeches and interviews in Arabic were obtained from the information bureau of the political wing; and, from the information bureau of al-Ezzedine alQassam Brigades, which is the movement's military wing. The cases of the MNLF, the MILF and the ASG were the only movements where documents could not be obtained. For these movements, secondary sources that directly quoted movement activists, documents or speeches were used. Secondary sources that directly quoted movement activists or material were also used for the FIS, the PIJ and Hamas. Analysis of the documents followed the criteria set forth in the sections on the American and European paradigms.

Movement sources and expert studies that directly quoted movement sources were determined to be the best method for acquiring an understanding of how and why they mobilized. According to Geertz (1973), the “other” can only be known and understood from their perspective. Reliance on secondary analysis limits the credibility of understanding the how and why of actors' actions and poses issues of bias. All researchers have their biases, but to rely on secondary analysis of movement ideas, goals and actions perpetuates those existing biases and distorts the perspective of the "other." The reliance of movement sources also presents an issue of bias, as it presents those of the subject. Nevertheless, it was felt that the best way to capture 
an understanding of the why and how movements mobilized was to understand it from the perspective of the activist.

\section{Comparing Islamic Resistance Movements’ Mobilizations}

While the mobilizations of the six contemporary Islamic resistance movements are treated separately, the evidence found therein are analyzed comparatively in the final chapter of this study. Comparative analysis is used to tabulate those explanatory variables that are common across cases to explain mobilization. It is also used to tabulate the explanatory variables that are specific to only movements engaged in violent resistance. Through comparative analysis, this study will be able to identify whether Islamic resistance movements share common mobilization characteristics and to posit generalisable propositions regarding these movement mobilizations.

\section{Conclusion}

This chapter sought to present the research methodology, which compares the mobilization of six contemporary Islamic resistance movements that differ temporally and spatially. The first section of this chapter examined why comparative analysis was used. The second section examined the research design specifically. In particular, it reviewed the six Islamic resistance movements and the reason for their selection. Then, it defined and identified the explanatory variables posited by the American and European paradigms to help explain movement mobilization. Finally, it discussed the way in which each will be compared in the concluding chapter. 


\section{Chapter 3}

\section{Mobilizing the Islamic Salvation Front in Algeria}

This chapter examines the case of the Islamic Salvation Front (FIS). ${ }^{1}$ Formed in 1989, the FIS was an effort by various Algerian Muslim groups to create a unified collectivity to challenge the FLN politically. Through consultation, Muslim political activists determined that creating separate political entities would divide rather than unite the Islamist movement (Islamic Salvation Front, 2003). Division, the FIS believed, would prevent an effective challenge to the National Liberation Front (FLN). Despite its recent mobilization, the FIS is rooted in and shaped by the historical development of Algerian nationalism, as the following section demonstrates.

\section{Brief History of Algeria from French Colonization to Independence (1830-1962)}

Colonization or foreign occupation influenced the historical development of all the countries included in this study, but only Algeria and the Philippines were able to obtain a sovereign entity to call home. The French colonized Algeria for 132 years before it achieved independence in 1962, after an eight-year rebellion (Burke III, 1998; Celik, 1996; Gillespie, 1960). Given this long history, a brief survey of French colonization is necessary to understand the development of Algerian nationalism. This section will briefly examine the conditions prior to and during the period of French colonization, the development of Algerian nationalism, and

\footnotetext{
${ }^{1}$ Not examining other movements in Algeria for identifying dissimilarities could present a weakness. The overall study is concerned with taking a sample of the mobilization of movements across geographical locations and temporal differences. Consequently, the examination of one movement in Algeria was felt to be sufficient given that the majority of the other movements mobilized simultaneously and had similar mobilization patterns. FIS is the only movement examined in Algeria for several reasons. First, the other contemporary Islamic movements in Algeria were created by the FLN simultaneously to counter-balance FIS (Entelis, 1992; Also see the discussion under the variable structural differentiation for further explanation). Second, FIS represented the Islamic bloc (Tahi, 1995). Finally, the overall study is not focused on making in-country generalizations.
} 
the Algerian Muslim Rebellion of 1954. The latter led to the FLN and its dominance in the governance system.

Prior to French colonization, the Turks dominated Algeria under the Ottoman Empire (Gillespie, 1960). Before their arrival, the region had multiple kingdoms, fiefdoms and other divisions (Reudy, 2005). The arrival of the Turks in historic Algeria established a collective political identity between the $16^{\text {th }}$ and $18^{\text {th }}$ Centuries. Turkish military rule was turbulent and marked by assassinations, revolts, and massacres due to Algeria's strategic location within the region (Reudy, 2005; Gillespie, 1960). Although it had become increasingly independent by the $17^{\text {th }}$ Century, economic crises and power inequalities of the $18^{\text {th }}$ Century provided the conditions that led Turkish authorities to surrender to the French in 1830. While the Turkish rulers surrendered quietly, the same cannot be said for the local Arab and Berber populations. Emir Abd El-Kader led an armed rebellion against the French for 17 years that ended in 1871 (Burke, 1998; Gillespie, 1960). The rebellion, according to Gillespie (1960: 20), was not due to the invasion but rather Algerian attachment to the land and Islam, both of which the French denied to Algerians.

From the 1830s to the end of 1870, France governed Algeria militarily, suppressing all forms of culture and socio-cultural institutions not deemed progressive or modern. This suppression in part fueled the El-Kader Rebellion that lasted until 1871. Afterward, Algerians protested peacefully until the 1907 Young Algerian Revolt. This revolt was significant in Algerian political history because it was the first time Algerians created a political party, even if it did not last long. There was a short break in French military governance from 1848 to 1852, when the Colons (European settlers) were able to wrestle control from the military. Their rule ended in 1852 with the passage of the French Constitution, which prohibited Algeria from 
having legislative representation. Despite this, from 1848 to 1945, the civilian administration consisted of 24 Algerian Muslims and 48 Colons. The Colons were able to regain control of the governance structure in 1870. From 1870 to independence, the Colons dominated the Algerian governance structure, with a few "Muslim Yes-men” (Gillespie, 1960: 75) incorporated into the system in 1898.

The Colon's alienation of Muslims led to the first Algerian Muslim Rebellion of 1945. The trigger event for the rebellion was widespread use of repression by the Colons to demonstrations. Demonstrations occurred following the celebrations of allied victory and changes in the scheduled Algerian elections. Elections were changed out of the Colons fear that Algerian secessionist candidates would win the elections. The 1945 revolt ultimately resulted in the passage of the 1947 Statute, which granted Algerians additional rights such as easier access to citizenship and greater electoral participation. Previously, the granting of citizenship depended on Algerians renouncing their rights granted by Islam. However, the recognition of rights and their actual implementation were two different stories. Equal representation was never realized, despite the role Algerians played in the two World Wars.

The failed enforcement of the statute was due, in part, to pro-Algerian, liberal elites in France being preoccupied with French domestic problems. It was also due to the armed insurrections against French rule in Morocco and Tunisia. Consequently, the Colons were able to reassert their political control in Algeria, which resulted in the removal of Algerian Muslims elected to the Algerian Assembly. This further polarized the Algerian Muslim masses and the Colons. Polarization provided a strong base for the quasi-political collectivities calling for secession, which facilitated Algerian nationalist sentiment. 
An Algerian nationalist sentiment, according to Burke (1998), began to take shape in the late 1930s and early 1940s through historical wars fought discursively between the French (Colons) and the Algerians. The Colons defined themselves as the bearers of progress and the Algerians defined the French and the Colons, in particular, as oppressors who deprived them of their culture and history. In so doing, Algerians emphasized the violent nature of the French conquest and the continued suppression of the Algerian people, the illegitimate appropriation of land and resources, and the inequality wrought by the colonial governance structure (Burke, 1998; Gillespie, 1960). National discourse, therefore, was built around the notion that victims can only know the "other" by the scars and chains that imprison their mind, body, and soul (Fanon, 1963: 13). These conditions gave rise to the development of quasi-political collectivities that worked within the French framework.

Prior to the 1954 rebellion, Algerians worked within the French framework and through French political parties (Gillespie, 1960). For example, in 1927, Messali Ahmed Ben Hadj, the father of Algerian nationalism, worked with the French Communist Party to create the North African Star (ENA), which called for an independent North Africa. While this party went underground after its banning, it reemerged in 1933. In 1934, the ENA became the National Union of North African Muslims, but it did not last long. Its leader, Messali Ahmed Ben Hadj, was sentenced to one year in prison for reconstituting a banned party and then afterward went into self-imposed exile in Switzerland. Nevertheless, in 1936, Ben Hadj reconstituted the ENA with the creation of the Algerian's People Party (PPA).

While the PPA mirrored the ENA, it differed from its predecessor. The new ENA-PPA was confined solely to Algeria. This party won the municipal elections and was the first to advance Algerian independence. Another significant quasi-political entity was the Federation of 
Elected Muslims. The Federation of Elected Muslims was comprised of Muslim elites who represented Algerian Muslims in local elected bodies. They joined with the ENA-PPA in 1936 to form the Algerian Muslim Congress, which only lasted until 1937. After which, there was a spilt that resulted in the creation of the Franco-Muslim Algerian Rally and the Popular Algerian Union. Aside from these, other Algerian political and quasi-political collectivities that developed under colonization included the Popular Algerian Union, the Friends of the Manifesto and Liberty (AML), the Democratic Union of the Algerian Manifesto (UDMA), Movement for the Triumph of Democratic Liberties (MTLD), ${ }^{2}$ and the Algerian Society of Reformist Ulema. ${ }^{3}$

These political and quasi-political collectivities provided the foundation for the Algerian national sentiment, which was solidified during and after the 1954 Algerian Muslim Rebellion (Gillespie, 1960). The trigger for this rebellion, which ultimately led to Algerian independence in 1962, was the success of violent resistance in Tunisia and the failure of past attempts by Algerians to work within the French framework and French political parties. ${ }^{4}$ The 1954 rebellion was unique and unlike past attempts, because it was the first time Algerians united to fight the French. This is, in part, what made the rebellion more successful than past attempts. Previous armed insurrections failed due to a lack of organization and a fragile unity among Algerian Muslims (Gillespie, 1960: 58). It was also successful because the rebellion solidified the Algerian national identity that began to emerge in the 1930s and 1940s. The identity was

\footnotetext{
${ }^{2}$ The MTLD replaced the PPA in 1946

${ }^{3}$ The Algerian Society of Reformist Ulema was established in 1931. It was very influential despite the fact that it did not concern itself with politics. All candidates, French and Algerian, sought the Ulema's support before running for election.

${ }^{4}$ Paraphrasing Fanon (1967: 55), the violence of decolonization is instructive for others who aspire to the same goal. Moreover, the goal itself, decolonization, confers sovereignty that in turn engenders respect from others. This was the mentality of the Algerian nationals that led the 1954 Rebellion, which was accepted by the overwhelming majority of Algerian Muslims, who had been colonized for more than 132 years.
} 
further forged by mass poverty and repression, which provided concrete goals and means to the activists that mobilized to lead the rebellion (Burke III, 1998; Celik, 1996; Gillespie, 1960). Those activists mobilized to create the National Liberation Front.

In conclusion, Algerian mobilization under French colonization demonstrated the importance of identity, crises, deprivation, conflict, structural differentiation and political opportunities for the attainment of Algerians political ends. During colonization, Algerians were denied their identity and culture. They experienced deprivation due to unequal socio-economic policies, which created crises among the disaffected. Algerian Muslims were unable to challenge the French governance structure inside conventional political boundaries due to a lack of structural differentiation. Political activists were prohibited from taking part in the system due to the domination of Colons, who feared Algerian Muslim secession. Activists had to mobilize outside the conventional political boundaries. This led to the creation of the FLN. The military and political success of the FLN contributed to their dominance of the post-independence governance structure. It was because of the FLN's dominance that contemporary movements such as the Islamic Salvation Front (FIS) have their roots in the Algerian nationalism forged under French colonization. FIS, therefore, is very much a part of and operated within the Algerian nationalist framework.

\section{FIS Mobilization from the American Paradigm}

The conditions in Algeria were relatively similar to those under French colonization, which aided activists in the mobilization of the FLN. The period prior to and at the time of the FIS mobilization was characterized by socio-economic crises, deprivation and transitional structural differentiation. According to the American paradigm, crises, deprivation and level of structural differentiation do not cause mobilization. Rather, they provide political opportunities 
for activists to utilize. For the American paradigm the role of the activists enables mobilizations. This section examines the enabling explanatory variables and the way activists utilize them to explain the mobilization of FIS.

Socio-Economic Crises, Deprivation and Structural Differentiation. Crises in the form of unstable socio-economic conditions were present when FIS mobilized (United Nations Human Development Index). In particular, Algeria was “...plagued by over-population, inadequate housing, over-urbanization, unreliable food production and supplies, a decrepit transportation system, chronic water shortages, over-crowded schools, poor quality medical facilities and health services, uncontrollable birth rates, and high rates of unemployment and underemployment” (Entelis, 1992: 15-16). These conditions were a product of socio-economic crises. The crises were a result of the economic policies implemented in the 1980 s. $^{5}$ Specifically, it was severe cuts to many of the socio-welfare programs, consumer cooperatives, and transportation and housing subsidies (Alexander, 2002; Layachi, 2001). These contributed to segments of the population becoming disaffected. Initially, those most isolated were small businesses, low-level bureaucrats and administrators, the educated, and the middle-class (Layachi, 2001; Chhibber, 1996). It was not until the sharp decline in oil revenues throughout the 1980s that larger segments of the population became disaffected. By 1988, crises and the government reduction in socio-welfare benefits to the lower socio-economic class resulted in widespread deprivation.

According to the American paradigm, crises lead to deprivation (Yiftachel, 1997 and 1992; Zureik, 1993; Haidar, 1991). Deprivation was present prior to and at the time of the FIS mobilization. In particular, it was present from 1975 to 1989 (UNDP Human Poverty Index). Christian Alexander (2002) found that social, political and economic deprivation in particular

\footnotetext{
${ }^{5}$ See Layachi (2001) and Chhibber (1996) for more detail on the economic conditions and policies during the period of 1970 to 1991.
} 
characterized the period between the 1970s to the 1990s. Socially, there was widespread dissatisfaction when the government cut social expenditures, which Algerians viewed as their right as citizens. Political dissatisfaction was due to the domination of one-party rule, with the people voting for the candidates selected for them by the ruling party; ${ }^{6}$ the prohibition against freedom of expression; ${ }^{7}$ and, the prohibition in the formation of political collectivities. Economically, deprivation was a product of an economic downturn in Algeria due to declining oil prices and rising debt (Layachi, 2001).

Crises and deprivation extending to widespread segments of the population resulted in the October 1988 protests. These protests brought the young and old, the educated and uneducated, and the employed and unemployed together to express their dissatisfaction with the existing status quo. Protest outside of conventional political boundaries was a product of Algerians being unable to challenge government policies due to a lack of structural differentiation (Alexander, 2002; Layachi, 2001; International Crisis Group, 2001; Tahi, 1995; Roberts, 1995; Entelis, 1992).

According to the American paradigm, structural differentiation is important because it determines whether activists have access to the government to redress the causes of deprivation. From the time of independence in 1962 and until the passage of the 1989 Constitution, the Algerian government was not structurally differentiated (Entelis, 1992 and 1980). Rather, it was politically dominated by the FLN. When the government was established in 1962, all opposition parties were either banned or placed under the firm control of the party. The first Algerian President, Ben Bella, codified prohibition against political parties.

\footnotetext{
${ }^{6}$ To be eligible as a candidate an individual had to be a member of FLN.

${ }^{7}$ The government controlled the media and often used repression for any form of public displays of discontent.
} 
Ben Bella was replaced in 1965 in a bloodless coup led by Boumedienne, who remained in office until his death in December 1978. From January 1979 and until he was forcibly removed by the military in 1989, the Algerian government was headed by Benjedid, who was appointed by the military. Similar to the political conditions under Ben Bella's tenure, political parties and public displays of discontent were prohibited from taking place outside the Party. This meant that opposition could only take place inside the FLN or through one of the six legal organizations authorized and headed by members of the FLN. ${ }^{8}$ Consequently, all institutions were subjected to manipulation by the governing authority. The government did not interfere so long as they operated within the governing structure and did not conflict with the governance of FLN. If they conflicted, then they were replaced, banned or shut down (Entelis, 1992 and 1980). The FLN is comprised of multiple factions or collectivities, with three main constituencies - the party, the government, and the military. The main constituent part of the FLN is the party, which is headed by colonels and the heads of military regions throughout Algeria. The party did not take-on a separate political identity until 1991, when it refused to support a military coup to overturn FIS' majority win in the elections. Prior to 1991, the party was dominated by military, with its officials holding the majority of the governmental positions (Tahi, 1995).

The military collectivity is comprised of the Army and the Securite Militaire (SM). The Army was the dominant constituent part of FLN since its creation in the 1950s. Its dominance in the governance structure did not occur until 1963, when Boumedienne led a bloodless coup

\footnotetext{
${ }^{8}$ These six legal institutions included a workers union (UGTA), a famers union (UNPA), a youth association (UNSA), an organization comprised of former mujahidin — freedom fighters from the War of Independence(ONM), a women's association (UNFA), and a student union (UNEA). The latter, however, was disbanded in the 1970s due to it attempting to challenge the centralized authority of the government. Political parties and the formation of quasi-political collectivities were not permitted until the passage of the 1989 Constitution, which legalized freedom of expression and the creation of political parties.
} 
against Ben Bella and installed the Council of Revolution. It was from then on that the Army directly controlled all positions of authority by selecting candidates and appointing government officials (Tahi, 1995; Entelis, 1980). The Securite Militaire (SM) was created in 1965 by Boumedienne to counter-balance the Army. The SM's main function was to sow chaos and discord within areas and collectivities that had the potential to threaten the government and FLN's political dominance. For example, it established the organizations of FFS2 and RCD in an attempt to thwart the popularity of FFS. It established the Coordination National of the Mouvment Cultural Berbere (MCB) in an attempt to thwart the Berber Cultural Movement (BCM). Finally, it established the Armed Islamic Group (GIA), Hamas and Enhada to thwart FIS. While it was supposed to be officially dissolved in 1989, it continued to operate clandestinely. (Tahi, 1995). The three FLN constituencies were united by one common ideological foundation (Tahi, 1995; Entelis, 1992 and 1980), which was Arab-Muslim nationalism $^{9}$ (International Crisis Group, 2004; Knauss, 1987). Islam was defined as the foundation of the identity of Algeria. ${ }^{10}$ The role of the state was to provide material benefits and to promote Islamic principles and morality (International Crisis Group, 2004 and 2003; Marrouchi, 2003; Layachi, 2001; Monshipouri, 1998; Zoubir, 1996; Tahi, 1995).

In conclusion, the lack of structural differentiation prior to 1989 resulted in protests occurring outside conventional political boundaries. These protests did not occur though until crises caused widespread deprivation among all segments of the population, which was not until 1988. When these protest erupted the government used repression to suppress all segments of

\footnotetext{
${ }^{9}$ Arab-Muslim nationalism in Algeria combined the ideas of pan-Arabism with pan-Islamism.

${ }^{10}$ FLN's Islamic political ideology juxtaposed the Muslim Brotherhood and Salafiyya traditions and socialism.
} 
society. Repressionary practices include, but are not limited to, discriminatory policies ${ }^{11}$ and human rights abuses such as violence and imprisonment. ${ }^{12}$ In 1988, the Political Terror Scale ${ }^{13}$ indicated the government's use of repression such as murder, disappearance, and torture as widespread. While there was not elite opposition to the use of repression, widespread dissatisfaction did result in there being a change in elite receptivity (International Crisis Group, 2004 and 2003; Alexander, 2002; Tahi, 1999; Entelis, 1992 and 1980; Knauss, 1987). The change in elite receptivity led to the passage of the 1989 Constitution. The constitution authorized the creation of political parties and freedom of expression, which marked the transition from less to greater structural differentiation. It was in this period that the activists, who led the 1988 protest, began to mobilize to create the FIS. The American paradigm posited that structural differentiation and socio-economic crises, which caused deprivation, provide activists with political opportuneities.

Political Opportunities. The activists that created the FIS utilized political opportunities provided by less structural differentiation, lack of access to governance structures, and lack of ability for political parties or quasi-political collectivities to form, participate and challenge the

\footnotetext{
${ }^{11}$ Discriminatory policies included prohibition on the right to express dissent (Alexander 2002) and the formation of political collectivities, as already discussed.

${ }^{12}$ Human rights abuses such as violence and imprisonment occurred against those who expressed political dissent within the public sphere, but they were not widespread (Entelis 1980 and 1992).

${ }^{13}$ Level one characterized countries that are secure rule of law, where people are not imprisoned for their view, and the use of torture or political murder is rare or exceptional. Level two characterized countries that have a limited amount of imprisonment for nonviolent political activity, but where few persons are affected and torture, beatings, and political murder are rare or exceptional. Level three characterized countries that have extensive political imprisonment or a recent history of such imprisonment, where execution or other political murders and brutality are common, and where unlimited detention, with or without a trial, for political views is accepted. Level four characterized countries where civil and political rights violations have expanded to large numbers of the population, wherein the use of murder, disappearance, and torture are a common part of life and affects those who interest themselves in politics or ideas. Level five, the extreme, characterized countries that use terror overall the population, wherein leaders place no limits on the means or thoroughness with which they pursue personal or ideological goals.
} 
governance structure. The creation of the FIS, according to Ahmed Semozrag, head of the Department of Human Rights of the FIS, was to restore Algerian sovereignty by ending the military dictatorship of the FLN and its corruption (Islamic Salvation Front, 2003: 73). The FIS thereby signified its rejection of the status quo that had been plagued with corruption and authoritarianism since $1962 .{ }^{14}$ Rejection of the status quo resonated particularly with those born post-independence, who were most affected by the unstable socio-economic conditions. The FIS, thus, presented itself as representing the masses. In fact, one of its leaders, Ben Hadj, led the 1988 protesters. Its separation from the status quo was reified that encompassed cultural, educational, socio-economic and political policies.

FIS cultural policies stem from the belief that the evils plaguing western societies such as AIDS, sexually transmitted diseases, degradation of morality, crime, and corruption need to be combated (Rudolph and Van Engeland, 2008; Islamic Salvation Front, 2003). Culturally, its platform sought to unite the Islamist trends of both the Muslim Brotherhood and Salafiyya traditions. ${ }^{15}$ FIS provision of socio-cultural and socio-economic benefits to society, however, resulted in its cultural policy being strategically linked to the rest of society. In particular, the FIS provided the working class neighborhoods with effective local policing, affordable markets, and a de facto welfare system. ${ }^{16}$ Development of social welfare programs, separate from

\footnotetext{
${ }^{14}$ In fact, the discourse used by FIS to refer to the FLN was "les voluers du FLN," the thieves of the FLN, and "l'etat impie,” the impious state (International Crisis Group, 2004).

${ }^{15}$ The ideological trends are discussed under the European paradigm.

${ }^{16}$ Its social infrastructure was built on the existing Islamist infrastructure developed over the years prior to Algeria's independence to the present. Even after its outlawing, FIS continued to collect taxes from urban quarters and rural areas under their control. This enabled it to continue providing socio-welfare benefits to society (Rudolph and Van Engeland, 2008; Silverstein, 2002).
} 
government institutions, established a support base within the rural and urban areas, provided a constituency for mobilization, and gave credibility to the FIS claim it could govern.

Educational policy, according to the FIS, is the foundation for development. Consequently, all people should be taught rationalism, logic, ethics, history, sciences, and the broad principles of Islam without differences (Islamic Salvation Front, 2003). Consequently, the FIS supported an increase in budgets and extension of school year (Rudolph and Van Engeland, 2008; Layachi, 2001). Its emphasis on education resonated with the Islamist bloc, represented by the Muslim Brotherhood and the Salafiyya traditions, and the urban-rural youth, who had protested throughout the 1980s for educational reform. Consequently, the FIS was able to draw from this constituency for mobilization.

Economically, the FIS program deviated from the government's planned economic and interventionist policy by providing an alternative based on capitalist principles of trade, industry and agriculture, and the development of entrepreneurial and private initiatives as sources of wealth (Rudolph and Van Engeland, 2008; Layachi, 2001). ${ }^{17}$ This resonated with the middle and business classes in both urban and rural areas. By providing an alternative that addressed both middle and lower socio-economic sectors, the FIS was able to build a coalition composed of all segments of society for its mobilization.

Politically, the FIS platform was premised on its participation and negotiation with all political entities in Algerian society (Islamic Salvation Front, 2003). Rooted in the principle that a party voted into power may be voted out and derived from the principle of consultation and

\footnotetext{
${ }^{17}$ It argued that FLN's planned economy was the source of oppression that retarded and discouraged private initiative and, instead, advocated less state intervention, protection from foreign intervention, privatization and reform of nationalized properties, and support for small and medium businesses. In the commercial sphere, it wanted the abolishment of monopolies and their replacement with competition (Rudolph and Van Engeland 2008; Chhibber 1996).
} 
acceptance of all within society, the platform was significant because it attempted to unite all behind its mobilization. The notion of participation resonated with those prohibited from publicly participating in the political system due to one-party rule since 1962. The FIS platform also indicated an end to less structural differentiation in that it advocated the acceptance of all, irrespective of language and culture. The purpose of this was three-fold. First, it specifically directed attention to the FLN's lack of acceptance of the Berber language and culture. Second, it directed attention to the FLN's unwillingness to except any ideology that conflicted with its own. Finally, it sought to alleviate fears among the secular and socialist trends that feared the implementation of a purely religious platform.

The FIS platform, therefore, sought to promote unity and solidarity among those it represented within its own network and with society-at-large. Anything contrary to unity and solidarity, the FIS argued, was opposite to its ideology (Islamic Salvation Front, 2003). By doing so, it attempted to attack the FLN ideologically, as they represented the status quo. The FIS also attempted to galvanize the political divisions within the FLN, particularly those between the party and the military. In so doing, it was able to change elite receptivity and harness support within the political elite of the FLN. Finally, the use of non-violent resistance for mobilization distinguished the FIS from the military. It did so in the sense that the military violently repressed Algerians in October 1988, which was fresh in their institutional memory.

In summary, the FIS utilized all the political opportunities provided except for the government's use of repression. In particular, it used the opportunities provided by crises, deprivation, structural differentiation, lack of access to and the absence of autonomous political institutions, and lack of access to and the inadequate government provision of resources. Consequently, the FIS case confirms the American paradigm's proposition that movements 
utilized political opportunities to mobilize. It also confirms the proposition that the political opportunities were utilized to create linkages between individuals, institutions and organizations, which blur the line between movements and conventional political parties. For the FIS, the blurring of the line produced changes in elite receptivity, which confirmed the paradigm's proposition. Finally, the American paradigm posited that political opportunities and structural differentiation define the choice of action.

Choice of Action. Whether action takes place inside or outside conventional boundaries, according to the American paradigm, depends on greater or less openness/access (structural differentiation) and political opportunities (Meyer, 1999; Tarrow, 1992; Tilly, 1978; Eisenger, 1973). In the case of the FIS, there was a transition from less to greater structural differentiation underway and political opportunities at the time of its mobilization. The mobilization of the FIS, prior to the creation of its organizational structure, occurred outside conventional boundaries. That is, the government had banned all public displays of protest, which meant that any occurrences were illegal and those who engaged therein were subjected to repressionary tactics. Despite prohibition, all segments of society turned out in droves to protest the unstable socioeconomic conditions and lack of freedom of expression and political participation. Those who created the FIS in 1989 led the protesters. This case demonstrates that transitional structural differentiation and political opportunities explain participation outside conventional political boundaries, which confirms the paradigm's proposition.

\section{Mobilization from the European Paradigm}

Under French colonization, there were conflicts that exacerbated existing social cleavages. The cleavages created a shared identity among the FLN activists that mobilized to affect relations of political domination. The mobilization of the FIS was made possible by the 
creation of a shared identity among activists. For the European paradigm, it is the creation of a shared identity that produces mobilization and not activists' use of political opportunities. Therefore, this section examines the role of identity in the FIS mobilization.

Conflict and Cleavages. The European paradigm posited that the presence of conflict exacerbated existing social cleavages. Armed conflict, in contrast to the other cases in this study, was not present when the FIS mobilized (Uppsala Conflict Dataset). ${ }^{18}$ Therefore, conflict did not exacerbate social cleavages and thus produce a shared identity among the activists that formed the FIS. Its lack of presence does weaken the argument of the generality of the paradigm's proposition. The proposition may need to posit conflict or crises. Crises, as will be demonstrated, did exacerbate existing cleavages, which thus provided a shared identity among activists.

Socio-economic crises made salient ethno-religious, gender, geographical, generational and class-based cleavages. Existing ethnic cleavages were united by a shared Muslim identity (Silverstein, 2002; Layachi, 2001; Tahi, 1995; Roberts, 1995). ${ }^{19}$ As previously mentioned, the FLN defined Islam as the foundation of the social identity of Algeria and the role of the state being the provision of material benefits and the promotion of Islamic principles and morality though the creation of religious institutions (International Crisis Group, 2004 and 2003; Marrouchi, 2003; Layachi, 2001; Monshipouri, 1998; Zoubir, 1996; Tahi, 1995). The Muslim identity was further reified by anti-colonial nationalism that emerged under French colonization (International Crisis Group, 2004 and 2003; Marrouchi, 2003; Layachi, 2001; Monshipouri, 1998; Zoubir, 1996; Tahi, 1995). A cleavage in the Muslim or ethno-religious identity,

\footnotetext{
${ }^{18}$ See chapter two for the definition of conflict used by the Uppsala Database.

${ }^{19}$ Berbers only constitute twenty percent of the Algerian population. Although the government refuses to recognize their distinct culture and language, Berbers do identify with and feel a belonging to Algerian society (Knauss, 1987).
} 
immediately prior to and at the time of the FIS mobilization, was made salient by unstable socioeconomic conditions. In particular, the government's reduction of socio-economic welfare benefits (Layachi, 2001; Chhibber, 1996).

Gender cleavages have always been salient due to the patriarchal nature of Algerian society, which was even the case under French colonization (Amrane-Minne, 1999). Under French colonization, the military and colon administrations repressed and prohibited the public participation of women. After independence, under the FLN, the status of women did not improve despite the active role they played in the 1954 Rebellion. The FLN accepted their role on the battlefield, but continued to exclude them from public participation. Gender identities, while always having been salient, were made more so by the suppression (Amrane-Minne, 1999) and unstable socio-economic conditions due to unemployment and underemployment (Layachi, 2001).

Like gender, geographical or urban-rural based cleavages were present prior to, during and after French colonization (Knauss, 1987). At the time when the FIS mobilized, these cleavages were made salient due to under-development and lack of resources (Silverstein, 2002; Layachi, 2001; Knauss, 1987). Urban areas had better access to resources that aided in their development in contrast to rural areas (Silverstein, 2002). Within both the urban and rural areas, cleavages were made salient by the unstable socio-economic conditions. Within the urban areas, cleavages existed between the economic elite and those of lower socio-economic classes. ${ }^{20}$ Within the rural areas, cleavages existed between those who owned land versus those who worked the land (Knauss, 1987). Geographical or urban-rural based cleavages were exacerbated

\footnotetext{
${ }^{20}$ For example, in May of 1983, 100,000 Algerians, many among the poorest of Algiers 2.5 million inhabitants, lived crammed together in the 1,700 buildings of Casaba. In those dwellings, which are owned by property owners within the upper socio-economic classes, families of eight to ten live in crowded single-rented rooms, in primitive, unsanitary conditions.
} 
by the unstable socio-economic conditions and generational cleavages (Silverstein, 2002; Layachi, 2001; Knauss, 1987).

Generational cleavages were present in Algerian society among Algerians raised in the pre-independence period versus those raised in the post-independence period (Silverstein, 2002; Layachi, 2001; Tahi, 1995; Roberts, 1995; Entelis, 1992; Knauss, 1987). The younger generation, in particular, lacked the institutional memory of those living under colonization and were more concerned with securing a job, finding decent housing, and continuing their education (Knauss, 1987). The post-independence generation was plagued by unemployment and underemployment, high government deficits in state-run industries, and rampant corruption (Layachi, 2001; Knauss, 1987). Therefore, generational cleavages were exacerbated by the unstable socio-economic conditions.

Like the other cleavages, generational cleavages were made further salient by class-based cleavages (Layachi and Haireche, 2001; Bensmaia, 1997; Chhibber, 1996; Tahi, 1995; Entelis, 1992). Specific class-based division include the educated versus non-educated; employed versus the unemployed (Tahi, 1995) and the educated employed versus the educated non-employed; middle-class versus lower socio-economic class (Chhibber, 1996); and, finally, intellectual elites versus professional elites (Bensmaia, 1997). These cleavages were also exacerbated by the unstable socio-economic conditions.

In conclusion, social crises exacerbated social cleavages, which created shared identities among the activists that created the FIS. The European paradigm did not provide propositions regarding the type of cleavages made salient. The FIS identified ethno-religious, gender, geographical, generational and class-based cleavages. According to the paradigm, these 
cleavages should have created a shared identity among the activists that mobilized to create the FIS.

FIS Identity. For the paradigm, the shared identity among the FIS activists should overcome existing cleavages to promote unity. In Algeria, the rise of political Islam is rooted in French colonization. Two ideological variants, the Salafiyya tradition and the Muslim Brotherhood, represented political Islam under colonization and operated within, but separate from, the FLN. ${ }^{21}$ The Salafiyya tradition was comprised of two trends-the official leaders appointed by the FLN, who were veterans of the Association des Oulemas Musulmans Algerians (AOMA); and, the dissident AOMA veterans, who operated outside official Islam and attacked the moral decay of society and government corruption (Knauss, 1987). The Muslim Brotherhood in Algeria emerged in the 1960s and was also comprised of two trends-an international variant that was affiliated with the Muslim Brotherhood in Egypt; and, a local variant that was influenced by the former yet independent (Knauss, 1987). ${ }^{22}$ The FIS members were made up of the dissident AOMA members and the local trend of the Muslim Brotherhood, with the latter being dominant.

The FIS, according to one of its leaders Ali Ben Hadj, is a network comprising a multitude of Islamic associations for educating, raising the consciousness of the people, and engaging in politics (Islamic Salvation Front, 2003: xxii). In fact, quoting Ibn Khaldun, he said, “[p]olitics is a competition for the public good, not private property. It is one of many aspects of

\footnotetext{
${ }^{21}$ Outside of these two traditions but shaped by them, the Armed Islamic Unit (AIU) was created in the 1980s by disgruntled members of ALN and FFS, both of which were members within the FLN network. While AIU initially challenged the FLN politically from within, it officially joined the FLN network in 1987 (International Crisis Group, 2004).

${ }^{22}$ From the 1960s to 1981, the Brotherhood existed as a social welfare organization that provided welfare, education, health and economic services and implemented programs to distribute clothes and water. The Brotherhood did not begin taking on a more political role until 1981, which was limited to lobbying government officials on issues related to education and family (Knauss, 1987).
} 
collective worship of God that brings great benefits” (Islamic Salvation Front, 2003: xxiv). Consequently, the FIS, founded in March 1989, was legalized as a political party in September of that same year. In June 1990, the FIS won a majority in the communal and regional assemblies. It was also predicted to win the majority in the second round of parliamentary elections before they were cancelled by the military.

The roots of the FIS extend back to the period of French colonization, according to Mostafa Brahimi, a member of the FIS (Islamic Salvation Front, 2003). In fact, the FIS leader, Sheikh Abassi Madani, participated in both the 1945 and 1954 rebellions. Even the members too young to participate in the rebellion were also affected. For example, Ali Ben Hadj, ${ }^{23}$ another top leader, was the son of an influential Mujahid in the National Liberation Army of the FLN and a student of other the FIS leaders that fought in the rebellion. Consequently, the discourse and identity of the FIS were nationalistic in nature. Since it was rooted in the period of French colonization, the discourse and platform of the FIS were also nationalistic. The use of nationalist themes thus resonated with those who grew up during the war of liberation and their children (International Crisis Group, 2004). ${ }^{24}$ The movement specifically referred to itself as being the son of the true FLN, referring to the FLN of the 1954 to 1962 period, which many of its members were part of at that time (Addi, 1994: 5).

In summary, the FIS utilized the existing cleavages that were exacerbated by socioeconomic crises to create a shared identity. While the paradigm does not posit the types of cleavages that activists utilize, the FIS case suggests that ethno-religious, gender, generation,

\footnotetext{
${ }^{23}$ Ben Hadj had a large following among the urban youth. He was arrested and charged with violating the security of the state in 1983. He was not released until December 1987. During the 1988 demonstrations, he led the people calling for peaceful demonstrations and for the right of the people to choose their destiny.

${ }^{24}$ FIS name originated from the Algerian nationalist movement.
} 
geographic and class-based cleavages provide a shared identity. For the FIS, ideology also played a role in the creation of a shared identity among movement activists. In particular, it was able to create an ideological niche by discursively linking itself to the 1954 Rebellion and the historical FLN of the 1954 to 1962 period. This resulted in creating ideological linkages to elites within the FLN. Its platform and policies, discussed in the American paradigm section, also linked the FIS ideologically to all of the existing social cleavages. Moreover, its membership was composed of all segments of society, including male, female, all socio-economic classes, and from all geographical areas. All of these factors created a shared identity among FIS activists and their constituency. Shared identities, according to the paradigm, produce mobilization to effect relations of domination.

Domination. The types present included bureaucratic domination, which had its roots in the petty bourgeoisie class created under French colonization (Brett 1994); political domination of one-party rule, which was also referred to in the literature on Algeria as authoritarian domination (Alexander 2002); and, finally, military domination (International Crisis Group 2000). These types of subordination provided a link or shared sense of solidarity among the existing social identities in Algeria. The FIS, based on its political platform, was created for addressing all three types of domination. In particular, the FIS was created to restore Algerian sovereignty by ending the military dictatorship and government corruption (Islamic Salvation Front, 2003: 73). The FIS case confirms the paradigm's proposition that mobilization is to effect relations of domination.

Choice of Action. The paradigm posited that the relations of actors to the environment and their goals determine the possibilities and the limits of action. The FIS defined itself as a political opposition party and not a resistance movement. It neither rejected the Algerian state 
nor called for the overthrow of the existing governance system or dominant political party. Instead, the FIS called for freedom of expression and equal access to and representation in the existing political system. Consequently, its goals were an end to political domination and restoration of Algerian sovereignty. Given this, violent protest would not have been an option. The majority of the FIS was comprised of activists from the Muslim Brotherhood tradition, which rejected violence as a form of protest. This helps to explain the form of non-violent protest adopted by the activists in the October 1988 protests. Even the minority, represented by the AOMA tradition, never advocated the use of violent protest. Activists from both traditions had operated within the FLN party system prior to 1988. The state's emphasis on the Muslim identity helps to explain their legal participation inside conventional politics. Finally, the opening of the Algerian governance system to reflect structural differentiation made participation in the form of conventional politics possible.

In summary, the paradigm predicted that existing conflict exacerbated social cleavages to create a shared identity. The examination of the FIS demonstrated that crises exacerbated existing social cleavages to create a shared identity among activists. From these cleavages, the FIS was able to develop a shared identity among not only activists but also its constituency. These activists mobilized to create the FIS for effecting relations of political domination. The creation of a shared identity was thus necessary for FIS mobilization.

\section{Conclusion}

This chapter sought to examine the mobilization of the FIS from within the American and European paradigms. These paradigms are theoretical frameworks that exist within the social movement literature to explain movement mobilizations, each positing very different explanatory variables. The American paradigm posited that the existence of socio-economic crises, 
deprivation and less structural differentiation in Algerian society provided political opportunities for the FIS to use, which enabled its mobilization. The European paradigm, on the other hand, posited that the existence of conflict would exacerbate social cleavages within Algerian society to create shared identities among FIS activists, which would enable the movement's mobilization. As already discussed, conflict was not present but socio-economic crises were, which had the same affect as the variable posited by the paradigm. This suggests that crises and conflict in the European paradigm have a similar affect on mobilization.

Given that both paradigms provided explanations for the FIS mobilization, an argument can be made for the generality of the paradigms. An argument can also be made for an integrated approach. The FIS would not have been able to mobilize without shared identities among its activists and those identities being rooted within existing social cleavages. Moreover, its mobilization would not have been possible without the political opportunities that were provided by the existence of socio-economic crises, deprivations, and less structural differentiation. 


\section{Chapter 4}

\section{Mobilizing the Islamic Jihad and Hamas in Palestine}

This chapter examines the cases the Islamic Jihad Movement and the Hamas. The Islamic Jihad mobilized in 1980. Hamas mobilized at the time of the Intifada in 1987. Both movements are rooted in and shaped by the historical development of a Palestinian national consciousness, as the first section demonstrates. Understanding the development of national consciousness is necessary to understand the mobilization of Islamic Jihad and the Hamas.

\section{Brief History of Palestinian National Consciousness}

After the fall of the Ottoman Empire, Palestine came under the control of the British. During the mandate period, the British had simultaneously promised the Arabs and Jews the creation of a state in the same territories due to their help fighting the Turks. ${ }^{25}$ This simultaneous promise fueled the armed resistance that broke out between the Arabs and Jews. The British turned the Palestinian issue over to the United Nations in 1947. The UN approved the partitioning of the territory into two states, one for Arabs and one for Jews. The leaders of the Arab governments rejected this and Israel declared independence, which resulted in the 1948 Arab-Israeli war.

Israel's victory resulted in it capturing a significant portion of the territory. The 1948 war and Israel's victory was significant because it resulted in the mass exodus of Palestinians from their homes. The mass exodus of Palestinians is significant for understanding the development of Palestinian consciousness for two reasons. First, the mass exodus of Palestinians helps us to understand why many of the movements that formed in the 1950s and 1960s were created

\footnotetext{
${ }^{25}$ See Khalidi (1997) for a more detailed history of this period.
} 
outside rather than inside the territories. Relatedly, the development of movements outside the territories prevented the formation of a unified Palestinian front between Palestinians living inside and outside the territories. This helps explain why it took so long for a Palestinian national consciousness to develop.

To understand the development of a Palestinian national consciousness, Lisa Taraki (1990) posits that it is necessary to go back two decades before the Intifada in 1987 . A Palestinian consciousness is the idea that the establishment of a Palestinian national authority by itself can fulfill national aspirations. Palestinian consciousness, Taraki argued, was the product of the convergence of many factors and events including: the ambivalent position of Arab governments, the rise of Palestinian resistance in the 1960s, the growth of the Palestinian Liberation Organization (PLO), and, most importantly, the conditions of daily life under Israeli military occupation beginning in 1967 (Taraki 1990: 53).

Prior to 1967, the Palestinian cause and identity were not articulated in distinctly Palestinian organizations. They were articulated in terms of Arabism, which, according to Rashid Khalidi, is the belief in the notion that "Arabs were a single people with a single language, history, and culture, divided not by centuries of separate development of widely separated countries, but by the recent machinations of imperialism” (Khalidi, 1997: 131-133). The pan-Arab nature of the Palestinian identity provided a larger sense of identity, which gave the perception of a promise of protection from external, or at least regional, pressures (Farsoun and Zacharia 1997). The failure of pan-Arabism, however, is what turned the Palestinian identity inward to emphasize its Palestinan-ness and toward nationalistic groups (Taraki, 1990).

Not only did the failure of pan-Arabism aid in turning Palestinian identity inward, but so too did the collapse of the United Arab Republic in 1961 and the independence of Algeria in 
1962 (Nassar and Heacock, 1990). The success of the Algerian Muslim Rebellion was significant because it influenced Fatah’s armed struggle from 1964-1965 and the Uprising of 1966, which in turned influenced the separation of Palestinian identification from a larger Arab identity, and from Arab governments, Jordan's in particular. Finally, the Arab-Israeli war of 1967 solidified a distinct Palestinian identity and reconciled divisions between Palestinians inside and outside the territories.

Following the Arab-Israeli war of 1967, Israeli military occupation of the Palestinian territories led to armed resistance and the start of Palestinian political mobilization (Taraki, 1990: 55). Mobilization outside the territories, led by Fatah and the Popular Front for the Liberation of Palestine, sought to create a popular revolutionary movement that would unite Palestinians living inside and outside of the territories. Given their location outside of the territories, they were unable to mobilize Palestinians living in the West Bank. Gaza, however, was a different story. Palestinians living in Gaza had been trained by the Egyptian military (Farsoun and Zacahria, 1997), which created conditions that led to both violent and non-violent protest against Israeli forces in Gaza from 1967-71. By 1971, Israel had defeated Palestinian resistance in Gaza, and Jordan had suppressed resistance led from its territories.

However, in retrospect we see that the quashing of Palestinian resistance by both Israel and Jordan was important to the development of Palestinian national consciousness. The increasing presence of Israelis living inside the occupied territories heightened Palestinian identity. For the first time Palestinians spoke out for the creation of an independent, sovereign entity to call home. Previously, Palestinian resistance movements called for a return to the status quo- those in the West Bank had previously called for a return to Jordan, whereas those in Gaza 
had called for a return to Egypt. The call for an independent state came with the creation of the PNF (Farsoun and Zacharia, 1997; Taraki, 1990).

The creation of the PNF, therefore, was the culmination of a Palestinian national consciousness. Moreover, the PNF was able to unite Palestinians inside and outside the territories behind a campaign of civil disobedience. It aided in the development of a distinct Palestinian civil society to foster self-reliance. The PNF was more successful than past attempts at mobilization due to its coordination of those both inside and outside the territories. Its youth programs such as the Voluntary Worker Movement were also important in this effort. The Voluntary Worker Movement was significant for several reasons. First, it was the only substantial community effort to bring both young men and women together. Secondly, it was the first time an organization overcame the barrier between many societal cleavages, namely divisions between the intellectual and working classes, the urban and rural areas, and the middle and lower socio-economic classes. Finally, it served as the springboard for other cultural programs. The movement was able to operate unhindered by the occupying authorities due to its apolitical nature. It was not until 1976 that the Israelis began to crackdown on its operation, when the movement mobilized Palestinians for the municipal elections held in the West Bank (Farsoun and Zacharia, 1997; Taraki, 1990).

Despite the crackdown by the Israeli military authorities, the institutional framework established during the early 1970s assisted in the building of a non-clandestine national movement in the late 1970s. This period saw the creation of open frameworks for political, social and cultural action; the amplification of mass participation; and, the incorporation of new social forces, particularly in the lower socio-economic classes, into Palestinian institutional life (Taraki, 1990: 60). The mass organizations created during this period were designed to 
incorporate and mobilize large numbers of Palestinians from all lifestyles and occupations in a decentralized structure that permitted democratic decision-making (Farsoun and Zacharia, 1997; Taraki, 1990). These mass organizations were responsible for creating national institutions to be subsumed under an eventual Palestinian state (Taraki 1990: 66). The development of national institutions created a dual infrastructure within the Palestinian territories, one under the control of the occupying authorities, and the other controlled by Palestinians (Farsoun and Zacharia, 1997). While the dual infrastructure created by Palestinians inside the territories existed, a quasigovernmental infrastructure would not be established until the 1990s. This was due to the fact that from 1967 until the 1990s, the territories were not autonomous; they were governed by the Israel military.

The creation of a dual institutional infrastructure, however, resulted in the consolidation of the Palestinian national movement and the expansion of its social base in the 1980s (Farsoun and Zacharia 1997; Taraki 1990). It was also in this period that the Islamic movement began to develop its national identity which was separate from that of the national movement that had developed over the years (Taraki, 1990: 67). The Islamic movement, which was comprised of multiple identities but dominated by the Muslim Brotherhood in the West Bank and Gaza, ${ }^{26}$ had been active in Palestinian society since the early 1930s. Until the 1980s, it was limited to religio-cultural and social issues. The Islamist movement influenced Palestinians inside the territories because it provided financial support and social services to large segments of the

\footnotetext{
${ }^{26}$ The Muslim Brotherhood in the West Bank and Gaza was separate from the Muslim Brotherhood in Egypt created by Hasan al-Bana. While independent thereof, it was connected to the Egyptian Brotherhood. Being a member of the Brotherhood entails the prohibition against violent resistance, which is why a separate organization, Hamas, was created in 1987. Consequently, Hamas has its origins in the Brotherhood, but it separate from the organization. Its adoption of violence resistance meant that it could no longer be an organization within the Brotherhood network. See Abu Amr (1994), El Awaisi (1998) and Mishal and Sela (2006).
} 
disaffected population. Moreover, due to the Brotherhood's apolitical nature ${ }^{27}$ from the 1930 s to 1987, it operated almost unhindered by the military authority.

Even in the 1980s, the Islamic movement was not interested in creating and gaining control of organizations and institutions; it was not concerned with political power. ${ }^{28}$ Its main ambition was the formation of Islamic blocs at universities, youth associations and charitable societies (Taraki, 1990: 67). While the Brotherhood remained apolitical, it was a different story for members of the Islamist bloc in Gaza. It was in Gaza at the Islamic Center and Islamic University that dissemination of an Islamic political thinking was the intent. Consequently, it was in Gaza that Islamic organizations separate from the Brotherhood developed, namely the Islamic Jihad movement.

The development of a Palestinian national consciousness is reflected in the various movements that developed over the years. Palestinian representation was spread among a diverse set of groups: the PLO, the Palestinian Liberation Army (PLA), the Palestinian Resistance Movement (PRM), the Fatah, the Popular Front for the Liberation of Palestine (PFLP), the Democratic Front for the Liberation of Palestine (DFLP), and the Palestinian Communist Party (PCP), which later became the Palestinian People's Party (PPP). With the exception of the PRM, all of these movements developed outside the Palestinian territories. In this way they were significantly different from the Islamic Jihad and Hamas, which developed inside Palestinian territories and refused to join the PLO (Abu Amr, 1994).

Fatah and the PFLP developed in the 1950s. Fatah was created as an armed resistance movement, with no political ideology outside of the liberation of Palestine. Unlike the PFLP,

\footnotetext{
${ }^{27}$ See Abu Amr (1994), El Awaisi (1998), and Mishal and Sela (2006) for the apolitical nature of the Brotherhood in Palestine.

${ }^{28}$ Again see Abu Amr (1994), El Awaisi (1998) and Mishal and Sela (2006) regarding the claim that the Islamic movement was not interested in creating and gaining control of organizations and institutions or in gaining power.
} 
Fatah was not a grass-roots resistance movement that worked from the bottom-up. Instead, it was hierarchical and worked primarily with Arab governments and institutions. Unlike Fatah, the PFLP was an underground-armed resistance movement and political organization that called for revolution in the entire Arab world. In contrast to Fatah, the PFLP was much smaller in actual numbers but carried greater influence among Palestinians due to its underground political organization. The PFLP was initially a pan-Arab party that transformed itself into a MarxistLeninist party in 1967. This ideological transformation resulted in the fragmentation of the group and resulted in the creation of DFLP. The DFLP, founded in 1969, is more orthodoxMarxist and calls for the creation of a non-sectarian, secular state, where all citizens are equal. Despite ideological fragmentation, these groups worked at the grassroots level in the refugee camps outside of the territories in an attempt to build bridges with other Palestinian opposition parties and movements. When Fatah and the PFLP joined the PLO in 1968, they became its two largest parties.

The PLO was created in 1964 by the Arab governments and Palestinians living outside the occupied territories. At its creation, it was comprised of the Palestinian National Council (PNC), which was the executive arm, and the Palestinian Liberation Army (PLA), which was the main armed wing. ${ }^{29}$ From its creation until 1993, the PLO had no physical presence in the Palestinian territories. $^{30}$ The PLO, however, was the first Palestinian movement to call for an independent Palestine, mandatory conscription, and freedom of political action. Consequently, it influenced the resistance movements that emerged inside the territories in the 1980s.

\footnotetext{
${ }^{29}$ It is interesting to note here that former members of the PLA comprise a large segment of the Islamic Jihad. See the section on PIJ Identity for more information.

${ }^{30}$ See Farsoun and Zacharia (1997) for an extensive history of the PLO.
} 
The largest movements to develop during the period in which Palestinian consciousness was developing were the Palestinian Arab National Union (PANU) and the Palestinian Resistance Movement (PRM). Created in Gaza in 1964, PANU was an above-ground political resistance movement affiliated with the PLO. Its purpose was to issue leaflets in an attempt to garner support for the PLO among Palestinians living in the territories. PANU did not last long due to repressive Israeli military policies. The PRM also emerged in 1964 as an underground movement located in Gaza. Its purpose was armed resistance against Israel. The PRM merged with the PLO in 1968, after the 1967 Arab-Israeli war. This merger was significant because it led to reconciliation between groups inside and outside the territories; and, it separated the Palestinian movements from the Arab states.

However, reconciliation between groups inside and outside the territories did not last long due to Israeli military policies, which, among other things, quashed the PRM. The reconciliation of outside movements remained intact, and was reflected in the PNC Charter of 1968, which joined Fatah, the PFLP, the DFLP, the PFLP-GC, the PCP (later PPP) ${ }^{31}$ and other smaller organizations with the PLO. Despite reconciliation of the movements on the outside, the PLO continued to be plagued with problems due its functional bodies being elitist, hierarchical, and failing to mobilize Palestinians inside the territories. It was not until 1993, with the signing of the Oslo Accords, that the PLO entered the territories.

In conclusion, mobilization has historically occurred outside of the Palestinian territories. The mobilization outside is in part a product of the Arab-Israeli wars of 1948 and 1967. For the two larger movements, PANU and PRM, their mobilization inside the territories in the 1960s

\footnotetext{
${ }^{31}$ The Palestinian Communist Party (PCP) was created in 1951. It became inactive in 1967, but was reconstituted in 1987 under the Palestinian's People Party (PPP). Ideologically, it is a combination of the centrist Fatah faction and the DFLP.
} 
was short-lived because of Israeli military policies and military governance. All of these historical movements utilized crises, deprivation, conflict, structural differentiation and political opportunities to mobilize. The rise of these movements in the 1960s, despite their mobilization on the outside, was influential to those movements that emerged inside the territories in the 1980s.

The mobilization of the movements in the 1960s was influential in the sense that it helped in the development of a Palestinian national consciousness. It is a Palestinian national consciousness that gave rise to the mobilization of movements inside the territories, notably the PIJ and Hamas. These movements therefore, are very much a part of the Palestinian national framework. They are different from their predecessors in that they mobilized inside rather than outside the occupied territories. The activists of the PIJ and Hamas were the children of the period of Israeli military occupation.

\section{Mobilization from the American Paradigm}

The conditions that led to the mobilization of the PIJ and Hamas were not the same as when the PLO and the other movements mobilized. ${ }^{32}$ This is largely because the PLO did not exist inside the Palestinian territories until 1993, after the signing of the Oslo Accords. The PLO did not directly experience the conditions of military occupation. The signing of the Accords in 1993 is what established the Palestinian Authority. The creation of the Palestinian Authority began the period of transition from military governance to Palestinian governance of the territories. The period at the time of the PIJ and Hamas mobilization was characterized by socioeconomic crises, deprivation, and a lack of structural differentiation. According to the American paradigm, crises, deprivation, and level of structural differentiation do not cause mobilization.

\footnotetext{
${ }^{32}$ Since all the movements that mobilized outside the territories joined the PLO in 1968, the use of “the PLO” will refer to all of these movements as a collective unit.
} 
Rather, they provide political opportunities for activists to utilize. For the American paradigm, the role of the activists enables mobilization. This section examines the enabling explanatory variables and the way activists utilize them to explain the mobilizations of the PIJ and Hamas.

Socio-Economic Crises, Deprivation and Structural Differentiation. Crises in the form of unstable socio-economic conditions were present when both the PIJ and Hamas mobilized (United Nations Conference on Trade and Development). After 1967, the Palestinian economy was dependent on the Israeli economy. The following chart provides inflation rates for the Gaza Strip, the West Bank and Israel from 1971 to 1991. Inflation, according to Blejer and Guerrero (1990), are a measure for crises because the disaffected are unable to protect their real incomes.

\begin{tabular}{|c|c|c|c|}
\hline \multicolumn{5}{|c|}{ Table 4.1. Palestinian Inflation Rates } \\
\hline Year & $\begin{array}{c}\text { Gaza } \\
\text { Strip }\end{array}$ & $\begin{array}{c}\text { West } \\
\text { Bank }\end{array}$ & Israel \\
\hline 1971 & 22 & 16 & 12 \\
\hline 1975 & 54 & 43 & 39 \\
\hline 1981 & 110 & 114 & 117 \\
\hline 1985 & 338 & 321 & 305 \\
\hline 1991 & 7 & 12 & 19 \\
\hline \multicolumn{4}{|l}{ Source: Hijjeh 1998} \\
\hline
\end{tabular}

The economic crises in the territories from 1967 to 1987, according to Yiftachel (1997) and Khawaja (1994), were a product of political instability due to the Palestinian-Israeli conflict. The conflict negatively affected the economy and caused crises because Palestinians were dependent on Israel granting them work permits to enter Israel, as well as permits to move through checkpoints within the West Bank and Gaza, and on Israeli soldiers keeping checkpoints open and permitting access (Khalidi, 1998; Farsoun and Zacharia, 1997). The economy during this period was also constrained by Israel permitting the inflow and outflow of goods and services (Farsoun and Zacharia, 1997). During times of high-intensity conflict between the Palestinians and Israelis, Israel prohibited the flow of goods and services (Khalidi 1998; Farsoun 
and Zacharia, 1997; Khawaja, 1994). Crises contributed to large segments of the Palestinian population becoming disaffected, which resulted in widespread deprivation (Yiftachel, 1997; Khawaja, 1994).

According to the American paradigm, crises led to deprivation (Yiftachel, 1997 and 1992; Zureik, 1993; Haidar, 1991). Deprivation was present prior to and at the time when both the PIJ and Hamas mobilized (Yiftachel, 1997; Khawaja, 1994). Deprivation was due to the Palestinian perception that occupation, and the Israeli military governance of the territories, hindered economic development and caused an uneven distribution of resources (Yiftachel, 1997 and 1992; Zureik, 1993; Haidar, 1991). Perceived deprivation was more important because Palestinians believed "they had been subjected to continuous policies of control and discrimination, including military rule and forced transfer of lands to [Israel], and a persistence of socio-economic and power disparities between [Palestinians] and [Israelis]” (Yiftachel, 1997: 97-98).

The actual policies of Israel in this period contributed to the perception of deprivation. For example, Israeli land policies resulted in the loss of a major source of livelihood for Palestinians. Palestinian society was mainly agrarian, with most living in villages (Yiftachel, 1997; Rubenstein, 1990). ${ }^{33}$ Another example relates to the Israeli policy of “Judaising” (Soffer and Finkel, 1989), which was implemented in response to the decisive Arab majority in the region and the expanding Palestinian population (Schnell, 1994). Finally, Israeli immigration policy provided financial benefits, separate roads, and a better quality of life to Jewish immigrants willing to settle in Palestinian territories (Yiftachel, 1997; Carmon et al., 1991;

\footnotetext{
${ }^{33}$ Land is important to both Palestinian culture and identity, which is most evident in the Palestinian national anthem, "My Land." Consequently, Israeli attempts to de-territorialize Palestinians with her socio-economic and security policies exacerbates perceived land deprivation, which is made more salient by actual loss of land and regional cohesion (Yiftachel, 1997; Rubenstein, 1990).
} 
Falah, 1990). Deprivation was also heightened due to no access to government institutions. Palestinians were not able to challenge any of these policies due to the lack of structural differentiation.

According to the American paradigm, structural differentiation is important because it determines whether activists have access to the government to redress the causes of deprivation. From 1967 and until the signing of the Oslo Accords in 1993 there was no Palestinian autonomous governance structure. During the period from 1967 to 1993, it was under the direct governance of the Israeli military. Israeli military administration resulted in the implementation of Israeli law, jurisdiction, and public administration in the West Bank and East Jerusalem and in the Gaza Strip (Farsoun and Zacharia, 1997). Separate military administrations were established in the West Bank and Gaza, but both were united under the direct control of the Israeli minister of defense.

The lack of structural differentiation, and military laws prohibiting Palestinians from forming political collectivities, prevented legal challenges to the status quo within conventional political boundaries (Nasser-Najjab, 2005; Farsoun and Zacharia, 1997; Khawaja, 1993; Taraki, 1990). Political institutions inside the territories were not adaptable, coherent, or autonomous; they were not free from the control and manipulation of the Israel military (Farsoun and Zacharia, 1997; Khawaja, 1993; Taraki, 1990). Through these institutions, Israel provided basic resources to Palestinians for subsistence (Farsoun and Zacharia, 1997). The inability to legally challenge military policies or to participate in the governance of the territories, and the lack of resources needed for subsistence, led Palestinians to found civil society organizations. Until 1987, these were apolitical (Nasser-Najjab, 2005). Due to their apolitical nature, Israel tolerated their existence and operation. Those perceived by Israel as being political or quasi-political in 
nature were shut down and organizers imprisoned or exiled. Civil society organizations, especially those affiliated with the Muslim Brotherhood in Palestine, provided socio-welfare resources to society (Nasser-Najjab, 2005). The development of civil society was thus vital for providing political opportunities (Nasser-Najjab, 2005; Farsoun and Zacharia, 1997).

In conclusion, the lack of structural differentiation between 1967 and 1987 resulted in the development of civil society organizations outside conventional political boundaries. Civil society organizations were a product of crises, which caused widespread deprivation. Political mobilization inside the territories from 1967 to 1987 was limited due to repressive measures. Repressive tactics included, but were not limited to, discriminatory policies ${ }^{34}$ (Farsoun and Zacharia, 1997; Taraki, 1990) and human rights abuses ${ }^{35}$ such as violence, imprisonment and exile (Khawaja, 1993). From 1980 to 1983, the period in which PIJ mobilized, there was not widespread use of repression by the Israeli military authority. Imprisonment for nonviolent political activity was limited, though those affected experienced torture and beatings (Political Terror Scale). The limited use of repression by the military authority was attributed to the absence of armed resistance inside the territories. During this period, the PLO from outside the territories was waging armed resistance. ${ }^{36}$

From 1984 to 1987, there was not widespread use of repression, but there was an increase in its use (Political Terror Scale). In particular, there was extensive political imprisonment, brutality, and unlimited detention. There were also political executions. The increase in the use

\footnotetext{
${ }^{34}$ Discriminatory policies included: a prohibition on the right to express dissent and the formation of political collectivities; hindrance on freedom of movement by checkpoints, the permit system, and curfews; the issuance of identity cards and registration of all Palestinians with the military; Israeli employment practices and settlement policies; and, the uneven distribution of basic services such as health and education (Farsoun and Zacharia, 1997).

${ }^{35}$ Human rights abuses such as violence and imprisonment occurred among those who attempted to express political dissent within the public sphere (Khawaja, 1993).

${ }^{36}$ See the historical section for a list of the Palestinian factions that joined the PLO in 1968. Those factions and the PLO began engaging in armed resistance from outside of the territories in 1967.
} 
of repression was attributed to the beginning of violent and non-violent resistance occurring in the territories. Although the PIJ did not engage in armed resistance at its creation in 1981, it began engaging in armed resistance in 1984 (Hatina, 2001). ${ }^{37}$ The start of a violent and nonviolent resistance campaign inside the territories in 1984 followed a decline in resistance activities led from the outside by the PLO and its factions (Farsoun and Zacharia 1997).

From 1967 to 1987 there were socio-economic crises, deprivation, and a lack of structural differentiation. Although repression was not widespread, it was present. There were no changes in the level of Israeli elite receptivity or the implementation of policies to alleviate some of the repressive measures of occupation inside the territories (Farsoun and Zacharia, 1997; Khawaja, 1993). It is in these conditions that the PIJ and Hamas mobilized. The American paradigm posited that crises, deprivation, and structural differentiation do not cause mobilization. Instead, they are enabling factors that provide political opportunities for the activists to use for mobilization. The following sub-sections examine the movements' use of these opportunities separately.

The PIJ's Use of Political Opportunities. The activists that created the PIJ utilized the political opportunities provided by the lack of structural differentiation, lack of access to governance structures, lack of ability to form political parties or quasi-political collectivities to challenge the governance structure, and the use of repression. Activists only indirectly used socio-economic crises, deprivation and the inadequate provision of and access to resources. The purpose of the PIJ was to engage in resistance to obtain an independent sovereign state. The creation of a Palestinian state in the territories encompassing the West Bank, Gaza, and East Jerusalem, according to the PIJ member Nafidh Azzam, is acceptable so long as Palestinians

\footnotetext{
${ }^{37}$ See Hatina (2001) for a description of the PIJ’s non-violent resistance activities from 1981 to 1983 and violent resistance activities beginning in 1984 .
} 
have full sovereignty and control over their own security (Azzam, 2004). At the time of mobilization, the activists of the PIJ were responding to the lack of structural differentiation in the territories governed by the Israeli military since 1967. The PIJ, in the absence of sovereignty, would take part in municipal elections and vote in legislative and presidential elections under an autonomous governance structure (Azzam, 2004). Participation, such as registering for and voting in elections, is an important domestic duty for formulating the Palestinian agenda and building a society based on justice, freedom, and dignity (Marzouq, 2007; Azzam, 2004). Through this policy position, the activists were utilizing the lack of autonomous political institutions and access to governance structures.

Activists utilized the lack of ability for political parties or quasi-political collectivities to form, participate and challenge the governance structure. In particular, they used it to justify the adoption of resistance. The use of resistance, according to the elected leader of PIJ, "is a legitimate right guaranteed by all divine and earthly laws for people [that are] subjected to foreign invasion or occupation” (Shallah, 1999). Resistance implies not only armed conflict, but also non-violent protest (Hatina, 2001). Armed conflict, according to the PIJ, cannot be used until the conditions are ripe and society is ready (Hatina, 2001). This is the reason why the PIJ did not engage in armed conflict at its mobilization and instead engaged in non-violent protest over the absence of a Palestinian state. Finally, the activists used the governing authority's use of repression. Resistance, according to the PIJ, is necessary as long as Israel continues its use of repression, including its policies of assassinations, killings, demolition of houses, and arbitrary arrests and detentions (Shallah, 1999). A couple of years after the PIJ's mobilization, the use these tactics would provide justification for the adoption of armed resistance. The PIJ activists did not directly use the opportunities provided by the lack of adequate provision of and access to 
resources. Rather, they indirectly used these as political opportunities. Activists indirectly used them by relying on the linkages created with the Muslim Brotherhood in Palestine, which had established extensive social service networks throughout the territories (Abu Amr 1994). By creating linkages between the constituents of the Brotherhood, the activists of the PIJ also utilized socio-economic crises and deprivation.

In summary, the PIJ directly and indirectly utilized all the political opportunities provided. In particular, it indirectly used the opportunities provided by crises, deprivation, lack of access, and the inadequate provision of resources by the Israeli government. It directly used the lack of structural differentiation and the absence of autonomous political institutions. Consequently, the PIJ case confirms the American paradigm's proposition that movements utilized political opportunities to mobilize. It does not confirm the proposition that the political opportunities were utilized to create linkages between individuals, institutions and organizations. For the PIJ, the creation of linkages merely served as a political opportunity for activists to use crises and deprivation for mobilization.

Hamas' Use of Political Opportunities. The activists that created Hamas utilized the political opportunities provided by lack of structural differentiation, lack of access to governance structures, and lack of ability to form political parties or quasi-political collectivities to challenge the governance structure. In contrast to the PIJ, Hamas activists directly used political opportunities provided by socio-economic crises, deprivation, and the inadequate provision of and access to resources. Hamas activists did not use the political opportunity provided by the existence of repression. The creation of Hamas, according to member Mahmoud Zahar, was for the attainment of a sovereign state wherein Palestinians could “enjoy freedom, independence and a dignified life with [its] neighbors in this Holy part of the world” (International Crisis Group, 
2006). Similar to the PIJ, the creation of a state encompassing the territories of the West Bank, East Jerusalem, and Gaza was sufficient. It differed from the PIJ by further stating that the creation of a state, so defined, would be acceptable as long as all Palestinians voted for this option. Hamas’ purpose, according to member Riad Mustafa, was to end occupation, and not the destruction of Israel (Rudolph and Van Engeland 2008). The existence of Israel and its recognition by other states is a reality, according to Hamas member Ismail Haniyya. Through Hamas' policy position, activists were referring specifically to the lack structural differentiation and the inability of Palestinians to participate in the governance of the territories. Participation of its members in society at-large is an important Islamic duty (Tamimi, 2007). These positions particularly resonated with Palestinians living inside the territories, who had been subjected to military governance beginning in 1967.

In contrast to the PIJ, Hamas activists utilized the opportunities provided by the inadequate provision of and access to resources. Activists were able to utilize these due to them inheriting the infrastructure established by the Brotherhood. The Muslim Brotherhood in the West Bank and Gaza built an extensive social-services network within the Palestinian territories, beginning in the 1930s. Through its inheritance of the Brotherhood's social services infrastructure, Hamas was able to provide needed resources to Palestinian society such as healthcare, employment, education scholarships, and training programs to help families become self-sufficient. It is through the provision of resources that Hamas activists were able to create linkages between individuals, organizations and institutions and establish a support base inside the territories.

In summary, Hamas activists utilized the lack of structural differentiation, lack of access to governance structures, and lack of ability to form political parties or quasi-political 
collectivities to challenge the governance structure. Finally, Hamas activists also used the political opportunities provided by socio-economic crises, deprivation, and the inadequate provision of and access to resources. These opportunities were utilized for engaging in resistance. Hamas, according to its elected leader, Khaled Mish'al, "is committed to restoring the natural rights of the Palestinian nation and to liberate all of the occupied territories, including occupied [East Jerusalem] and the repatriation of the refugees” (Rudolph and Van Engeland, 2008; International Crisis Group, 2006). Only resistance could obtain the restoration of the natural rights of Palestinians because of the lack of structural differentiation and access to governance structures. The form of resistance adopted at its founding was strikes, demonstrations, and graffiti wars (Tamimi, 2007; Abu Amr, 1994). Hamas' use of political opportunities, with the exception of the use of repression, confirms the American paradigm's proposition. In particular, it confirms the proposition that activists utilize political opportunities to create linkages between individuals, institutions, and organizations to mobilize.

The PIJ's and Hamas' Choice of Action. Whether action takes place inside or outside conventional boundaries, according to the American paradigm, depends on greater or less openness/access (Structural differentiation) and political opportunities (Meyer, 1999; Tarrow, 1992; Tilly, 1978; Eisenger, 1973). In the cases of the PIJ and Hamas, there was less structural differentiation and political opportunities available at the time of their mobilization. Their mobilization occurred outside of conventional political boundaries. These cases, therefore, confirm the proposition that the lack of structural differentiation and political opportunities explain participation outside conventional political boundaries. 


\section{Mobilization from the European Paradigm}

In the 1960s, the Arab-Israeli conflict exacerbated existing social cleavages. The cleavages created a shared identity among Palestinian activists that formed Palestinian resistance movements outside of the territories. These activists mobilized to affect relations of domination. The mobilizations of the PIJ and Hamas were also made possible by the creation of a shared identity among activists. For the European paradigm, it is the creation of a shared identity that produces mobilization and not activists' use of political opportunities. Therefore, this section examines the role of identity in the mobilizations of the PIJ and Hamas.

Conflict and Cleavages. The European paradigm posits that the presence of conflict exacerbates existing social cleavages. Armed conflict was present when the PIJ and Hamas mobilized (Uppsala Conflict Database). At the time the PIJ mobilized armed conflict was occurring between the PLO and its factions outside of the Palestinian territories. At the time Hamas mobilized there was armed conflict both inside and outside the territories. Since conflict was present prior to the mobilizations of both movements, that by itself cannot explain the exacerbation of existing social cleavages. Crises, as will be demonstrated, also contributed the salience of existing social cleavages. The salience of existing cleavages, according to the paradigm, provided a shared identity among activists.

Conflict (Karmi, 2003; Pfeifer, 2003) and socio-economic crises (Pfeifer, 2003) made salient ethnic, religious, generational, educational, geographical, urban-rural, socio-economic, income, class-based, occupational, and ideological cleavages. Ethnic cleavages inside the Palestinian territories exist between the Palestinian and the Jewish-settler populations (Flores, 2006; Pfeifer, 2003; Moore and Aweiss, 2002; Khawaja, 1994); and, within Israel proper, between the Jewish-Israeli population and the Arab-Israeli population (Shabaneh, 2007; Yiftachel, 1997). These ethnic cleavages further spillover into religious cleavages, but are more 
prevalent along the lines of the Jewish-settler or Zionism (Flores, 2006; Moore and Aweiss, 2002) and the Palestinian-Muslim population located inside Palestinian territory_West Bank and Gaza (Flores, 2006; Pfeifer, 2003; Moore and Aweiss, 2002). ${ }^{38}$ Geographical cleavages exist due to the presence of a settler population and Israeli policies ${ }^{39}$ that hinder freedom of movement and promote forced expulsion of Palestinians from their homes (Shabaneh, 2007; Karmi, 2003).

Generational cleavages, according to Karmi (2003), are sparked by children growing up seeing their parents helpless and perceiving them as being impotent to change existing environmental conditions. Consequently, the younger generation is more politicized and active than the older generation (Pfeifer, 2003). Educational cleavages are due to the inadequate educational system in the territories (Halstead and Affouneh, 2006). From 1967 to 1994, ${ }^{40}$ education was under Israeli control. It was characterized, according to Halstead and Affouneh (2006), by crowded classes, with too many students jammed into small classrooms, double-shift schools, lack of teacher training, inadequate instructional materials, and limited funds allotted for curricula improvements.

Urban-rural cleavages were created by new socio-economic and political classes replacing traditional socio-economic elites and political hierarchies (Farsoun and Zacharia, 1997). Socio-economic cleavages, according to Shabaneh (2007), were created by the constraints imposed on the physical expansion of Palestinians and by the weakening of

\footnotetext{
${ }^{38}$ Interestingly, in a study conducted by Moore and Aweiss (2002), it was demonstrated that both Palestinians and Israelis (those living within Israel proper) share a dislike of the Jewish-settler or Zionist population living inside Palestinian territories (West Bank and Gaza).

${ }^{39}$ Policies such as the checkpoints and the permit system prohibit Palestinians inside the territories from being physically connected to one another and to those on the outside (Shabaneh, 2007; Karmi, 2003).

${ }^{40}$ In 1994, responsibility for education was transferred from Israeli-centralized control to the Palestinian National Authority. Thus, the system inherited by the PNA was chaotic and disastrous at best.
} 
Palestinian society. The weakening of society resulted in Palestinian institutional frameworks being undermined; the deepening of the subordination of Palestinian existence to the Israeli judicial system; and, the minimization of Palestinian opportunities to utilize natural resources. Income cleavages led to class-based cleavages (Shabaneh, 2007). These were caused by more than half of the Palestinian population living below the poverty line. Consequently, the quality of living standards, education, and healthcare services are low.

Occupational cleavages inside and among Palestinian society include traditional, agrarian-based classes versus new intellectual and professional based classes (Khawaja, 1994) and, between laborers versus the professional class (Rosenfeld, 2004). Cleavages also exist between Israeli laborers (largely the immigrant community in Israel) and Palestinian laborers (Pfeifer, 2003). They exist between the Israeli intellectual and professional classes versus the Palestinian intellectual and professional classes Ideological cleavages, according to Flores (2006) and Moore and Aweiss (2002), were found to exist between Zionism, Arab-nationalism, and Islamic nationalism.

In conclusion, conflict and crises exacerbated existing social cleavages among Palestinians. The European paradigm did not provide propositions regarding the type of cleavages made salient. The cases of the PIJ and Hamas identified ethnic, religious, generational, educational, geographical, urban-rural, socio-economic, income, class-based, occupational and ideological cleavages. According to the paradigm, these cleavages should have created a shared identity among the activists that mobilized to create the PIJ and Hamas.

PIJ Identity. For the paradigm, the shared identity among the PIJ activists should overcome existing cleavages to promote unity. In Palestine, the rise of political Islam was attributed to two main developments in the 1970s. The first development was widespread 
discontent with secular-nationalism, represented by the PLO and its factions that were located outside of the territories (Hatina, 2001; Khalidi, 1997; Farsoun and Zacharia, 1997; Abu-Amr, 1994; Taraki, 1990). This development would not have been successful without the growing Islamic trend inside the territories, which had its ideological and socio-cultural basis in the Brotherhood. The second development was the success of the Islamic movements in Afghanistan, Iran, Egypt and Lebanon (Hatina, 2001; Abu-Amr, 1994). This development made political action seem more realistic for those within the Islamic bloc, who were discontented with the status quo. It is from this that the activists of PIJ emerged.

The role for political Islam and the identity of PIJ is historically rooted in the "failure of subservient and secular Arab regimes, the entrenchment of the Zionist entity in the heart of the Muslim region... and the shallow approaches of the Islamic movement and the PLO” (Hatina, 2001:49-50). The PLO was seen as nothing more than a tool for the Arab regimes to placate their own domestic populace. The Islamic movement was rejected for its passivity; in particular, its rejection of political Islam. The PIJ activists believed that the current conditions in Palestine required immediate political action and not passivity or subservience.

For the PIJ, the Palestinian problem could not be framed in the narrow context of Palestinian or Arab nationalism. Rather, it is "purely an Islamic issue," which required a commitment to two interrelated goals. Those goals were "the liberation of Palestine and a panIslamic revival in the region,” with the burden of the former placed on Palestinians and the latter on all Muslim countries (Hatina 2001: 51). For the PIJ, liberation does not mean the immediate use of armed struggle. According to one of the PIJ's founders, Fathi Shaqaqi, armed struggle only becomes necessary when the conditions are ripe and until then the goal of Palestinian Muslims is to prepare (Hatina, 2001). According to the elected head of PIJ's Politburo, Dr. 
Ramadan Shallah, the movement's strategic plan conforms to the history of the struggle of the Palestinian nation, which is to confront Israel ideologically, politically and militarily (Rudolph and Van Engeland, 2008). Resistance was not the main impetus for PIJ's emergence. The main impetus, according to the PIJ founder Fathi Shaqaqi, was the absence of Islam from Palestinian politics (Hatina, 2001: 26). Therefore, the main impetus for PIJ was ideological differentiation from secular-nationalism and the Muslim Brotherhood in Palestine.

Despite carving an ideological niche for itself within the status quo, PIJ has touted the importance of cooperation and dialogue with all Palestinians (Rudolph and Van Engeland, 2008). To promote cooperation and dialogue activists sought and maintained existing ties to all Palestinian movements in the territories. ${ }^{41}$ The best opposition methods to the political line taken by other factions, according to the PIJ, are dialogue and criticism. Outside cooperation and dialogue, the PIJ has no specific policies for socio-economic and political development to differentiate itself from the PLO or others (Hatina, 2001). Therefore, unlike Hamas, its policies do not directly address the specific social cleavages exacerbated by conflict and crises.

The membership of the PIJ overcomes existing cleavages. The movement's leadership is comprised of educated young men in their early thirties from low-to- middle class origins (Hatina, 2001: 27). In fact, one Islamic Jihad member said all the top elected leaders of the movement must have a doctorate (Marzouq, 2007). In addition to the dominant academic element, the leadership is comprised of former Fatah and Palestinian Liberation Army (PLA) activists (Hatina, 2001: 27). For example, some prominent figures at its inception included Jabr 'Ammar, a former officer in Palestine Liberation Forces (PLF) of the PLA; Ahmad Mahanna, former officer of PLF; Muhammad al-Jama'l, former PLF officer; and, Ramadan Shallah, former

\footnotetext{
${ }^{41}$ It is interesting to note that, in present day, PIJ has an excellent relationship with Fatah. After the Hamas-Fatah conflict in 2007, PIJ became even closer to Fatah than to Hamas.
} 
secularist and current leader of the movement (Rudolph and Van Engeland, 2008). Aside from its leadership, the PIJ members are also from the middle-to-lower socio-economic classes, ranging from rural to urban areas and spanning all generational cleavages (Marzouq, 2007). Male recruits under the age of eighteen and not mentally competent are not accepted. The PIJ, unlike Hamas, does not accept women activists.

In summary, the PIJ utilized the existing social cleavages that were exacerbated by conflict and crises to create a shared identity. While the paradigm does not posit the types of cleavages that activists utilize, the PIJ case suggests that ethnic, gender, generation, geographic, education, class-based, and ideological divisions provide a shared identity. Ideology was particularly important because the PIJ was able to create an ideological niche for itself by utilizing the failures of Palestinian nationalism and pan-Arabism and the passivity of the Brotherhood. Specifically, the PIJ provided a platform for political Islam. The common ideological framework provided by political Islam united the existing cleavages among the activists that mobilized to create the PIJ (Hatina, 2001).

Hamas Identity. The identity of Hamas is historically rooted in the Muslim Brotherhood in the West Bank and Gaza (Abu-Amr, 1994), which existed prior to the development of a Palestinian consciousness. The Muslim Brotherhood Society in Palestine emphasized Islamization from the bottom-up and renounced violence as a means for addressing the Palestinian question. Due to the apolitical nature of the Brotherhood, Israel allowed it to operate unfettered from 1967 and until its creation of Hamas in $1987 .^{42}$ During this long period, the Brotherhood created extensive networks throughout the West Bank and Gaza, providing needed

\footnotetext{
${ }^{42}$ Israel did not gain control over the territories until 1967. Prior to 1967, the Brotherhood in Gaza was under the control of Egypt and in the West Bank under that of Jordan. While it operated unfettered in Jordan, Egypt under Nasser would occasionally crackdown on the Brotherhood in Palestine because of the Egyptian Brotherhood's activities in Egypt-proper (Chehab, 2007).
} 
socio-welfare benefits to society. Consequently, the constituency and membership of the Brotherhood were comprised of the middle-to-lower socio-economic classes. Its membership and constituency overcame existing cleavages by including all segments of society, irrespective of age, education, ideology or gender. It was from the Brotherhood that Hamas was created.

Hamas' identity, therefore, is rooted in the Islamic reformist tradition of the Brotherhood, but it is a direct product of the 1987 Intifada (Mishal and Sela, 2006: 16). It strategically coopted the discourse of the Palestinian nationalist movements, which incorporated Islamic values and symbols, and presented itself as an ideological alternative, defined by Palestinian Islamic nationalism. It differentiated itself from the PIJ by emphasizing social development. This provided the movement with greater identification with society. It also does not just rhetorically address social cleavages, but attempts to provide programs to alleviate the conditions that create those divisions.

In summary, Hamas utilized the existing cleavages that were exacerbated by conflict and crises to create a shared identity. While the paradigm does not posit the types of cleavages that activists utilize, the Hamas case suggests that ethnic, gender, generation, geographic, education, class-based and ideological divisions provide a shared identity. In contrast to the PIJ, ideology was not particularly important for Hamas. Rather, it attempted to differentiate itself from the PIJ by providing policies and programs that overcame cleavages. Shared identities, according to the paradigm, produce mobilization to effect relations of domination.

Domination. The types present included political and military domination. The mobilizations of both the PIJ and Hamas were to affect social domination caused by the presence of the Israeli military and Israeli settlers living in the West Bank and Gaza. In contrast to Hamas, the PIJ's mobilization was also to affect relations of military domination. These types of 
subordination provided a link or shared sense of solidarity among the existing social identities in Palestinian society. The cases of the PIJ and Hamas confirm the paradigm's proposition that mobilization is to effect relations of domination.

Choice of Action. The paradigm posited that the relations of actors to the environment and their goals determine the possibilities and the limits of action. The movements of the PIJ and Hamas defined themselves as a resistance and not a political party at their creation. They both rejected Israeli military occupation and governance over the territories. Consequently, their goals were an end to political domination and establishment of Palestinian sovereignty.

Given the relations of the PIJ and Hamas to their environment and goals, the European paradigm would have predicted a different path for the PIJ than that of Hamas. The PIJ's mobilization was to affect domination caused by military occupation and the presence of Israeli settlers living inside the territories. Its goals were to affect Israeli occupation ideologically, politically, and militarily. Given the PIJ's relation to its environment and its goals, the paradigm suggests that violent protest would more likely than non-violent protest. In the case of Hamas, mobilization was to affect domination caused by military occupation, the presence of Israeli settlers, and economic exploitation. The goals of Hamas were to build institutions, charities, and committees; to strengthen the roots of resistance in both the West Bank and Gaza; to develop military capabilities; and, to develop dialogue with its Arab and Islamic neighbors. Given its goals and activists' relations to their environment, the European paradigm does help to explain Hamas’ adoption of non-violent protest at its mobilization.

In summary, the paradigm predicted that existing conflict exacerbated social cleavages to create a shared identity. The examination of the PIJ and Hamas demonstrated that conflict and crises exacerbated existing social cleavages to create a shared identity among activists. From 
these cleavages, the PIJ and Hamas were able to develop a shared identity among not only activists but also their constituency. These activists mobilized to create the PIJ and Hamas for affecting relations of political and military domination. The creation of a shared identity was thus necessary for the mobilization of the PIJ and Hamas.

\section{Conclusion}

This chapter sought to examine the mobilizations of the PIJ and Hamas from within the American and European paradigms. These paradigms are theoretical frameworks that exist within the social movement literature to explain movement mobilizations, each positing very different explanatory variables. The American paradigm posited that the existence of socioeconomic crises, deprivation and less structural differentiation in Palestinian society provided political opportunities for both PIJ and Hamas to use, which enabled their mobilizations. The European paradigm, on the other hand, posited that the existence of conflict and crises exacerbated social cleavages within Palestinian society and created shared identities among the activists within each of the movements, which enabled their mobilizations.

Given that both paradigms provided explanations for the mobilizations of the PIJ and Hamas, an argument can be made for the generality of the paradigms. An argument can also be made for an integrated approach. The PIJ and Hamas would not have been able to mobilize without shared identities among activists and those identities being rooted within existing social cleavages. Moreover, their mobilizations would not have been possible without the political opportunities provided by the existence of socio-economic crises, deprivations, and less structural differentiation. 


\section{Chapter 5}

\section{Mobilizing the MNLF, the MILF and the ASG}

This chapter seeks to examine the cases of the Moro National Liberation Front (MNLF), the Moro Islamic Liberation Front (MILF) and the Abu Sayyaf's Group (ASG). ${ }^{43}$ The MNLF mobilized in 1969; the MILF mobilized in 1977; and, finally, the ASG mobilized in 1991. At the time of their mobilizations, the MNLF engaged in non-violent resistance and the MILF and the ASG engaged in violent resistance (Banaloi, 2006; Anson, 2004; Bertrand, 1999; Roberts, 1995). The MNLF, similar to the PIJ and Hamas, adopted violent resistance after its initial mobilization (Roberts, 1995). The MNLF, the MILF and the ASG are rooted in and shaped by the history of Muslim separatism in the Southern Philippines. Understanding Muslim separatism is necessary to understand the mobilization of these movements.

\section{History of the Philippines and Muslim Separatism}

The Spanish colonized the Philippines in the $16^{\text {th }}$ century. In Spain's 300 years of occupation, the Muslim regions of Mindanao and Sulu were never colonized. Muslims were able to maintain their autonomy through armed resistance and governed themselves through three Muslim sultanates in Jolo, Sulu and Maguindanao (Buenida, 2005; Rinquet, 2002). The three sultanates correspond to the three largest ethno-linguistic groups present in the Muslim regions. While there are ten different ethno-linguistic cleavages, the largest three include the

\footnotetext{
${ }^{43}$ The MNLF, the MILF, and the ASG were selected for several reasons. First, the MNLF was the dominant resistance movement that emerged in 1971; the MILF in the latter part of the 1977; and, ASG in 1989, after MILF began negotiating with the government (Bertrand, 1999). It should be noted that the ASG was not a politically dominant resistance movement within the Muslim regions. Its popularity lies with the very poor, Muslim youth in Baislan and Sulu (Banaloi, 2006). Secondly, their mobilizations occurred at different times. Finally, the mobilization of these movements has not been examined from social movement theory.
} 
Maguindanaos, the Maranaos and the Tausugs (Dolan, 1981). In addition to ethno-linguistic cleavages, the Muslim regions were plagued by Islamic ideological differences. Consequently, the Muslim region prior to and after colonization has been tumultuous.

When the Americans arrived in 1898, Muslims for the most part maintained a neutral stance in the armed resistance campaign waged by Filipino nationalists (Dolan, 1991). An armed Filipino nationalist campaign actually began in the last part of the $19^{\text {th }}$ Century. Resistance to Spanish rule plagued the last quarter of the 19th Century in the Philippines. Filipino elites educated abroad and influenced by the French revolution, led Filipino nationalists under the Propaganda Movement (PM). The PM was not a secessionist movement. Rather, exiled Filipino liberals and university students waged cultural and literary resistance. They sought freedom of expression and equal representation and rights for all under Spanish governance. The Spanish violently repressed the non-violent movement, which sparked the armed campaign. When the armed resistance was finally able to defeat the Spanish, with the help of the Americans, they were prohibited from taking over the country. This sparked an all-out war between Filipinos against the Americans (Schirmer and Shalom, 1987).

During the war between the Filipino nationalists and the Americans, Muslims maintained a neutral stance. This neutral stance led to the signing of a Non-Interference Agreement in 1899 by Muslims and the Americans. In some of the Muslim regions, where Muslims had lost their territorial rights to the Spanish, armed resistance did occur. By 1903, a Muslim province under American military governance was established (Dolan, 1991). It was under American military administration that the most profound social, educational and governance changes occurred. The most significant social change was the outlawing of slavery. In the education arena, non-Muslim curricula replaced religious education. The legal system was overhauled, which replaced Islamic 
law with American law. Finally, the local governance structures implemented thwarted the authority of traditional Muslim leaders. These changes challenged the Islamic governance and social system that had been in place prior to Spanish colonization. Consequently, armed insurrections throughout the Muslim region broke out and lasted for thirteen years. By 1914, the Muslim region had been completely subjugated (Dolan, 1991).

Throughout the entire Philippines, the Americans had established a temporary colonial governance system with the intent of the country's eventual independence. This type of administration was implemented to placate the anti-imperialist at home and the Filipino nationalists. In so doing, the Americans incorporated the Philippine economic elite, wealthy landowners in particular, into the governance system. They also developed a program of free and universal education. This policy was particularly significant because it was something the Spanish never accomplished. Rather, the Spanish set up religious schools for the purpose of conversion. Finally, the Americans opened US markets to the wealthy landowners. Consequently, the colonial period brought wealth to the Filipino elite, but not to the masses. This was in large part because of the Filipino elite violently enforced the feudal agrarian system set up under the Spanish. Consequently, the masses continued to suffer from poor living conditions. The poor living conditions and lack of access to political institutions led to agrarian unrest, periodic peasant uprisings and massive labor strikes (Schirmer and Shalom, 1987: 37). The unrest of the 1920s and 1930s provided the impetus and mass support for armed struggle against the Americans. The reemergence of armed struggle and the worldwide economic crisis of 1929 led to the passage of the Tydings-McDuffe Act of 1934, which established 1946 as the date for Philippine independence (Buenida, 2005; Schirmer and Shalom, 1987). 
Before this could happen, the Japanese attacked the Americans on Philippine territory in 1941. By 1942, the Japanese obtained the support of the same Filipino elite that the Americans had and established a subservient but independent Philippine Republic in 1943. Despite the granting of independence, the Japanese conquest was opposed with violence. The Huks and Muslim resistance waged an armed campaign against the Japanese, with the aid of the Americans (Buenida, 2005; Dolan, 1991; Schirmer and Shalom, 1987). By 1944, coordinated resistance had removed the Japanese from Philippine soil. The Americans disarmed, arrested and dismantled the governments set up by the same resistance that had helped them defeat the Japanese (Schirmer and Shalom, 1987: 69). They reinstalled the same Filipino elite placed in power before the Japanese invaded. The very same elite collaborated with the Japanese in 1941.

Two years after the American reconquest of the Philippines, independence was granted. The Philippines went from colony to neocolony. That is, foreign domination was not removed despite the granting of independence (Buenida, 2005; Schirmer and Shalom, 1987). In addition to this, the Filipino elite had continued a policy of repression rather than inclusion of the peasant majority. That is, they maintained the feudal agrarian system put in place by the Spanish and continued by the Americans. At independence, the Filipino elites utilized the police and armed vigilantes to enforce violently the collection of past rents (Dolan, 1991). The peasants were unable to challenge the elites. The electoral candidates that promoted changes in peasant living conditions were prohibited from running for office and some assassinated (Kerkvliet, 1973). Consequently, the Huk-Rebellion broke out in 1949.

The Philippine government declared the Huk’s illegal, subversive, and sought aid from the American military to suppress the rebellion. With Huk defeat in the early 1950s, the domination of the Filipino elite over the masses continued unchallenged. The lower socio- 
economic classes were unable to challenge the elite despite the formally democratic governance system. The political system only provided the means for the elite factions to rotate in office. Meanwhile, the living conditions of the vast majority were miserable and getting worse, which finally erupted into non-violent protest in the latter part of 1971 and the beginning of 1972 (Frake, 1998). Again, with the aid of the Americans, this protest was violently repressed by the Philippine government despite its non-violent nature. The non-violent protest provided the Philippine government, led by Marcos, to justify the Declaration of Martial Law (Buenida, 2005). The Declaration of Martial Law sparked the Muslim Rebellion of 1972-1976 led by the Moro National Liberation Front (Frake, 1998).

Although Muslim separatism predates Spanish colonization, the conflict between Muslims and Filipinos has its origins in Spanish colonization. It is largely a product of the former's claim to independence and the preferential treatment given to the latter by the Spanish and Americans. The present day conflict between Muslims and Filipinos is “.... contestation of democratic space” (Buenida, 2005: 2). Muslims seek their right to self-determination and Filipinos seek affirmation of Philippine sovereignty over the territory. The problem with the Muslim separatist movement, in both the past and present, is its lack of a national consciousness that transcends the ethno-linguistic identities. Even opposition to Spanish rule failed to transcend these identities. Although still plagued by ethno-linguistic cleavages, Muslims were able to find some common ground under American colonization in the 1920s (McKenna, 2008). This common ground has helped the contemporary Muslim separatist movement.

In the 1920s, Muslim leaders began asserting their rights to independence through nonviolent protest. When the Americans denied their attempts, the separatist movement strategically adopted a Filipino identity to avoid losing power in the forthcoming independent Philippine state 
(McKenna, 2008). Even after independence and until the 1960s, the Muslim elites continued to define Muslim consciousness through participation in the Philippine Republic (Buenida, 2005). Consequently, this generation never challenged the legitimacy of the Philippine government. This lack of challenge led to their own loss of legitimacy among the younger, educated Muslim population.

The younger Muslim generation, composed of new educated intellectuals and professionals, revived the independence movement of the 1920s. The trigger event that sparked Muslim unrest was the Jabadiah massacre led by the Philippine military under Marcos' order (Buenida, 2005). The younger generation demanded the Muslim elite to seek redress for the incident. The Muslim elite remained silent, which sparked non-violent protest throughout the region (Frake, 1998). Muslim non-violent protests were joined by simultaneous protests held by the Filipino younger, educated generation (Bertrand, 1999). While the Muslims were protesting the injustice done to them by the Philippine government and the acquiescence of the Muslim elites, the Filipinos were protesting the growing centralization of power by the Philippine government and its use of violence (Buenida, 2005). In coordination with the Philippine military, the Christian armed resistance movement called the Illagas began engaging in acts of violence against the Muslim population. The Muslim students retaliated by forming their own armed bands called the Black Shirts. It is in these conditions that the Moro National Liberation Front mobilized.

The activists of the MNLF were the younger, educated Muslims that led the student protests against the Philippine government and the Muslim elite. These students sought to forge a national identity among the inhabitants of the Muslim region. While they were not successful in creating a national consciousness, the MNLF was successful in turning the derogatory Moro 
appellation into a positive connotation among Muslims in the Philippines. The positive connotation has resulted in the forging of a fragile but common identity among the inhabitants of the Muslim region, which has aided movements in their mobilizations.

In summary, the Muslim regions located in the Southern Philippines have been plagued with almost constant armed insurrections since Spanish and American colonization. The past Muslim separatist movements utilized crises, deprivation, conflict, structural differentiation and political opportunities to mobilize. All of these movements sought some form of autonomy or independence. Mobilization of past movements has shaped contemporary Muslim separatist movements. The contemporary Muslim separatist movements, as the next section addresses, are like their predecessors in that they too are calling for some form of autonomy or independence.

\section{Mobilization from the American Paradigm}

The conditions in the Philippines were relatively similar to those under Spanish and American colonization that aided activists in the mobilization of Muslim separatist movements. The period prior to and at the time of the MNLF mobilization was characterized by socioeconomic crises, deprivation, and a transition from greater to less structural differentiation. In the period prior to and at the time of the MILF mobilization was characterized by socioeconomic crises, deprivation, and a lack of structural differentiation. The time period prior to and at the time of the ASG mobilization was characterized by was characterized by socioeconomic crises, deprivation, and a transition from less to greater structural differentiation. According to the American paradigm, these variables do not cause mobilization. Rather, they provide political opportunities for activists to utilize. For the American paradigm, the role of the activists enables mobilization. This section examines the enabling explanatory variables and the way activists utilize them to explain the mobilizations of the MNLF, the MILF, and the ASG. 
Socio-Economic Crises, Deprivation and Structural Differentiation. Socio-economic crises were rampant in the Philippines throughout the 1950s and early part of the 1960s (Ando, 1969). The pace of industrialization faltered and manufacturing made little progress in increasing labor and capital resources, with little done to eliminate the mal-allocation of scarce resources (Williamson, 1969). The 1970s witnessed deterioration in trade, while the 1980s was plagued with rising interest rates (Blejer and Guerrero, 1990). Each crisis brought on drastic cuts in public expenditures and restrictive monetary policies. The majority of the inhabitants of the Philippines, and those in the Muslim regions, suffered from high levels of poverty, unemployment and under-employment. Those hardest hit were the poor and middle-class, both of whom were either unemployed or underemployed (Blejer and Guerrero, 1990; Kerkvliet, 1973). The Muslim regions had the "...least access to education, health, electricity, transport, water, and sanitation services-the basic infrastructure required to sustain any growth or development” (Gutierrez and Borras, 2004: 2). The following depicts the percent of GDP growth for the Philippines in comparison to Malaysia and Indonesia.

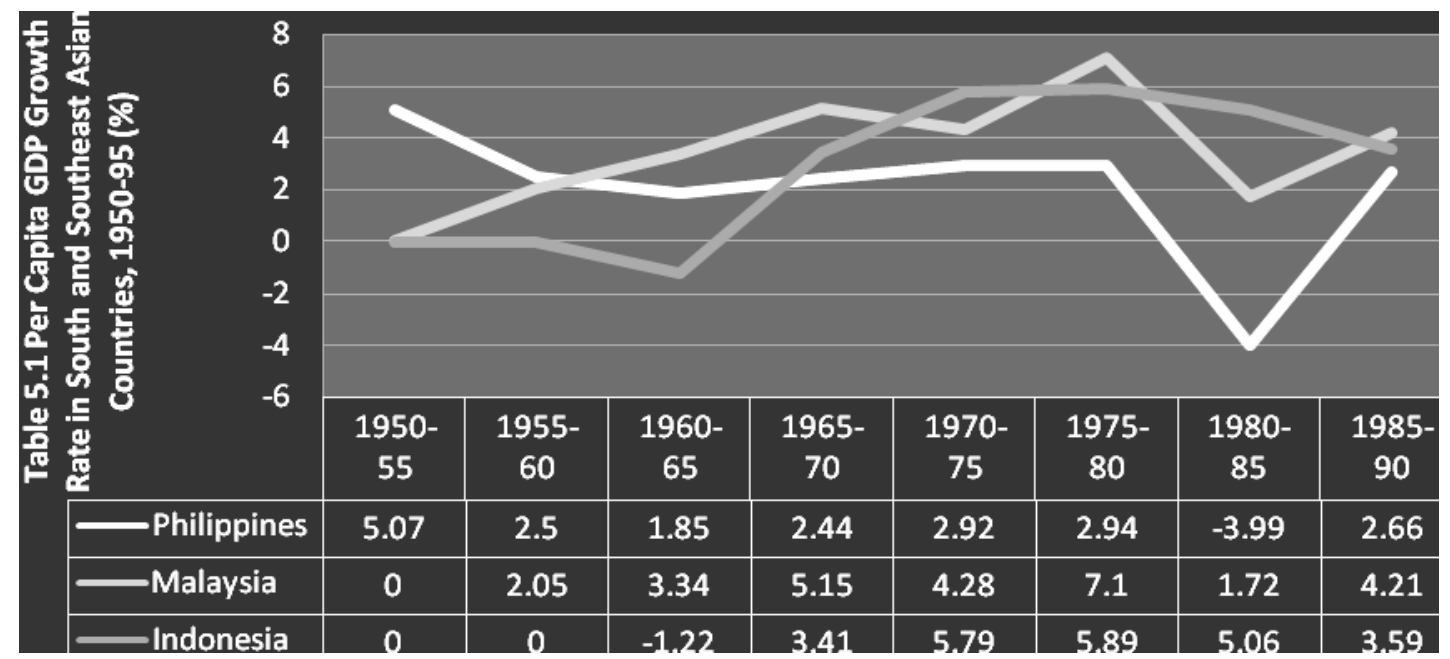

Source: Navaneentham (2002) 
The slow growth of GDP demonstrates the economic difficulties of the Philippines in comparison to the other countries in the region. These economic conditions had a profound effect on social relations (Ruland, 2003; Thompson, 1996; Blejer and Guerrero, 1990). Between 1945 and 1960 many areas, especially those closely connected to Manila, experienced significant social crises due to abrupt changes in social relations. Social relations, traditionally defined by kinship, familial, and factional relations, were replaced with individualism, instrumentalism, and politicization by the machine (Machado, 1974). These socio-economic crises produced deprivation.

Deprivation in the Philippines was exacerbated by government policies (Blejer and Guerrero 1990). State immigration policies that began under colonization and intensified after independence granted Muslim-owned land to Catholic settlers, which resulted in the latter becoming the majority in the Muslim regions. Consequently, land policies resulted in Muslims feeling pushed out of their ancestral home. Education policies gave preference to the Catholic dominated areas. The unequal and preferential treatment led to a rejectionist attitude among Muslims, which created real socio-economic inequalities.

Government policies resulted in psychological strain and political crises (Ruland 2003; Thompson 1996; Blejer and Guerrero, 1990; Magdalena, 1977; Kerkvliet, 1973). Psychologically, Muslims perceived their Filipino counterparts are being more mobile, economically well off, urban, and aspiring (Magdalena, 1977). Politically, there was a great disconnect between the people and politics, especially between the national political system and that of local administration (Blejer and Guerrero 1990; Kerkvliet 1973; Williamson 1969). The relationship between local and national politics was based on favoritism and pork barrel politics that resulted in the national economy being plunged into large deficits, especially during times of 
national election (Williamson 1969). Government official gave jobs and resources to their ethnic clans $^{44}$ and businesses owned by them, their families or friends (Ruland, 2003; Thompson, 1996; Blejer and Guerrero, 1990).

The political divide deepened in 1972 when Marcos implemented martial law, which lasted officially until 1981, but unofficially until 1988 when he was removed from office by the “People Power Movement” (Beunida, 2005). Even after Marcos was removed from power and Aquino replaced him in electoral victory, political turmoil continued to plague the Philippines economically and socially. From the 1960s to the 1990s, crises resulted in deprivation that led to widespread dissatisfaction with the existing status quo. In the Muslim regions, dissatisfaction extended to the Muslim elite due to their passivity. The younger, Muslim generation was unable to challenge the existing status quo due to lack of access to government institutions. Lack of access to government institutions was due to the nature of structural differentiation in the period of the 1960s to the 1990s.

According to the American paradigm, the level of structural differentiation is important because it determines whether activists have access to the government to redress the causes of deprivation. The level of structural differentiation differed when each of the movements mobilized. Prior to 1965, the governance structure was formally democratic, with universal suffrage and a two-party system. The two-party system consisted of the Partido Nationalista (NP) and the Liberal Party (LP), with political power vacillating between the two parties, but not without the use of violence, intimidation, corruption, and inter-and intra-factional rivalry (Thompson, 1996; Machado, 1974). Factionalism was largely a product of the two-party system being comprised of coalitions of provincial family factions. Power was derived from similar

\footnotetext{
${ }^{44}$ Members of society relied on and established networks with prominent families in order to receive socio-welfare and socio-economic benefits (Machado, 1974).
} 
provincial factions at the municipal level. Provincial factional elite derived their power from extended kinship, familial, patron-client, personal, and cultural-linguistic relations (Machado, 1974; Ando, 1969). Therefore, access to the governance structure depended on the connections individuals had to provincial elite; and, successful candidacy for political office depended on not only connections, but also the ability of candidates to provide tangible and intangible political and economic favors to the provincial elite (Ando, 1969).

Despite formal structural differentiation in the period prior to 1965, the activists that later formed the MNLF were excluded from the governance structure and the benefits derived from the patrimonial system due to their lack of connection with the provincial elite (Majul, 1999). Christian and Muslim elders dominated the provincial elite. The Muslim elite, cooperating with the central Philippine government, were equivalent to the Muslim Yes-men in Algeria under French colonization. Moreover, government policies intentionally excluded Muslims other than the Muslim elite from government positions and promoted underdevelopment in the Muslim dominated areas (Gutierrez and Borras, 2004).

From 1965, when Marcos came to power in the presidential election, to his declaration of martial law in 1972, there was a gradual centralization of political power at the national level. Marcos was able to justify an increase in national power by promising to implement a massbased public works program to improve the quality of life for all Filipinos (Dolan, 1991). Unfortunately, economic growth slowed, the quality of life deteriorated, and crime and violence spiraled out of control. Marcos responded with not only increased centralization but also violence. It was during this transition from greater to less structural differentiation that the MNLF mobilized. 
The increase in violence used by the government led to renewed armed insurrections by the New People’s Army. As a result, Marcos declared martial law in 1972. The Declaration of Martial Law ended the transition period and ushered in a new period characterized by a lack of structural differentiation. The period from 1972 to 1986 was characterized by authoritarianism and personal rule (Thompson, 1996; Macahdo, 1974). It was authoritative and personalistic because governance centered on the friends and family of Marcos, who personalized state institutions and extorted wealth from society. All non-governmental institutions were captured by the state, which was to say by Marcos friends and family. Similarly, all governmental institutions, ranging from the bureaucracy to the military, were headed by those loyal to and directly connected with Marcos (Thompson, 1996). Eventually, activities were curtailed with little outlet for dissent or participation. It was under these governance conditions that the MILF mobilized. The conditions when the MNLF mobilized permitted non-violent protest. In contrast, the conditions when the MILF mobilized did not permit non-violent protest. These same conditions characterized the period prior to the ASG mobilization. The period prior to and at the time of its mobilization was characterized by a transition from less to greater structural differentiation. The transition period begins with the removal of Marcos from power.

Marcos was removed from power in February 1986, according to Ruland (2003), by a peaceful display of "people’s power." Corazon Aquino, whose husband, a leading opposition figure who was assassinated by Marcos in 1983, came to power after supposedly losing the Marcos-rigged 1986 Presidential election (Ruland, 2003: 464). She came to power on the coattails of the "people’s power," but without a strong organization of her own. Taking power after decades of mismanagement by the Marcos family, the scope of the problems the new regime faced was enormous. And there were a series of division between the country's new 
rulers. The new era saw limited political, social and economic reform, constant attempts of military coups, and the occasional use of force during massive demonstrations. Aquino, according to Thompson (1996), was able to maintain power by acquiescing to the military's demands, reversing her stance on land reforms, halting investigations into human rights abuses by the military, and maintaining the socio-economic and political patronage system established under Marcos.

In conclusion, the transition from greater to less structural differentiation when the MNLF mobilized resulted in protests occurring outside conventional political boundaries. These protests did not occur through until crises caused widespread deprivation among all segments of the population. ${ }^{45}$ When protests erupted, Marcos responded with violence to suppress all segments of society (Majul, 1999; Dolan, 1991). There was no opposition to the use of government violence or policies implemented to redress grievances (Ruland, 2003; Thompson, 1996). After martial law was declared in 1972, all forms of non-violent protest ceased to exist due to the government's use of murder, disappearance and torture on all segments of the population (Political Terror Scale). Consequently, the form of protest after 1972 was violent.

Non-violent protests did not occur again until the mid 1980s (Ruland, 2003). From 1972 to the early 1980s, there was no opposition to the government's use of violence but policies were implemented redress grievances (Ruland, 2003; Thompson, 1996). For example, elites lobbied for the implementation of socio-economic and welfare policies in the Muslim region; and, Marcos granted concessions to Muslim and communist resistance movements (Ruland, 2003; Thompson, 1996; Machado, 1974; Ando, 1969). It was not until the mid-1980s that elite opposition began criticizing the government's use of repression (Dolan, 1991). These conditions

\footnotetext{
${ }^{45}$ Please see the discussion on Muslim separatism for more detail.
} 
characterized the MNLF, the MILF and the ASG mobilizations. The American paradigm posited that crises, deprivation, and structural differentiation do not cause mobilization. Instead, they are enabling factors that provide political opportunities for the activists to use for mobilization. The following sub-sections examine the movements' use of these opportunities separately.

The MNLF's Use of Political Opportunities. The activists that created the MNLF utilized political opportunities provided by the transition from greater to less structural differentiation, lack of access to and autonomous political institutions, socio-economic crises and deprivation. The creation of the MNLF, according to founding member Nur Misurari, was for the establishment of an independent state, the withdrawal of government troops in the Southern Philippines, a return of ancestral lands, greater autonomy, and the ability to implement Islamic law in Muslim dominated areas (Rudolph and Van Engeland, 2008; Bertrand, 1999). By calling for independence and greater autonomy in the Muslim region, the MNLF activists invoked the memory of the Muslim separatist movement of the 1920s (Dolan, 1991). The MNLF presented itself as representing the Muslim population, which enabled its activists to lead the Muslim masses in the non-violent protests of the late 1960s. The rise in prominence of the MNLF after its creation also enabled the activists to lead the region in the first Muslim rebellion since independence (Bertrand, 1999).

The MNLF thereby signified its rejection to the status quo, represented by the central Philippine government and the traditional Muslim elite in the Muslim region. The younger Muslim generation, fed up with economic inequality blamed the central Philippine government and the Muslim elites in the region for their collaboration (Frake, 1998). Rejection of the status quo resonated particularly with the younger, Muslim generation that were most affected by the unstable socio-economic conditions. While the MNLF did not seek Filipino acceptance and 
participation in its movement, it strategically utilized the existing conditions and anti-Marcos sentiment to attempt to forge a common identity among Muslims and Filipinos living in the Muslim regions. It also utilized external linkages created by the MNLF activists to promote socio-economic programs and to facilitate the provision of socio-welfare benefits to those in the region. The use of external linkages in this way signified the government's and the Muslim elite's inability to promote socio-economic development and their inadequate provision of resources to all living in the Muslim region. Consequently, the MNLF's anti-Marcos political program resonated with Muslims and Filipinos living in the Muslim region (Bertrand, 1999; Frake, 1998; Dolan, 1991).

In summary, the MNLF utilized political opportunities provided by the transition from greater to less structural differentiation, lack of access to and autonomous political institutions, socio-economic crises and deprivation. Consequently, the MNLF case confirms the American paradigm's proposition that movements utilized political opportunities to mobilize. It does not confirm the proposition that the political opportunities were utilized to create linkages between individuals, institutions and organizations. For the MNLF, the creation of linkages merely served as a political opportunity for activists to use crises and deprivation for mobilization.

The MILF's Use of Political Opportunities. The activists that created the MILF utilized political opportunities provided by lack of structural differentiation, lack of autonomous political institutions, and government use of repression. The creation of the MILF in 1977 was a response to the actions of the MNLF (Rudolph and Van Engeland, 2008; Bertrand, 1999; Frake, 1998). Consequently, the movement's mobilization has its roots in the MNLF and the historical, Muslim separatist movement. The MILF activists called for the creation of an independent state in the Muslim region. This call was a rejection of the MNLF signing of the 1976 Tripoli 
Agreement. By signing the Tripoli Agreement, the MNLF relinquished its call for independence and accepted autonomy in the Muslim region (Bertrand, 1999; Frake, 1998). The MILF rejected any form of autonomy as long as the Philippine government had central decision-making authority over the region and control of the purse strings (Rudolph and Van Engeland, 2008). The formation of the MILF thereby signified lack of structural differentiation and rejection of the status quo, represented by the Philippine government and the MNLF. It also rejected the MNLF's decision to halt armed resistance due to the Philippine government's continued use of repression in the Muslim region.

In summary, the MILF utilized political opportunities provided by lack of structural differentiation, lack of autonomous political institutions, and government use of repression. . Consequently, the MILF case confirms the American paradigm's proposition that movements utilized political opportunities to mobilize. It does not confirm the proposition that the political opportunities were utilized to create linkages between individuals, institutions and organizations. For the MILF, it utilized the linkages created by the MNLF for mobilization. In contrast to the MNLF's use of external linkages, the MILF did not use them at its inception to promote socioeconomic development programs or provision of resources to the region. Rather, it used the linkages to continue the armed resistance campaign initiated by the MNLF in the early 1970s.

The ASG's Use of Political Opportunities. The activists that created the ASG utilized political opportunities provided by lack of structural differentiation, lack of autonomous political institutions, and government use of repression. The creation of the ASG in 1991 was due to dissatisfaction among the younger, Muslim activists of the MNLF and the MILF (Banaloi, 2006; Montesano, 2003; Roberts, 1995). The ASG, thus, sought to bridge the gap between these movements with its creation. The younger, Muslim activists of the MNLF and the MILF were 
dissatisfied with their leaderships' failure to improve the conditions for the Muslim region. Consequently, the ASG has its roots in the historical, Muslim separatist movement. The ASG, according to founder Abdurajak Janjalani, called for the creation of an independent Islamic state and the implementation of Islamic law in the Muslim region and the continuation of armed resistance as long as the Philippine government continues to oppress the Muslim population (Rudolph and Van Engeland, 2008; Banaloi, 2006).

The formation of the ASG thereby signified lack of structural differentiation and rejection of the status quo, represented by the Philippine government, the MNLF and the MILF. It also rejected any attempts to halt armed resistance due to the Philippine government's continued use of repression in the Muslim region. In summary, the ASG utilized political opportunities provided by lack of structural differentiation, lack of autonomous political institutions, and government use of repression. The ASG case confirms the American paradigm's proposition that movements utilized political opportunities to mobilize. It does not confirm the proposition that the political opportunities were utilized to create linkages between individuals, institutions and organizations. For the ASG, it utilized the linkages created by the MNLF for mobilization. Similar to the MILF, the ASG did not use them at its inception to promote socio-economic development programs or provision of resources to the region. Rather, it used the linkages to continue the armed resistance campaign initiated by the MNLF in the early 1970s and continued by the MILF in the 1980s.

The MNLF's, the MILF's, and the ASG'S Choice of Action. According to the American paradigm, action occurring inside or outside conventional boundaries depends on greater or less openness/access (structural differentiation) and political opportunities (Meyer, 1999; Tarrow, 1992; Tilly, 1978; Eisenger, 1973). In the case of the MNLF and the ASG, transitional structural 
differentiation was underway. In the case of the MILF, there was a lack of structural differentiation. In all three, the movements utilized political opportunities to mobilize. Mobilization in all three movements occurred outside conventional political boundaries. The cases of the MNLF and the ASG demonstrate that transitional structural differentiation and political opportunities explain participation outside conventional political boundaries. The case of the MILF demonstrates that lack of structural differentiation and political opportunities explain participation outside political boundaries. All of these cases confirm the proposition posited by the American paradigm.

\section{Mobilization from the European Paradigm}

Throughout the history of the Muslim regions in the Southern Philippines, there have been conflicts that exacerbate existing social cleavages. The cleavages created a shared identity among the activists of the MNLF, the MILF and the ASG that mobilized to affect relations of domination. The mobilization of each movement was made possible by the creation of a shared identity among movement activists. For the European paradigm, it is the creation of a shared identity that produces the mobilization and not activists' use of political opportunities. Therefore, this section examines the role of identity in the MNLF's, the MILF's and the ASG's mobilization.

Conflict and Cleavages. The European paradigm posits that the presence of conflict exacerbates existing social cleavages. Armed conflict was present when the MNLF, the MILF and the ASG mobilized (Uppsala Conflict Database). Prior to the MNLF's mobilization in 1969, there was no conflict. Beginning in 1969, the Communist People's Party through its armed wing, the NPA, waged an armed campaign against the central government that lasted until 2006. In the Muslim regions, armed conflict between the MNLF and the central government occurred 
from 1972 to 1990. From the creation of the MILF in 1977 and until 1990, activists coordinated with the MNLF in its armed campaign. Similar to the MILF, the ASG has waged an armed campaign against the Philippine government since its inception. Since conflict was present prior to the mobilizations of the MILF and the ASG, the argument posited is that it alone cannot explain the exacerbation of existing social cleavages. Crises, as will be demonstrated, also contributed the salience of existing social cleavages. The salience of existing cleavages, according to the paradigm, provided a shared identity among activists.

Conflict (Frake, 1998; Brown, 1988) and socio-economic crises (Blejer and Guerrero, 1990) made salient ethnic, regional, urban-rural, educational, and economic or class-based cleavages. Ethnic cleavages exist between the Muslim and Filipinos living in Muslim regions and between the Muslim region and the majority Filipino regions (Frake, 1998; Brown, 1988). The ethnic cleavage was in part due to education and economic or income-based inequalities (Magdalena, 1977; Kerkvliet, 1973; Ando, 1969; Williamson, 1969). Regional, urban-rural and linguistic cleavages also exacerbated ethnic cleavages due to the on-going conflict and socioeconomic crises (Blejer and Guerrero, 1990). Within the urban-rural cleavages, there were classbased cleavages between the lower, middle and upper socio-economic classes. All of these cleavages were not only interrelated and have their roots in the long-standing conflict, but were also made salient by the existing political conditions. In particular, socio-economic crises, deprivation, lack of autonomy in existing political institutions, and inadequate provision of resources created divisions in the Philippines (Dolan, 1991).

In conclusion, conflict and crises exacerbated existing social cleavages among Muslims living in the Philippines. The European paradigm did not provide propositions regarding the type of cleavages made salient. The cases of the MNLF, the MILF and the ASG identified 
ethnic, regional, urban-rural, educational, and economic or class-based cleavages. According to the paradigm, these cleavages should have created a shared identity among the activists that mobilized to create each of the movements. The identity of each movement should overcome existing cleavages to promote unity.

The MNLF Identity. At its inception, the identity of the MNLF was defined by Islamic nationalism (Rudolph and Van Engeland, 2008; Bertrand, 1999; Frake, 1998). For the MNLF, the role of the state is to promote faith by providing institutions and resources to society. By defining its Muslim identity as such, the activists sought to transcend existing Islamic political ideological divisions. According to the Ira Lapidus (2002), the Muslim region in the Philippines is composed of Sufism, Salafiyyism and Islamic reformism (the Brotherhood tradition). Consequently, the MNLF was able to bridge the gap between the exiled Muslim elite and the younger, Muslim generation at its inception. It was not able to overcome the existing cleavage between the Muslim elite inside the Muslim region and the younger, Muslim generation. This is largely because activists sought to challenge their dominant roles in the existing socio-political order.

The MNLF also sought to overcome the existing ethnic cleavage present between Muslims and Filipinos living in the region. In particular, activists sought to forge a national identity transcending all existing cleavages within the Muslim region. Founder Nur Misurari stated "the correct name [of the inhabitants of the region] is Moro because [it] is our nationality...Christians can also be Moros. [T]here shall be no stressing the fact that one is a Tausugs, a Samal, a Yakan, a Subanon, a Kalagan, a Maguindanao, a Maranaos, or a Badjao, [one] is only a Moro" (Rudolph and Van Engeland, 2008: 153). In order to overcome these existing cleavages, the MNLF adopted an anti-Marcos political program (Bertrand, 1999; Frake, 
1998). It also sought to overcome existing cleavages by utilizing external linkages to establish socio-economic development programs and to facilitate the distribution of resources to the Muslim region. Finally, the MNLF was able to overcome educational cleavages through its membership and leadership. In summary, the MNLF attempted to create a shared identity that overcame some but not all the existing cleavages. The MNLF addressed economic or classbased, ethnic, educational, generational and ideological cleavages. It failed to address regional and urban-rural cleavages.

The MILF Identity. The identity of the MILF was defined by Islamic reformism, which promoted the restoration and development of civilization in the Muslim region (Rudolph and Van Engeland, 2008). For the MILF, the identity of the state is to be Islam, with its role being the promotion the faith by providing resources to religious institutions and the implementation of Islamic law. By defining its Muslim identity as such, the activists sought to go beyond the MNLF's attempt to transcend existing Islamic political ideological divisions by targeting the issues that concerned the traditional Muslim elite.

The MILF also sought to overcome the existing ethnic cleavage present between Muslims and Filipinos living in the region. The MNLF had sought to do this by attempting to create a national identity that could resonate among all living in the region, which the MILF rejected (Bertrand, 1999; Frake, 1998). Instead, activists sought to overcome the existing ethnic cleavage through membership. The MILF leadership was comprised mainly Maguindanao and Maranao activists, but its members were of multi-ethnic background (International Crisis Group, 2006). Through policies of coordination and cooperation, the MILF sought to overcome divisions along religious and secular orientations (Rudolph and Van Engeland, 2008). Generationally, it included the young and old. Similar to MNLF, however, the MILF had no political program 
outside of calling for an independent state in the Muslim region (Rudolph and Van Engeland, 2008). Despite its lack of programs, the MILF activists devoted themselves to securing diplomatic and material backing from outside the Muslim world for the promotion of socioeconomic development programs (International Crisis Group, 2006). In summary, the MILF attempted to create a shared identity that overcame some but not all the existing cleavages. While it addressed economic or class-based, ethnic, educational, generational and ideological cleavages, it failed to address regional and urban-rural cleavages.

The ASG Identity. The identity of the ASG incorporates both the Islamic nationalist and reformist traditions (Rudolph and Van Engeland, 2008). Through its political program, the ASG sought to bridge the gap between the MNLF and the MILF in particular. ${ }^{46}$ It differs from both the MNLF and the MILF in the sense that its leadership, not just its membership, incorporates educational, ethnic, linguistic and generational cleavages to promote unity (Banaloi, 2006; International Crisis Group, 2006). Similar to both the MNLF and the MILF, it failed to develop specific socio-economic and political programs to redress grievances in the Muslim regions (Rudolph and Van Engeland, 2008). In contrast to the other two movements, the ASG never utilized external linkages to promote development programs or the provision of resources to its constituency. It did use kidnapping-for-ransom tactics to acquire resources for its membership but not constituency (Rudolph and Van Engeland, 2008). Consequently, it was not able to overcome existing economic or class-based cleavages outside of its membership. In summary, the ASG attempted to create a shared identity that overcame some but not all the existing cleavages. It addressed ethnic, educational, generational and ideological cleavages, but failed to address economic or class-based, regional and urban-rural cleavages.

\footnotetext{
${ }^{46}$ See the discussion of the ASG in the section on the American paradigm for more details.
} 
Domination and Choice of Action. The ASG, the MNLF and the MILF all had shared identities that were created by some but not all of the existing cleavages that were exacerbated by conflict and crises. Shared identities, according to the paradigm, produce mobilization to affect relations of domination. The MNLF, the MILF and the ASG sought to affect political domination by calling for the creation of an independent state in the Muslim region at the time of their inception (International Crisis Group, 2006; Banaloi, 2006; Bertrand, 1999; Frake, 1998). The MILF and the ASG also sought to affect military domination by waging an armed resistance campaign at the time of their inception (International Crisis Group, 2006; Banaloi, 2006). These types of subordination provided a link or shared sense of solidarity among the existing social identities in the Muslim region. The cases of the MNLF, the MILF and the ASG confirm the paradigm's proposition that mobilization is to effect relations of domination.

The European paradigm posited that the relations of actors to the environment and their goals determine the possibiliteis and limits of action. All of the movements herein examined sought autonomy or the creation of an independent state in the Muslim regions. Given the subordinate status of Muslims to their Filipino counterparts and their inability to affect change within the conventional realm of politics, action occurred outside political boundaries. The MNLF engaged in non-violent resistance at its inception, whereas MILF and ASG both engaged in violent resistance. In summary, the paradigm predicted that existing conflict exacerbated social cleavages to create a shared identity. The examination of the MNLF, the MILF and the ASG demonstrated that conflict and crises exacerbated existing social cleavages to create a shared identity among activists. From these cleavages, the movements were able to develop a shared identity among not only activists but also their constituency. These activists mobilized to 
create the MNLF, the MILF, and the ASG for affecting relations of political and military domination. The creation of a shared identity was thus necessary for their mobilizations.

\section{Conclusion}

This chapter sought to examine the mobilizations of the MNLF, the MILF, and the ASG from within the American and European paradigms. These paradigms are theoretical frameworks that exist within the social movement literature to explain movement mobilizations, each positing very different explanatory variables. The American paradigm posited that the existence of socio-economic crises, deprivation and level of structural differentiation in Philippine society provided political opportunities for activists of the movements to use, which enabled their mobilizations. The European paradigm, on the other hand, posited that the existence of conflict and crises exacerbated social cleavages within the Muslim region in Philippine society and created shared identities among the activists within each of the movements, which enabled their mobilizations.

Given that both paradigms provided explanations for the mobilizations of the MNLF, the MILF and the ASG, an argument can be made for the generality of the paradigms. An argument can also be made for an integrated approach. These movements would not have been able to mobilize without shared identities among activists and those identities being rooted within existing social cleavages. Moreover, their mobilizations would not have been possible without the political opportunities provided by the existence of socio-economic crises, deprivations, and less structural differentiation. 


\section{Chapter 6 \\ General Conclusions: The Mobilization of Contemporary Islamic Resistance Movements}

Recent world events, ranging from international violence to elections, have propelled academics and policymakers to examine Islamic resistance movements more closely. Previous studies of such movements, in both the English and Arabic literature, has been limited to historical case studies. The lack of systematic cross-case comparisons has limited the development of generalizable propositions regarding movement mobilization. In a first effort to remedy this gap in the literature, this study examines the mobilization of Islamic resistance movements - the FIS, the PIJ, Hamas, the MNLF, the MILF and the ASG-in three different countries located in three different regions. Mobilization was examined utilizing the American and European paradigms within the social movement literature. The American paradigm emphasized the role of activists for mobilization, whereas the European paradigm emphasized identity. The central goal of the study is to answer the following: Do Islamic resistance movements share common mobilization characteristics?

\section{Mobilization of Islamic Resistance from the American Paradigm}

In the American paradigm, theorists posited that contemporary movements are a product of the political context. That is, political climate independent of movement mobilization affects the outcome of movements (Edelman, 2001; Goodwin and Jasper, 1999; Tarrow, 1998; Rochon, 1990). Movements, therefore, are symptoms of socio-economic crises (Edelman, 2001), deprivation and structural differentiation (Champagne 1983), which provide political opportunities (Goodwin and Jasper, 1999). Mobilization is made possible by movements, who 
are socially connected, using political opportunities to expand and gain a stake in the political and social system (Edelman, 2001; Cohen, 1985). They do so by relying on the linkages between individuals, organizations and institutions, which blurs the line between them and established political channels such as political parties (Rochon, 1990). The blurring of the line results in changes in the level of elite receptivity, changes in elite ability and willingness to repress movements, and the presence of elite allies (Edelman, 2001; Tarrow, 1998; Rochon, 1990). It also influences the type of protest, as both strategies and tactics are not chosen in a vacuum (Meyer 1999). Choice of action, then, depends on whether there is greater or less openness/access (structural differentiation) and political opportunities (repression, participation, and resources) available (Meyer, 1999; Tarrow, 1992; Tilly, 1978; Eisenger, 1973). The explanatory variables the American paradigm is concerned with included socio-economic crises, deprivation, structural differentiation, political opportunities, elite receptivity, and choice of action. The following table provides the findings across the cases, which is followed by a discussion. The table corresponds to the one presented in chapter two, which was used to guide data collection. Column one lists the variables of concern. Column two restates the focused, structured questions. The findings for each movement are then listed in the remaining columns. 


\begin{tabular}{|c|c|c|c|c|c|c|c|c|}
\hline Variables & Indicators/Questions & FIS & $P I J$ & Hamas & $M N L F$ & MILF & $A S G$ & $\begin{array}{l}\text { Percentage } \\
\text { of Cases }\end{array}$ \\
\hline $\begin{array}{l}\text { Socio-Economic } \\
\text { Crises }\end{array}$ & $\begin{array}{l}\text { Were socio-economic crises } \\
\text { present? If so, did they lead to } \\
\text { deprivation? }\end{array}$ & Yes & Yes & Yes & Yes & Yes & Yes & $100 \%$ \\
\hline Deprivation & Was deprivation present? & Yes & Yes & Yes & Yes & Yes & Yes & $100 \%$ \\
\hline \multirow[t]{5}{*}{$\begin{array}{l}\text { Structural } \\
\text { Differentiation }\end{array}$} & $\begin{array}{l}\text { Was there greater structural } \\
\text { differentiation? }\end{array}$ & No & No & No & No & No & No & $100 \%$ \\
\hline & $\begin{array}{l}\text { Was there less structural } \\
\text { differentiation? }\end{array}$ & No & Yes & Yes & No & Yes & Yes & $50 \%$ \\
\hline & $\begin{array}{l}\text { Was there transitional structural } \\
\text { differentiation? }\end{array}$ & Yes & No & No & Yes & No & Yes & $50 \%$ \\
\hline & $\begin{array}{l}\text { Was political participation } \\
\text { prohibited? }\end{array}$ & No & Yes & Yes & No & Yes & No & $50 \%$ \\
\hline & $\begin{array}{l}\text { Was there access to government } \\
\text { for redressing grievances? }\end{array}$ & Yes & No & No & Yes & No & Yes & $50 \%$ \\
\hline \multicolumn{9}{|l|}{$\begin{array}{l}\text { Political } \\
\text { Opportunities }\end{array}$} \\
\hline Crises/Deprivation & $\begin{array}{l}\text { Did movements utilize these for } \\
\text { mobilization? }\end{array}$ & Yes & Yes & Yes & Yes & No & No & $67 \%$ \\
\hline $\begin{array}{l}\text { Structural } \\
\text { Differentiation }\end{array}$ & $\begin{array}{l}\text { Did movement use the level of } \\
\text { structural differentiation for } \\
\text { mobilization? }\end{array}$ & Yes & Yes & Yes & Yes & Yes & Yes & $100 \%$ \\
\hline Repression & $\begin{array}{l}\text { Did movements use for } \\
\text { mobilization? }\end{array}$ & No & Yes & No & No & Yes & Yes & $50 \%$ \\
\hline \multirow[t]{2}{*}{$\begin{array}{l}\text { Government } \\
\text { Provision of } \\
\text { Resource }\end{array}$} & $\begin{array}{l}\text { Did the governing authority } \\
\text { provide subsistence resources to } \\
\text { society? }\end{array}$ & Yes & Yes & Yes & Yes & Yes & Yes & $100 \%$ \\
\hline & $\begin{array}{l}\text { Did movements use inadequate } \\
\text { government provision of } \\
\text { resources? }\end{array}$ & Yes & Yes & Yes & Yes & No & No & $67 \%$ \\
\hline \multirow[t]{2}{*}{ Access to Resources } & $\begin{array}{l}\text { Did society have access to those } \\
\text { resources? }\end{array}$ & Yes & Yes & Yes & Yes & Yes & Yes & $100 \%$ \\
\hline & $\begin{array}{l}\text { Did movements use this for } \\
\text { mobilization? }\end{array}$ & Yes & Yes & Yes & Yes & No & No & $67 \%$ \\
\hline \multirow[t]{2}{*}{$\begin{array}{l}\text { Autonomous Political } \\
\text { Institutions }\end{array}$} & $\begin{array}{l}\text { Were the political institutions } \\
\text { free from government } \\
\text { manipulation? }\end{array}$ & No & No & No & No & No & No & $100 \%$ \\
\hline & $\begin{array}{l}\text { Did movements utilize this for } \\
\text { mobilization? }\end{array}$ & Yes & Yes & Yes & Yes & Yes & Yes & $100 \%$ \\
\hline \multirow[t]{2}{*}{$\begin{array}{l}\text { Access to Political } \\
\text { Institutions }\end{array}$} & $\begin{array}{l}\text { Did society have access to } \\
\text { political institutions? }\end{array}$ & Yes & No & No & No & No & No & $83 \%$ \\
\hline & $\begin{array}{l}\text { Did movements utilize this for } \\
\text { mobilization? }\end{array}$ & Yes & Yes & Yes & Yes & Yes & Yes & $100 \%$ \\
\hline \multirow[t]{4}{*}{ Elite Receptivity } & $\begin{array}{l}\text { Were there changes in elite } \\
\text { receptivity to the use of } \\
\text { repression? }\end{array}$ & No & No & No & No & No & Yes & $83 \%$ \\
\hline & $\begin{array}{l}\text { Did movements use this for } \\
\text { mobilization? }\end{array}$ & No & Yes & Yes & No & No & No & $33 \%$ \\
\hline & $\begin{array}{l}\text { Were there attempts by elites to } \\
\text { ally societal grievances? }\end{array}$ & Yes & No & No & No & Yes & Yes & $50 \%$ \\
\hline & $\begin{array}{l}\text { Did movements utilize this for } \\
\text { mobilization? }\end{array}$ & Yes & No & No & No & Yes & Yes & $50 \%$ \\
\hline
\end{tabular}


According to the paradigm, crises, deprivation and level of structural differentiation do not cause mobilization. Rather, they provide political opportunities for activists to use for mobilization. Socio-economic crises were present when all six movements mobilized, despite temporal differentiation. The causes for such crises differed, however. When the FIS mobilized in Algeria, the crisis was a product of declining oil revenues, failed economic policies, and a cut in state socio-welfare benefits. When the PIJ and Hamas mobilized in Palestine, the crisis was a product of the ongoing Palestinian-Israeli conflict. When the MNLF and the MILF mobilized, the crisis was a product of misallocation of resources, a decline in trade and industrialization, and a cut in socio-welfare benefits. When the ASG mobilized, the crisis was a product of government corruption, rising interest rates, high levels of poverty, unemployment and underemployment, and severe cuts in public expenditures. These socio-economic crises led to deprivation in the societies in which all of the movements mobilized.

Socio-economic crises and deprivation were exacerbated by the level of structural differentiation. According to the paradigm, structural differentiation is important because it determines whether activists have access to the government to redress the causes of deprivation. In the cases examined, less structural differentiation characterized the political environment in which three of the movements' mobilized. In particular, lack of structural differentiation was present when the PIJ, Hamas, and the MILF mobilized. In the other three cases, there were transitions underway. In the cases of the FIS and the ASG, the transitions taking place were from less-to-greater structural differentiation; and, in the case of the MNLF, the transition from greater structural differentiation to less structural differentiation was underway.

In the cases where there was a lack of structural differentiation, all members of society were prohibited from political participation and accessing the government to redress grievances. 
In contrast, political participation and access to the government to redress grievances were limited in the cases where transitional structural differentiation was underway. In all the cases, the ability for members of society to redress grievances was confounded by lack of autonomous political institutions and government use of repression. With the exception of the period when the ASG mobilized, the political elites in each of the countries did not oppose the use of repression. Attempt to mediate grievances was made by the governing authority in each case to provide members of society with resources for subsistence living. These conditions provided political opportunities for the activists of each Islamic resistance movement to utilize for mobilization.

The political opportunities utilized by activists from all the Islamic resistance movements included the level of structural differentiation and access to and lack of autonomous political institutions. Activists of the Islamic resistance movements used these opportunities to create linkages between individuals, institutions and organizations, which was necessary for their mobilizations. The creation of linkages did not blur the line between them and conventional political parties or produce changes in elite receptivity. Finally, use of crises and deprivation, access to and inadequate government provision of resources, elite receptivity and government use of repression were not important for the activists of Islamic resistance movements. Political opportunities were also important for the type of action adopted by activists.

For the American paradigm, political opportunities and structural differentiation define the choice of action. For Islamic resistance movements, a lack of and transitional structural differentiation and use of the opportunities provided by lack of access to autonomous political institutions explained participation outside conventional political boundaries. Crises, deprivation, and access to and lack of inadequate government provision of resources were also 
important for the activists of the FIS, the PIJ, Hamas and the MNLF, who adopted non-violent protest at the time of their mobilization. These opportunities were different from the movements that engaged in violent protest. The activists of the MILF and the ASG adopted violent protest at the time of their mobilization. The opportunities that these two movements had in common, which differed from the others, were widespread government use of repression and lack of access to and lack of government provision of resources.

The findings across the violent and non-violent cases permit the articulation of several propositions regarding Islamic resistance movements. First, access to and government provision of resources decrease the severity of collective action, making non-violent protest more likely. Conversely, lack of access to and inadequate government provision of resources increase the severity of collective action, making violent protest more likely. Third, a movement's use of political opportunities provided by socio-economic crises, deprivation, and lack of activists' access to political institutions indicates that the type collective action to be taken initially would be non-violent protest. Fourth, a movement's lack of use of political opportunities provided by socio-economic crises, deprivation, and lack of activists' access to political institutions indicates that the type collective action to be taken initially would be violent protest. Fifth, the absence of widespread government use of repression decreases the severity of collective action, making non-violent protest more likely. Finally, widespread government use of repression increases the severity of collective action, making violent protest more likely.

In conclusion, the examination of Islamic resistance movements identified common mobilization characteristics that also confirmed the propositions posited by the American paradigm. First, the cases confirmed that movement activists utilize political opportunities. Second, the proposition that political opportunities create linkages between individuals, 
institutions, and organization was confirmed. Third, the cases reified the importance of linkages to mobilization. They, however, could not confirm the proposition that linkages blur the line between movements and conventional political parties. The proposition of linkages and the blurring of the line producing change in elite receptivity also cannot be confirmed. Lack of confirmation of these propositions may be due to the nature of the cases examined in this study. Finally, in the case of Islamic resistance movements, the proposition that the level of structural differentiation and political opportunities lead to action outside political boundaries can be confirmed but through specification that, a lack of or transitional structural differentiation, coupled with the lack of access to autonomous political institutions, leads to action outside political boundaries.

\section{Mobilization from the European Paradigm}

The American failed to consider the role identities play in mobilization. Theorists within the European paradigm posited that contemporary movements were mirrors of conflicts found in society (Rochon, 1990). This is because conflict creates new-shared identities based on existing social cleavages (Touraine, 1988). Identities produce collective action or mobilization (Vahabzadeh, 2001) to effect relations of social domination (Edelman, 2001). The process of mobilization, according to the European paradigm, is determined by the relation of actors to the ends of their action, which provides the possibilities and limits of their action; and, by the relationship of actors to their environment, which identifies the field in which action takes place. The variables that this paradigm is concerned with include conflict, social cleavages, identity, and social domination. The following table provides the findings across the cases, which is followed by a discussion. 


\begin{tabular}{|c|c|c|c|c|c|c|c|c|}
\hline Variables & Indicators/Questions & FIS & $P I J$ & Hamas & MNLF & MILF & $A S G$ & $\begin{array}{l}\text { Percentage } \\
\text { of Cases }\end{array}$ \\
\hline \multirow[t]{2}{*}{ Conflict } & $\begin{array}{l}\text { Was conflict present at } \\
\text { the time in which each } \\
\text { movement mobilized? }\end{array}$ & No & Yes & Yes & Yes & Yes & Yes & $83 \%$ \\
\hline & $\begin{array}{l}\text { Did conflict exacerbate } \\
\text { existing cleavages? }\end{array}$ & No & Yes & Yes & Yes & Yes & Yes & $83 \%$ \\
\hline \multirow[t]{2}{*}{ Crises } & Were crises present? & Yes & Yes & Yes & Yes & Yes & Yes & $100 \%$ \\
\hline & $\begin{array}{l}\text { Did crises exacerbate } \\
\text { existing cleavages? }\end{array}$ & Yes & Yes & Yes & Yes & Yes & Yes & $100 \%$ \\
\hline \multirow[t]{2}{*}{$\begin{array}{l}\text { Social } \\
\text { Cleavages }\end{array}$} & $\begin{array}{l}\text { What existing social } \\
\text { cleavages were present } \\
\text { when the movements } \\
\text { mobilized? }\end{array}$ & \begin{tabular}{|l} 
Economic-Class \\
Based/ Ethno- \\
Religious/ \\
Gender/ \\
Geographical/ \\
Generational
\end{tabular} & \multicolumn{2}{|c|}{$\begin{array}{c}\text { Economic-Class Based/ } \\
\text { Educational/ Ethno-Religious/ } \\
\text { Geographical/ Generational/ } \\
\text { Ideological }\end{array}$} & \multicolumn{3}{|c|}{$\begin{array}{l}\text { Ethno-Religious/ Economic-Class Based/ } \\
\text { Educational/ Geographical }\end{array}$} & \\
\hline & $\begin{array}{l}\text { What led to the salience } \\
\text { of those cleavages? }\end{array}$ & \begin{tabular}{|l|} 
Crises \\
\end{tabular} & Conflict/Crises & Conflict/Crises & Conflict/Crises & Conflict/Crises & Conflict/Crises & \\
\hline \multirow[t]{3}{*}{ Identity } & $\begin{array}{l}\text { Did each of the } \\
\text { movements have a } \\
\text { shared identity? }\end{array}$ & Yes & Yes & Yes & Yes & Yes & Yes & $100 \%$ \\
\hline & $\begin{array}{l}\text { Did their shared identity } \\
\text { overcome all existing } \\
\text { social cleavages? }\end{array}$ & Yes & Yes & Yes & No & No & No & $50 \%$ \\
\hline & $\begin{array}{l}\text { If not all, which types } \\
\text { of cleavages did it } \\
\text { overcome? }\end{array}$ & All & \multicolumn{2}{|c|}{$\begin{array}{l}\text { All/ Movements also addressed } \\
\text { gender. }\end{array}$} & $\begin{array}{l}\text { Economic- } \\
\text { Class-based/ } \\
\text { Educational/ } \\
\text { Ethno- } \\
\text { Religious/ } \\
\text { Generational/ } \\
\text { Ideological }\end{array}$ & $\begin{array}{l}\text { Economic- } \\
\text { Class Based/ } \\
\text { Educational/ } \\
\text { Generational/ } \\
\text { Ideological }\end{array}$ & $\begin{array}{l}\text { Educational/ } \\
\text { Ethno- } \\
\text { religious// } \\
\text { Generational/ } \\
\text { Ideological }\end{array}$ & \\
\hline \multirow[t]{2}{*}{$\begin{array}{c}\text { Social } \\
\text { Domination }\end{array}$} & $\begin{array}{l}\text { Did the movements } \\
\text { mobilize for effecting } \\
\text { relations of } \\
\text { domination? }\end{array}$ & Yes & Yes & Yes & Yes & Yes & Yes & $100 \%$ \\
\hline & $\begin{array}{l}\text { What type of } \\
\text { domination? }\end{array}$ & \begin{tabular}{|l|} 
Bureaucratic/ \\
Political/ \\
Military \\
\end{tabular} & $\begin{array}{l}\text { Political/ } \\
\text { Military }\end{array}$ & \multicolumn{2}{|c|}{ Political } & \multicolumn{2}{|c|}{ Political/ Military } & \\
\hline
\end{tabular}


According to the European paradigm, conflict exacerbates existing cleavages within society. With the exception of Algeria, conflict in part exacerbated existing cleavages within the societies where Islamic resistance movements mobilized. In Algeria, existing cleavages were made salient by socio-economic crisis. Socio-economic crises also exacerbated existing cleavages in Palestine and the Philippines. Economic-class based, educational, ethno-religious and geographical cleavages were common in Algerian, Palestinian and Philippine societies. Based on these findings, it is posited that conflict or socio-economic crises exacerbated the existing cleavages in the societies where Islamic resistance movements mobilized.

Cleavages are important for mobilization because they create a shared identity among movement activists, according to the paradigm. A shared identity existed among the activists that mobilized to form the FIS, the PIJ, Hamas, the MNLF, the MILF and the ASG. In only the cases of the FIS, the PIJ and Hamas were identities shaped by all of the existing societal cleavages. In the other three cases, only some of the existing cleavage formed part of the activists' identity.

An even more interesting finding was that some of the existing cleavages were not salient prior to movement mobilization. The most significant difference was that of ideology, which was only directly related to socio-economic crises and conflict in the Palestinian cases. Yet, in all of the movements, ideology helped to provide a shared identity among activists. The role of ideology was a significant due to the formation of the movements being in part based on the rejection of the status quo.

The European paradigm does not address the role of the status quo, but the American paradigm does. Similarly, the American paradigm does not address the role of identity and 
ideology in particular. As these cases demonstrate, ideology is important for creating shared identities, which is indirectly affected by conflict and crises. Movement activists also use it as a tool. In particular, the activists in all of the cases were able to provide a shared identity through ideological differentiation from the existing status quo. This thereby created ideological cleavages within society that were not salient prior to mobilization. Relatedly, all Islamic resistance movements activists in this study were able to create a shared identity through interaction with one another and society-at-large.

According to the European paradigm, shared identities produce mobilization to effect relations of social domination. In all of the cases, mobilization of movement activists was to affect relations of domination caused by political subordination. In three of the cases, it was not just to effect domination caused by political subordination but also military subordination. To affect relations of domination all the movements mobilized outside conventional political boundaries. The relation of actors to their environment and goals makes action occurring outside political boundaries possible, according to the paradigm. At the time of their mobilizations, the PIJ, Hamas, the MNLF, the MILF and the ASG defined themselves as resistance to the existing status quo. These movements also had similar goals, namely the creation of an independent state or autonomous region from the existing governing authority and an end to domination. Hamas was different from the other four in the sense that it also included socio-economic development of Palestinian society as one of its goals.

The FIS was also different from the others. First, the FIS did not define itself as a resistance movement. Rather, it defined itself an opposition party. The difference in the definition of self is related to goals. The FIS did not reject the Algerian state; it was not calling for the overthrow of the governance system or governing party. Instead, it was calling for 
freedom of expression and the right to the formation of political parties for participating in the existing governance structure. The FIS' overarching goals were restoration of Algerian sovereignty and, similar to the other movements, an end to political domination.

In summary, the examination of Islamic resistance movements identified some common mobilization characteristics that also confirmed the propositions posited by the European paradigm. First, the proposition that conflict and/or crises exacerbate(s) existing cleavages, which provides a shared identity among movement activists was confirmed. Second, it was confirmed that mobilization is to effect relations of domination. Finally, the proposition that the relation of these actors to their environment and goals can explain participation outside conventional political boundaries was confirmed.

\section{Conclusion}

Movement mobilization is a widely studied phenomenon, but has been largely limited to cases arising in the United States, Europe, South Africa and Latin America. Therefore, this study sought to examine the mobilizations of six contemporary Islamic resistance movements, namely the Islamic Salvation Front, the Islamic Jihad Movement, the Hamas, the Moro National Liberation Front, the Moro Islamic Liberation Front and Abu Sayyaf's Group. Each mobilization was examined through the American and European paradigms.

From the American paradigm, activists utilizing political opportunities explained the mobilization of Islamic resistance movements. In contrast, the European paradigm explained their mobilization through the creation of a shared identity. The mobilization of Islamic resistance movements demonstrated that both the paradigms are correct in their assumptions. Mobilization would not have been possible without a shared identity among movement activists. The identity of these activists was created in part by the role of socio-economic crises and 
conflict. Socio-economic crises caused actual and perceived deprivation among members of the societies where the activists resided. Consequently, the existing societal cleavages were exacerbated by crises and conflict. The salient cleavages were directly and in some instance indirectly related to conflict and socio-economic crises. Socio-economic crises and deprivation were also confounded by the level of structural differentiation. This is because the level of structural differentiation determined whether society and thereby activists could access government to redress grievances. Islamic resistance activists utilized political opportunities provided by the level of structural differentiation and lack of autonomous political institutions to aid in their mobilization. In addition to the level of structural differentiation and lack of autonomous political institutions to aid in their mobilization, activists also used the government's inadequate provision of resources to create linkages between individuals, institutions and organizations. Linkages were necessary for the mobilization of Islamic resistance movements, but they did not blur the line between the movements and conventional political or produce changes in elite receptivity. Instead, linkages helped to create a shared identity between movement activists and society-at-large. The creation of a shared identity between activists and society was necessary for producing mobilization to affect relations of social domination. The relation of activists to their goals and environment determined the mobilization of Islamic resistance movements outside conventional political boundaries. The environment was defined by the lack of, or transitional, structural differentiation and the lack of access to autonomous political institutions.

In conclusion, the Islamic resistance movements herein examined shared common mobilization characteristics. These characteristics were common with those found in other studies within the social movement literature on movement mobilizations. Consequently, 
general propositions posited by the American and European paradigms were confirmed for the most part and were further specified in others to provide greater explanatory power. Given that both paradigms provided explanations for these movements' mobilizations, an argument can be made for the generality of the paradigms. An argument can also be made for an integrated approach. None of the movements would have been able to mobilize without shared identities among their activists and those identities being rooted within existing social cleavages. Moreover, their mobilization would not have been possible without the political opportunities that were provided by the existence of socio-economic crises, deprivations, and less structural differentiation. This study, therefore, reiterates existing calls for an approach that seeks to integrate both the American and European paradigms. 


\section{Bibliography}

Abu-Amr, Ziad. Islamic Fundamentalism in the West Bank and Gaza. Indiana: Indiana University Press, 1994.

Abulhadi, Rabab. "The Palestinian Women’s Autonomous Movement: Emergence, Dynamics, and Challenges.” Gender \& Society, 1998.

Abu-Nimr, Mohammed. "A Framework for Nonviolence and Peacebuilding in Islam." Journal of Law and Religion, 2000-2001: 217-265.

Addi, Lahouari. L'Algerie et la democratic: pouvoir et crise du politique dans I'Algerie contemporaine. Paris, Editions la Decouverte, 1994.

Al-Baraghouti, Iyad. Al-Aslama wal-Siyasa fi al-Aradi al-Filastiniiyya al-Muhtalla. Jerusalem: Markaz al-Zahra lil-Dirasat wal-Abhath, 1990.

Alexander, Christopher. "The Architecture of Militancy: Workers and the State in Algeria, 19701990." Comparative Politics, 2002: 315-335.

Al-Hamad, Jawad and Iyad al-Barghouti, eds. Dirasa fi al-Fikr al-Siyasi li-Harakat alMuqawma al-Islamiyya (Hamas), 1987-1996. Amman: Markaz Dirsat al-Shar al-Awsat, 1997.

Al-Jazeera. "Al-Jazeera interview with Nafidh Azzam." Financial Times, January 24, 2004.

Ando, Hirofumi. "A Study of Voting Patterns in the Philippine Presidential and Senatorial Elections, 1946-1965." Midwest Journal of Political Science, 1969: 567-586.

Ando, Hirofumi. "A Study of Voting Patterns in the Philippine Presidential and Senatorial Elections.” Midwest Journal of Political Science, 1969: 567-586.

Appadurai, Arjun. "Grassroots Globalization and the Research Imagination.” Public Culture, 2000: 1-19.

Awwad, Elia. "Broken Lives: Loss and Trauma in Paletinian-Israeli Relations." International Journal of Politics, Culture and Society, 2004: 405-414

Azzam, Abdallah. Al-Difa' 'An aradi al-Muslimin Ahamm Furud al-Ayan. Jidda: Dar alMujtama, 1987.

Azzam, Nafidh. "Islamic Jihad Movement urges Palestinians to Register for Elections." Financial Times, September 24, 2004.

Banaloi, R.C. “The Abu Sayyaf Group: From Mere Banditry to Genuine Terrorism.” Southeast Asian Affairs, 2006.

Banlaoi, Rommel C. "The Abu Sayyaf's Group: From Mere Banditry to Genuine Terrorism." Southeast Asian Affiars, 2006.

Baumgartner, H. "The Three Faces/Phases of Palestinian Nationalism." Journal of Palestine Studies, 2005: 25-48.

Bertrand, Jacques. "Peace and Conflict in the Southern Philippines: Why the 1996 Peace Agreement is Fragile." Pacific Affiars, 1999: 37-54.

Bin Yusef, Ahmad. Harkat al-Muqawama al-Islamiyya Hamas, KHalifat al-Nash'a wa-Aqfaq al-Masir. Woth, Ill: al-Markaz al-'Alami lil-Buhuth wal-Dirasat, 1989.

Blejer, Mario I. and Isabel Guerrero. "The Impact of Macroeconomic Policies on Income Distribution: An Empirical Study of the Philippines.” The Review of Economics and Statistics, 1990: 414-423.

Bodansky, Yossef. Chechen Jihad: Al Qaeda's Training Ground and the Next Wave of Terror. New York: HarperCollins Publishers, 2007. 
Brett, Michael. "Anglo-Saxon Attitudes: The Algerian War of Independence in Retropsect." The Journal of African History, 1994: 217-235.

Brown, David. "From Peripheral Communities to Ethnic Nations: Separatism in Southeast Asia.” Pacific Affairs, 1988: 51-77.

Buenida, Rizal G. “The State-Moro Armed Conflict in the Philippines: Unresolved National Question or Question of Governance.” De La Salle University-Manila, 2005.

Burke, Edmund III. "Theorizing the Histories of Colonialism and Nationalism in the Maghrib." Arab Studies Quarterly, 1998.

Carroll, W. K. \& Hackett, R. A. "Democratic media activism through the lens of social movement theory.” Media, Culture \& Society, 2006: 83-104.

Celik, Zeynep. “Colonialism, Orientalism and the Canon.” The Art Bulletin, 1996.

Champagne, Duane. "Social Structure, Revitalization Movements and State-building: Social Change in Four Native American Societies." American Sociological View, 1983: 754763.

Chhibber, P.K. "State Policy, Rent Seeking and the Electoral Sucess of a Religious Party in Algeria." The Journal of Politics, 1996: 126-148.

Choe, Yonhyok. "Social Cleavage and Party Support: A Comparison of Japan, South Korea, and the United Kingdom." University College, Research Reports 5. 2002. www.divaportal.org/diva/getDocument?urn_nbn_se_sh_diva-41-1_fulltext.pdf (accessed May 14, 2008).

Cohen JL. "Strategy or identity: new theoretical paradigms and contemporary social movements.” Social Research, 1985: 663- 716.

Crisis Group. "Southern Philippines Backgrounder: Terrorism and the Peace Process. International Crisis Group, 2004: 1-43.

Crisis Group. "Philippines Terrorism: The Role of Militant Islamic Converts.” International Crises Group, 2005: 1-35.

Della-Porta, D. and M. Diani. Social Movements: An Introduction. London: Blakcwell, 1999.

Diani, M. “The concept of social movement.” Sociological Review, 1992: 1-25.

Diani, M. and Alberto Melucci. "Searching for Autonomy: The Sociology of Social Movements in Italy." Social Science Information, 1988: 333-53.

Dolan, Ronald E. Philippines: A Country Study. Library of Congress, 1991.

Edelman, Marc. "Social movements: Changing paradigms and forms of politics." Annual Review of Anthropology , 2001: 285-315.

El Awaisi, A. The Muslim Brothers and the Palestine Question 1928-1947. Tauris Academic Studies, 1998.

Entelis, John P. Comparative Politics of North Africa: Algeria, Morocco and Tunisia. New York: Syracuse University Press, 1980.

Entelis, John P. State and Society in Algeria. Boulder: Westview Press, 1992.

Falah, Ghazi. "Arab versus Jew in Galiliee: Competition for Regional Resources.” GeoJournal, 1990: 325-336.

Fanon, Frantz. The Wretched of the Earth. New York: Grove Weidenfeld, 1963.

Farsoun, Samih, and Christina E. Zacharia. Palestine and the Palestinians. Boulder: Westview Press, 1997.

Foweraker, Joe. Theorizing Social Movements. London: Pluto Press, 1995.

Frake, C.O. "Abu Sayyaf: Displays of Violence and the Proliferation of Contested Identities among Philippine Muslims.” American Anthropologists, 1998: 41-54. 
Frake, Charles O. "Abu Sayyaf: Displays of Violence and the Proliferation of Contested Identities among Philippine Muslims." American Anthropologists, 1998: 41-54.

Front Islamique du Salut. Le FIS du peuple: Politiqu, droit et prison en Algerie. Front Islamique du Salut, 2003.

Gamson, WA and DS Meyer. Comparative Perspective on Social Movements. Cambridge: Cambridge University Press, 1996.

Garner, Roberta. "50 Years of Social Movement Theory.” In Soccial Movement Theory and Research, an Annotated Bibliography. Salem: Scarecrow Press,1997.

Gillespie, Joan. Algeria: Rebellion and Revolution. New York: Praeger, 1960.

Giuigni, Marco G. "Was it woth the effort? The Outcomes and Consequences of Social Movements.” Annual Review of Sociology, 1998: 371-393.

Goodwin, Jeff, James M. Jasper and Jaswidner Khattra. "Caught in a Winding, Snarling Vine: The Structural Bias of Political Process Theory.” Sological Forum, Vol. 14, No. 1 Mar., 1999: 27-54.

Gurr T. Why men rebel. New Jersey: Princeton University Press 1970.

Gutierrez, Eric and Saturnino Borras, Jr. "The Moro Conflict: Landlessness and Misdirected State Policies.” The East West Center. Washington, D.C, 2004: 1-89.

Haidar, A. Social Welfare Services for Israel's Arab Population. Boulder: Westview Press, 1991.

Halstead, J. Mark and Affouneh, Saida Jaser. "Educating the human spirit in times of conflict: the case of emergency education in Palestine." International Journal of Children's Spirituality, 2006: 199-215.

Harik, Judith Palmer. Hezbollah: The Changing Face of Terrorism. New York: I.B. Tauris \& Co., 2004.

Hatina, Meir. Islam and Salvation in Palestine. Tel Aviv: Tel Aviv University, 2001.

Herman, Didi. "Reforming Rights: Reforming rights: Lesbian and Gay Struglle for Legal Equality in Canada.” PhD dissertation. UK: University of Warwick, 1992.

Hijjeh, Shahir. TWG Report on the Economics of Biodiversity. Unpublished report to Palestinian Environmental Affairs, 1998.

Hogg, Michael A., and Deborah J. Terry. "Social Identity and Self-Categorization Processes in Organizational Contexts." The Academy of Management Review, 2000: 121-140.

Hroub, K. Hamas: Political Thought and Practice. Washignton DC: Institute of Palestine Studies, 2000.

Hugh, Roberts. "Perspectives on Berber Politics: On Gellner, and Masqueray, or Durkheim;s Mistake." The Journal of Royal Anthropological Institute, 2002: 107-126.

International Crisis Group. "Algeria: Unrest and Impasse in Kabylia." Middle East and North Africa Report No. 15, 2003: 1-48.

International Crisis Group. "Islamism, Violence and Reform in Algeria: Turning the Page." Middle East Report No 29, 2004: 1-29.

International Crisis Group. “The Civil concord: A Peace Initiative Wasted.” Africa Report No. 31, 2001.

International Crisis Group. “Diminishing Returns: Algeria’s 2002 Legislative Elections.” Middle East/North Africa Briefing, 2002.

International Crisis Group. “Algeria: Unrest and Impasse in Kabylia.” Middle East North Africa Briefing, 2003. 
International Crisis Group. "Palestinians, Israel, and the Quartet: Pulling Back From the Brink." Crisis Group Middle East Report, 2006: 1-48.

Jacobson, Mathew. "Legitimization and the Discursive (Re)production of Socail Domination: Case Study of British Political Dsicourse and the Israeli Occupation of Palestine." Atheinea Digital, 2007: 34-55.

Johnston, Brian. "Seeing Palestine Through the Architecture of Domination." Washington Report on Middle East Affiars, 2008.

Joppke, Christian. "Social Movements During Cycles of Issue Attention: The Decline of Antinuclear Movements in West Germany and the USA." The British Journal of Sociology, 1991: 43-60.

Keck, M and K. Sikkink. Activists Beyond Borders. Ithaca: Cornell University Press, 1998.

Kerkvliet, Benedict J. "Review: Critique of the Rand Study on the Philippines." The Journal of Asian Studies, 1973: 489-500.

Khalidi, Rashid. Palestinian Identity: The Construction of Modern National Consciousness. New York: Columbia University Press, 1997.

Khawaja, Marwan. "Repression and Popular Collective Action: Evidence From the West Bank.” Sociological Forum, 1993: 47-71.

Khawaja, Marwan. "Resource Mobilization, Hardship and Popular Collective Action in the West Bank.” Social Forces, 1994: 191-220.

King, Gary, Robert O. Keohane, and Sydney. Verba. Designing Social Inquiry: Scientific Inference in Qualitative Research. Princeton, NJ: Princeton University Press, 1994.

Klandermans, Bruce. International Social Movement Research: Organizing for Change : Social Movement Organizations in Europe and the United States (International Social Movement Research). JAI Press, 1989.

Knauss, Peter R. The Persistence of Patriarchy: Class, Gender, and Ideology in Twentieth Century Algeria. New York: Praeger Publishers, 1987.

Kuhlken, Robert. "Settin' the Woods on Fire: Rural Incendiarism as Protest." Geographical Review, 1999: 343-363.

Lapidus, Ira M. A History of Islamic Societies. Cambridge: Cambridge University Press, 2002.

Layachi, Azzedine and Abdel-Kader Hairechce. "National Development and political protest: Islamists in the Maghreb Coutnries." Arab Studies Quarterly, 2001: 69.

Legrin, Jean-Francis. "The Islamic Movement and the Intifada." In Intifada: Palestine at the Crossroads, by J. and Roger Heacock Nassar. New York: Praeger, 1990.

Levitt, Matthew. Hamas: Politics, Charity and Terrorism in the Service of Jihad. Harrisonburg: The Washingont Institute for Mear East Peace, 2006.

Lofland J. Protest: studies of collective behavior and social movements. New Brunswick: Transaction Books, 1985.

Machado, K.G. "From Traditional Faction to Machine: Changing Patterns of Political Leadership and Organization in the Rural Philippines." The Journal of Asian Studies, 1974: 523-547.

Magdalena, Federico V. "Intergroup Conflict in the Southern Philippines: An Empirical Analysis.” Journal of Peace Research, 1977: 299-313.

Majul, Cesar Adib. Muslims in the Philippines: A Hsitorical Perspective. Philippines: University of the Philippines Press, 1999.

Marzouq, I., interview by Rachael Rudolph. The Role of PIJ, July 15, 2007. 
McAdam, Doug. "Political Opportunities: Conceptual Origins, current problems, future deceisions.” In Doug McAdam, John D. MCCarthy, eds. Compartive Perspectives on Social Movements, Cambridge: Cambridge Universoty Press, 1996.

McCarthy, John D. and Mayer N. Zald. "Resource Mobilization and Social Movements." American Journal of Sociology, 1977: 1212-1239.

McCormack, Thelma H. "The Motivation of Radicals." The American Journal of Sociology, 1950: 17-24.

McKenna, Thomas. Muslim Rulers and Rebels: Everyday Politics and Armed Separatism in the Southern Philippines. Berkeley: University of California Press, 1998.

Melucci, Alberto. Nomads of the Present: Social Movements and Individual Needs in Contemporary Society, edited by John Keane and Paul Mier, London: Hutchinson Radius, 1989.

Melucci, Alberto. "The New Social Movements: A Theoretical Approach." Social Sciences Information, 1980: 199-226.

Melucci, Alberto. "The Symbolic Challenge of Contemporary Movements?" Social Research 52:4, 1985: 789-816.

Meyer, David S. “Tending the Vineyard: Cultivating Political Process Research.” Sociological Forum, 1999

Mishal, Sahul, and Avraham Sela. The Palestinian Hamas. New York: Columbia University Press, 2000.

Montesano, Michael J. "The Philippines in 2002: Playing Politics, Facing Deficits and Embracing Unlce Sam." Asian Survey, 2003: 156-166.

Moore, Dahlia and Salem Aweiss. Bridges Over Troubled Water: A Comparative Study of Jews, Arabs and Palestinians. London: Praeger, 2002.

Mounshipouri, Mahmood. "Reorm and the Human Rights Quandry: Islamists versus Secularists." Journal of Chruch and State, 1998: 445-474.

Nasser-Najjab, Nadia. "Palestinian Political Movements: Should They Be Registered." Palestine-Israel Journal, 2005.

Navaneetham, Kannan. "Age Structural Transition and Economic Growth: Evidences from South and SouthEast Asia.” Asian MetaCentre Research Paper Series, 2008.

Novati, Giampaolo Calchi and Stefano Belluci. "Islamic Governance in Algeria and Sudan: A Fading Quest for a Model?" Mediterranean Quarterly, 2001: 100-114.

Olson, Mancur. The Logic of Collective Action. Cambridge: Harvard University Press, 1965.

Polletta, Francesca and James Jasper. "Collective Identity and Social Movements.” Annual Review of Sociology, 2001.

Reudy, John. Modern Algeria: The Origins and Development of a Nation. Second Edition. Bloomington: Indiana University Press, 2005.

Reuveny, Rafael. "The Political Economy of Israeli-Palestinian Interdpendence." Policy Studies Journal, 1999.

Roberts, H. “Algeria's Ruinous Impasse and the Honorable Way Out.” International Affairs, 1995: 247-67.

Rochon, Thomas R. "Review: Political Movements and State Authority in Liberal Democracies." World Politics, 1990: 299-313.

Rosenfeld, Maya. Confronting the Occupation: Work, Education, and Political Activism of Palestinian Families in a Refugee Camp. Stanford: Standford University Press, 2004. 
Rudolph, Rachael M. and Anisseh Van Engeland. From Terrorism to Politics. London: Ashgate Publishing, 2008.

Ruland, Jurgen. "Constitutional Debates in the Philippines: From Presidentialism to Parliamentarianism.” Asian Survey, 2003: 461-484.

Salamat, Hashim. The Bangsa Moro People's Struggle Against Oppression and Colonialism. Camp Abubakre As-Siddique: Agency for Youth Affairs-MILF, 2001.

Saleh, Moshen. "Hassan al-Banna's Centenary....Attitude towards Palestinian Cause." Ikhwanweb. 2006. http://www.ikhwanweb.com (accessed May 25, 2007).

Schirmer, Daniel B. and Shalom, Stephen R. The Philippines Reader: A History of Colonialism, Neocolonialism, Dictatorship, and Resistance. Boston: South End Press, 1987.

Schnell, I. Perceptions of Israeli Arabs: Territoriality and Identity. Avenbury: Aldershot, 1994.

Semsek, Sefa. "New Social Movements in Turkey Since 1980.” The Journal of Turkish Studies, 2004.

Shabaneh, Luay. "Jerusalem's Economic Shift and the Gap Between the City's Arabs and Jews." Palestine-Israel Journal, 2007: 103-107.

Shahak, Israeli. "Israeli Land Seizure in the Occupied Territories." Middle East Policy, 1992: 96106.

Shahak, Israeli. "The Religious Settlers: An Inestment of Israeli domination." Middle East Policy, 1994: 44-56.

Shallah, Ramadan Dr. "Islamic Jihad Leader explains his call for "armed struggle"." British Broadcasting Corporation, October 30, 1999.

Silverstein, Paul A. "An Excess of Truth: Violence, Conspiracy Theorizing and the Algeian Civil War." Anthropological Quarterly, 2002: 643-674.

Smelser, Neil J. Theory of Collective Behavior. London: Routledge and Paul, 1959.

Soffer, A. and R. Finkel. The Observation outposts in the Galilee: goals, achievements, conclusions. Rehovot, The Center for the Study of Rural and Urban Settlement, 1989.

Steinberg, David Joel. The Philippines: A Singular and a Plural Place. Cambridge: Westview Press, 1994.

Tahi, Mohand Salah. "Algeria's democratization process: a frustrated hope." Third World Quarterly, 1999: 197-220.

Taraki, Lisa. "The Development of Political Consciousness Among Palestinians in the Occupied Territories,” in Nassar, Jamar and Roger Heacock. Intifada: Palestine at the Cross Roads. London: Praeger, 1990.

Tarrow, Sydney. Power in Movement. Cambridge: Cambridge University Press, 1994.

Thapa, Shanker. "Caste and Social Domination." Ancient Nepal. April-May 1988. http://www.digitalhimalaya.com/collections/journals/ancientnepal/nonjavascript.php (accessed May 15, 2008).

Thompson, Mark R. "Off the Endangered List: Philippine Democratization in Comparative Perspective.” Comparative Politics, 1996: 179-205.

Tilly, Charles. From Mobilization to Revolution. Reading: Addison-Wesley, 1978.

Touraine, Alain. Return of the Actor: Social Theory in Postindustrial Society, translated by Myma Godzich, Minneapolis: University of Minnesota Press,1988.

Vahabzadeh, Peyman. "A Critique of Ultimate Referentiality in the New Social Movement Theory of Alberto Melucci.” Canadian Journal of Sociology. Autumn 2001: 611-633.

Vasi, Ion Bogdan. “The New Anti-war Protests and Miscible Mobilizations.” Social Movement Studies, 2006: 117-136. 
Weekley, Kathleen. "Nation and Identity at the Centennial of Philippine Independence." Asian Studies Review, 1999: 307-353.

Williamson, Jeffrey G. "Dimensions of Postwar Philippine Economic Progress." The Quarterly Journal of Economics, 1969: 93-109.

Williamson, Jeffrey G. "Dimensions of Postwar Philippine Economic Progress.” The Quarterly Journal of Economics, 1969: 93-109.

Yiftachel, Oren. "The Political Geography of Ethnic Protest: Nationalism, Deprivation and Regionalism among Arabs in Israel," Transactions of the Institute of British Geographers, 1997: 91-110.

Zald, M. and R. Ash. "Social Movement Organizations.: Growth, Decay and Change.” Social Forces, 1996: 327-340.

Zoubir, Yahia H. "Algerian Islamists' conception of democracy." Arab Studies Quarterly, 1996. 
Curriculum Vitae

\section{Rachael M. Rudolph}

Academic Affiliations:

Assistant Professor

Emory \& Henry

PO BOX 947

Emory, VA 24327-0947
Home/Permanent Address:

PO BOX 21

Spring Gap, Maryland 21560

Phone: (301) 268-2451

Email: rachaelrudolph@mindspring.com

\section{EDUCATION}

Doctorate of Philosophy, West Virginia University, Department of Political Science.

Dissertation: "Mobilizing Movements, Mobilizing Islamic Resistance”

Master of Arts in International Affairs, (2006) American University, School of International Service. Thesis title: "Identity, Foreign Policy and the War on Terrorism in Saudi Arabia."

Bachelors of Science, (2002) Frostburg State University, Department of Political Science. Graduated with Departmental honors.

Certificate, (2002-2003) Graduate School of Islamic and Social Sciences, Arabic Program (Intermediate).

Certificate, (2002) School of Advanced International Studies, Johns Hopkins University, Summer Language Institute (Basic Arabic).

\section{CONTINUING EDUCATION COURSES}

Women and Islam, (Completed May 2007), Witness Pioneer Virtual School.

International and Inter-Faith Relations (Completed October 2007), Witness Pioneer Virtual

School

Usul al-Fiqh Expected Completion Summer 2008), Witness Pioneer

\section{CONSULTING}

Gearson Lehrman Group: Leading international private consulting firm for which I am responsible for consulting on a contractual basis in the areas of Middle East foreign policy, security policy, and Islam and Islamic jurisprudence. 


\section{BOOKS}

From Terrorism to Politics, Ashgate Publishers, UK (2008) Co-author Anisseh Van Engeland Nourai. This book examines groups globally that utilize violence for the purpose of attaining a political end and make the transition to a political party. The first part of the book examines groups who have made the successful transition; the second section examines those who are in the process of making the transition; and, the last section, examines those who either have failed or are incapable of making the transition.

A History of Saudi Counter-Terrorism Policy: From 1929-2003 (Forthcoming 9/2008).

\section{FORTHCOMING BOOK PROJECT}

Men of Resistance: This project came to fruition this summer (2007), while conducting dissertation research. It seeks to examine the personal lives of men who were actively involved in Palestinian Resistance.

\section{ARTICLES IN PROGRESS}

"Measuring Power Relations in Networks of Violence." Article utilizes network analysis to design a measure of power relations for non-state actors.

“Transnationalizing the Fight Against Apartheid: The Case of Stop the Wall Campaign in Palestine.” This article is a product of my interviews conducted in Palestine in summer 2007 with Campaign organizers.

\section{MANUSCRIPT REVIEWS}

Articles pertaining to Saudi Arabia for The Journal for Third World Studies

\section{CONFERENCE PAPERS}

“Islamic Jihad: A Wild Card in Palestinian Politics?,” 2007 Middle East and Central Asia Conference, September 6-8, 2007, Salt Lake City, Utah.

"From Liberation to Terrorism to Politics: The Case of Hezbollah,” West Virginia Political Science Association October, 2006.

“The Pendulum of Legitimacy: Legitimacy of Political Violence,” 2006 Middle East and Central Asia Conference, September 8-10, 2006, Salt Lake City, Utah.

With Kyle M. Christensen. “US-Iran Peace Plan,” 2006 Middle East and Central Asia Conference, September 8-10, 2006, Salt Lake City, Utah. 
"The Politics of Identity in the Iranian Environment: Competing Norms, the Cross-fertilization of Religious and Secular Identities and the Evolution of Energy Policy,” August 4-7, 2006, London. Served as Chair and Discussant.

"Hamas: Liberation Organization to Political Party," The Second Arab World Congress, June 11-16 2006, Amman, Jordan.

“GW’s Iran: The Role of Presidential Beliefs in Foreign Policy Making,” January 4-7, 2006 Southern Political Science Association, Atlanta, Georgia.

“Palestinian Identity, Culture and Martyrdom,” 2005 Middle East Studies Association, November 19-22, 2005, Washington D.C.

With Greg Noone, Ismail Ahmadi and Kyle Christensen. Roundtable Discussion: "Rethinking the Middle East and Central Asia: Issues of Foreign Policy and Terrorism.” West Virginia Political Science Association, October 28-29, 2005.

With Ismail Ahmadi and Kyle Christensen. "The Discursive War of Words between Iran and the United States,” 2005 US-Iran Relations Conference, September 8-10, 2005, Salt Lake City, Utah.

“The Cross-fertilization of Martyrdom and the Construction of Martyrdom,” 2005 Middle East and Central Asia Conference, September 8-10, 2005, Salt Lake City, Utah.

"Voices of Violence in Iraqi-Kurdistan,” 2004 Middle East and Central Asia Conference, September 8-11, 2004, Salt Lake City, Utah.

With Greg Noone, Ismael Ahmadi, Kyle Christensen and Ibrahim al-Nahas. Roundtable discussion on Middle East Politics, West Virginia Political Science Association, October 22-23, 2004. Individual topic: Islamic Militant Groups in Northern Iraq.

“Islam, Wahhabism and Saudi Arabia,” March 2004, Frostburg State University.

“Identity and Foreign Policy in Saudi Arabia,” 2003 Middle East and Central Asia Conference, October 10-12, 2003, Salt Lake City, Utah.

“Voices of Violence in Saudi Arabia,” May 2003, Frostburg State University.

\section{$\underline{\text { TEACHING }}$}

- Fall 2008, Islamic Law (Sunni Schools of Islamic Jurisprudence), Emory \& Henry

- Fall 2008, Islamic Culture and Civilization, Emory \& Henry

- Fall 2008, Middle East Foreign Policy, Emory \& Henry

- Fall 2005 to Present, Introduction to Comparative Politics, West Virginia University.

- Summer 2006 to Present, Politics of Terrorism, West Virginia University. 
- Fall 2007, Global Political Issues, West Virginia University.

\section{TEACHING AWARDS}

Eberly College of Arts and Sciences 2006-7 Outstanding Graduate Teaching Award, West Virginia University

Department of Political Science 2006-7 Outstanding Graduate Teaching Award., West Virginia University

\section{METHOLOGICAL CAPABILITIES AND INETERESTS}

Capable in Basic Research Methods (qualitative and quantitative)

Currently using Network and Cluster Analysis in forthcoming journal articles.

Interested and capable in advanced methods such as structural equation modeling, social network analysis (SNA), organization network analysis (ONA), and cluster analysis.

\section{INVITATIONAL LECTURES}

Frostburg State University, October 2006

Frostburg State University, October 2005

\section{RESEARCH INTERESTS}

- Foreign Policy (Theories of Islamic Foreign Policy and Foreign Policies in the Middle East)

- Terrorism (Middle East and groups which utilize Islamic discourse)

- Islamic Jurisprudence (Hanbali, Hanafi, Sha'fi and Maliki)

- Islamic Political Movements and Political Islam (Middle East and Central Asia)

- International Relations Theory

- Political Theory and Philosophy:

Political Thought (Modern Islamic).

Politics of Dissent.

- Regional Specialty: the Gulf States, in particular Saudi Arabia, Kuwait, Iraq (including Kurdistan) and Iran.

\section{PROFESSIONAL EMPLOYMENT}

- Assistant Professor, Emory \& Henry (2008-Present)

- Instructor, West Virginia University (2005-Present)

- Research Assistant, West Virginia University (2005).

- Legal Researcher, Law Office of Kathleen M. Callan and Michael Krautner (2005). 
- Acting Executive Director, Allegany Law Foundation. (2004).

- Project Coordinator, (2003-2004) Allegany Law Foundation (2003-2004).

- Paralegal/Legal Researcher, Allegany Law Foundation (2000-2004).

\section{LANGUAGES}

- Arabic (reading and writing, intermediate)

- Spanish (reading, intermediate)

- French (reading, intermediate)

- Italian (reading, intermediate) 